\title{
Dynamics of pastoral traditional ecological knowledge: a global state-of- the-art review
}

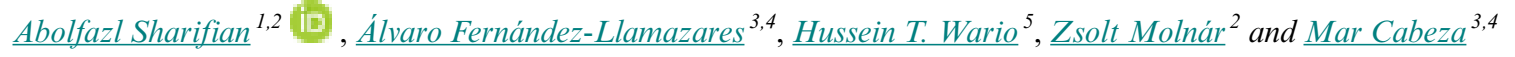

\begin{abstract}
Traditional ecological knowledge enables pastoralists to cope with social-ecological changes, thereby increasing the sustainability of their practices and fostering social-ecological resilience. Yet, there is a significant knowledge gap concerning the extent to which pastoral traditional ecological knowledge has changed over time at the global level. We aim to fill this gap through a systematic literature review of 288 scientific studies on pastoral traditional ecological knowledge. We reviewed 152 papers in detail (selected randomly from the 288) for their content, and focused specifically on 61 papers that explicitly mentioned one of the four types of knowledge transition (i.e., retention, erosion, adaptation, or hybridization). Studies on pastoral traditional knowledge represent less than $3 \%$ of all the scholarly literature on traditional ecological knowledge. Geographical distribution of the 288 case studies was largely biased. Knowledge domains of pastoral knowledge such as herd and livestock management, forage and medicinal plants, and landscape and wildlife were relatively equally covered; however, climate-related knowledge was less often studied. Of the 63 papers that explicitly mentioned transition of pastoral traditional ecological knowledge, 52 reported erosion, and only 11 studies documented explicitly knowledge retention, adaptation, or hybridization of traditional knowledge. Thus, adaptation and hybridization was understudied, although some case studies showed that adaptation and hybridization of knowledge can efficiently help pastoralists navigate among social-ecological changes. Based on the review, we found 13 drivers which were mentioned as the main reasons for knowledge transition among which social-cultural changes, formal schooling, abandonment of pastoral activities, and transition to a market economy were most often reported. We conclude that future research should focus more on the diverse dynamics of pastoral traditional knowledge, be more careful in distinguishing the four knowledge transition types, and analyze how changes in knowledge impact change in pastoral practices and lifestyles. Understanding these phenomena could help pastoralists' adaptations and support their stewardship of their rangeland ecosystems and biocultural diversity.
\end{abstract}

Key Words: Indigenous knowledge; pastoralism; rangelands; social-ecological systems; transition; transmission

\section{INTRODUCTION}

Since the 1992 Rio Earth Summit, the importance of traditional ecological knowledge (TEK) in the conservation of biological and cultural diversity has been increasingly acknowledged by both the scientific community and policy-makers around the globe (Maxted et al. 2002). TEK plays a vital role in the livelihoods of rural communities and the sustainable management and use of natural resources by Indigenous peoples and local communities (Olsson and Folke 2001). Opinions about TEK, previously rife with negative characteristics such as being static and archaic, are now appreciating the dynamic nature of this knowledge and related practices. An increasing number of studies involving traditional farmers (Cristancho and Vining 2009, McCarter and Gavin 2014) and hunter-gatherers (Fernández-Llamazares et al. 2015, Gallois et al. 2015) have shown nonadaptive changes in TEK, mostly loss of TEK due to changes in intergenerational transmission mechanisms or other drivers (Srithi et al. 2009, Reyes-García et al. 2013). But despite a myriad of cultural pressures, many aspects of TEK systems are resilient. There is mounting evidence that TEK is adaptive to changes in the environment and is fluid with social-economic and cultural changes (Berkes et al. 2000, McCarter et al. 2014). Thus, not all changes in Indigenous and local knowledge systems should be labeled as knowledge loss as long as loss of knowledge is not accidental and does not impair the efficient functioning of the practice. Thus, changes should often be evaluated from an adaptation perspective (Jandreau and Berkes 2016).

Dynamic adaptation of knowledge requires transmission between and within generations; otherwise, erosion or maladaptation of TEK is inexorable (Cavalli-Sforza et al. 1982, Turner et al. 2000). Changes or transitions in TEK, thus, can arise from changes in knowledge transmission processes and mechanisms but also from changes in the social, economic, and environmental systems that also affect knowledge needs; i.e., what knowledge is regarded as relevant and adaptive (Salpeteur et al. 2016). If the flora of a place becomes decimated, the community will know fewer flora elements than previous generations but will retain what becomes relevant (Duenn et al. 2017); in a system where technology is adopted and natural conditions manipulated, less awareness or knowledge about climate signs is adaptive too (Nkuba et al. 2019). Yet in a system where rapid changes affect social structures, and the needed knowledge for practicing the livelihood becomes impaired by lack of knowledge transmission, knowledge loss becomes nonadaptive (Srithi et al. 2009).

While TEK and TEK changes for Indigenous peoples and local communities are increasingly the subject of studies, the status of and trends in TEK for pastoral Indigenous peoples and local

\footnotetext{
${ }^{1}$ Department of Rangeland and Watershed Management, Gorgan University of Agricultural Sciences and Natural Resources, Gorgan, Iran, ${ }^{2}$ Centre for Ecological Research, Institute of Ecology and Botany, 2163 Vácrátót, Hungary, ${ }^{3}$ Helsinki Institute of Sustainability Science (HELSUS), Faculty of Biological and Environmental Sciences, University of Helsinki, FI-00014, Helsinki, Finland, ${ }^{4}$ Global Change and Conservation Lab, Organismal and Evolutionary Research Program, Faculty of Biological and Environmental Sciences, University of Helsinki, FI-00014, Helsinki, Finland, ${ }^{5}$ Center for Research and Development, Drylands, Kenya
} 
communities seems to have received less attention than that of other groups, while the relevance of pastoralism globally remains undeniable (Johnsen et al. 2019). These knowledge gaps and the urgency of their study are highlighted through the planned 2026 International Year of Rangelands and Pastoralists declared by the United Nations, which has announced the intention to address Indigenous knowledge and culture of pastoral communities (Kelly 2020). Globally, pastoralists are reported to number from 250 to 500 million people (McGahey et al. 2014, Johnsen et al. 2019). Relying on their TEK, pastoralists across the globe have been able to produce livestock in often unpredictable and highly variable conditions of rangelands that range from deserts to steppes, tundras, savannah, and mountainous areas (Stolton et al. 2019). This lifestyle is the result of close and intimate interrelations between people and nature, which lead to the formation of rich and complex bodies of knowledge, practice, and beliefs (Farooquee and Nautiyal 1999, Fernández-Giménez 2000, Molnár 2017). Many pastoralists are encountering rapid and fundamental changes in climate, the frequency of droughts and floods, the market economy, forage and fodder availability, social-cultural systems, and land use rights, but importantly, also regulations and policies that limit some of their practices and affect processes needed for the generation and transmission of TEK (Galvin 2009, Reid et al. 2014, Herrero et al. 2016, Belayneh and Tessema 2017). Such changes are leading to notable transitions in pastoral TEK (Bussmann et al. 2018, Hedges et al. 2020).

Pastoral TEK is not only essential for its role in improving the functionality of rangeland ecosystems (Shen et al. 2019), biological diversity (e.g., productive local livestock breeds that are tolerant of unique environments) (Hoffmann et al. 2014), sustainable management (conservation values of territories and their flora and fauna) (Fynn et al. 2016), and social and cultural preservation (e.g., 22 intangible cultural heritage items on the UNESCO list) (Stolton et al. 2019), but also for enhancing the social-ecological resilience and adaptability of pastoral communities to the challenges caused by diverse global changes (Oteros-Rozas et al. 2013, Yacoub 2018). Pastoral TEK contains several domains such as herd management; forage, fodder, and medicinal values of plant species; weather forecasting; and management of spatiotemporal heterogeneity of natural resources. Hence, lack of knowledge transmission or any negative change in different knowledge domains of pastoral TEK can cause irreversible effects on pastoral systems and their sustainability (Jandreau and Berkes 2016). Pastoral knowledge and practices are context-based and locally grounded, evolving and adapting to specific social-ecological conditions. However, this knowledge is regionally manifested and globally relevant (Brondízio et al. 2021), and has elements in common across pastoral systems. A recently published Scientists' Warning to Humanity on threats to Indigenous and local knowledge systems raises the importance of globally assessing the status of and trends in TEK systems (Fernández-Llamazares et al. 2021), and highlights how common global patterns are similarly affecting locally adapted knowledge systems. Such assessments are largely missing in the context of pastoralism, and few efforts have cut across disciplinary topics or regions (see Manzano-Baena et al. 2021 for a discussion).
We aim to synthesize the state of the art of knowledge on pastoral TEK and its dynamics, cutting across disciplinary topics and regions. To do so, we conducted a systematic review of scientific papers that dealt specifically with changes in pastoral TEK. To understand whether reported changes are viewed as adaptive, we focused on four types of TEK transition: retention, erosion, adaptation, and hybridization (see Theoretical Background for definitions). We addressed whether research is homogenous across knowledge domains (e.g., general ecological knowledge, knowledge on livestock management), and across main pastoral mobility types (sedentarism, transhumance, and nomadism) in search of regional or global patterns that could indicate drivers of change and threats to adaptive TEK dynamics.

\section{THEORETICAL BACKGROUND}

Prior to providing a definition for TEK, we defined Indigenous peoples and local communities as typically, ethnic groups who are descended from and identify with the original inhabitants of a given region who are dependent on nature for providing necessities of their livelihood in a sustainable way (IPBES 2019). TEK systems are cumulative bodies of knowledge, practices, and beliefs of Indigenous peoples and local communities that evolve by adaptive processes and are handed down through generations by cultural transmission (Berkes et al. 2000). We note that this definition is largely consistent with the one of "Indigenous and local knowledge systems" used by IPBES (2021), which defines these systems as "social and ecological knowledge, practices and beliefs pertaining to the relationship of living beings, including people, with one another and with their environment".

While pastoralism has multiple definitions and understandings, we focus on pastoral livelihoods that aim at raising domesticated and semidomesticated livestock within nature. This entails the movement of people and herds across landscapes, making use of natural vegetation and crop by-products. Pastoralism is about animals walking to their feed instead of having it grown, cut, and brought to them. In pastoral systems, animals are grazed and foraged in an extensive system instead of being stall-fed in an intensive system (Köhler-Rollefson 2020).

Four knowledge transitions were considered in this study. Retention is defined as the continuity and persistence of TEK without significant change in its quality and quantity; erosion is the decline or loss of TEK; adaptation is the transformation of TEK to adjust to changes in the environment and conditions; and hybridization is the integration of TEK into another knowledge system (Thomas and Twyman 2004, Zent 2013, FernándezLlamazares et al. 2021). While much research has focused largely on loss of pastoral knowledge (e.g., Hedges et al. 2020), many pastoral knowledge systems have also demonstrated resilience to social-ecological changes due to their inherently adaptive and dynamic nature (Galvin 2009). The adaptability and resilience of pastoral knowledge systems is evident in many ecosystems around the world, which bear evidence of pastoral practices over millennia (Jandreau and Berkes 2016, Ellis et al. 2021).

We acknowledge that changes in TEK ramify through complex pathways, and that causality flows in multiple directions and is often circular. TEK changes usually modify the ecosystems that are shaped by such systems, and then the opportunities for practicing TEK (as a local expression of culture) are constrained 
Table 1. Variables elicited and used for the review (TEK: traditional ecological knowledge).

\begin{tabular}{|c|c|c|}
\hline Variable & Description & $\begin{array}{c}\text { Number of } \\
\text { papers }\end{array}$ \\
\hline Year & Publication year & 152 \\
\hline Country & Place of the study & 288 \\
\hline $\begin{array}{l}\text { Pastoral system } \\
\text { type }\end{array}$ & Nomadism (nomad and semi-nomad); Transhumance (transhumant and semi-transhumant); Sedentarism (sedentary) & 152 \\
\hline Knowledge domain & $\begin{array}{l}\text { Herd/Livestock (subdomains: a. herd management; b. animal husbandry, veterinary); Forage/Medicine (subdomains: } \\
\text { a. Forage and fodder species; b. medicinal species); Landscape/Wildlife, etc. (subdomains: a. landscape and ecology; } \\
\text { b. wildlife; c. general biology); Climate (subdomain: a. weather and climate); Social-cultural (subdomains: a. social, } \\
\text { economic, and political aspects; b. culture and beliefs) }\end{array}$ & 152 \\
\hline TEK transition & Yes (TEK transition was mentioned); No (TEK transition was not mentioned) & 152 \\
\hline $\begin{array}{l}\text { Type of knowledge } \\
\text { transition }\end{array}$ & $\begin{array}{l}\text { Erosion (reduction of the knowledge was reported); Retention (no change was reported, and continuity was the state } \\
\text { of knowledge transition); Hybrid/integration (TEK integrated into another knowledge system; i.e., scientific } \\
\text { knowledge); Adaptation (new knowledge for adaptation exposed to environmental, climatic, political, cultural, and } \\
\text { economic changes); No report (there was no report that mentioned any transition) }\end{array}$ & 152 \\
\hline $\begin{array}{l}\text { Robustness of } \\
\text { reported transition }\end{array}$ & $\begin{array}{l}\text { Evidence-based (transition was evaluated based on an analysis of data gathered from a sample); Anecdotal } \\
\text { (transition was mentioned only in some pastoralists' quotes and was not based on analyzed results); Non-evidence } \\
\text { based (not based on data analysis or pastoralists' quotes, but simply mentioned by the authors). }\end{array}$ & 63 \\
\hline $\begin{array}{l}\text { Drivers of } \\
\text { knowledge } \\
\text { transition }\end{array}$ & $\begin{array}{l}\text { Causes of change in pastoral TEK. Drivers were identified based on direct sentences in the Results and Discussion } \\
\text { sections of the reviewed paper. Drivers were not predetermined, and they were added when a new driver was } \\
\text { identified in the paper. }\end{array}$ & 63 \\
\hline
\end{tabular}

by the new ecological trajectories (Lyver et al. 2019). As a result, the change itself, the cause of the change, and the consequences of that change are often linked and iterative (see Holling and Gunderson 2002). In short, pulling apart one thread in the cultural fabric of a given TEK system can lead to the unraveling of the social and ecological fabrics that have sustained pastoralists for centuries and millennia (Ford et al. 2020).

We also note from the outset that none of the authors are members of pastoralist communities, and that our review reflects a situated and partial interpretation of pastoral knowledge dynamics. However, we draw on several decades of in-depth field-based ethnographic experience among pastoral societies on several continents. While we see value in bringing into focus the global extent of pastoral TEK, we understand that a global review such as this one has the potential to obscure the very place-based nature of TEK and the rich diversity of pastoral cultures and knowledge systems (see Ford et al. 2016). By presenting real-world examples from all inhabited continents, we aim to emphasize the different place- and culture-specific ways in which pastoralists navigate changes in their knowledge systems

\section{METHODS}

The first step of the review process was to undertake a systematic literature search for peer-reviewed scientific articles about pastoral TEK using Web of Science. This search was carried out on 28 November 2019 and was guided by keywords that covered various phrases for both TEK and pastoralists which were selected and applied to find all available papers published in English regarding pastoral TEK. We used the following Boolean phrase to search not only the titles, but also the whole body of the papers:

TS = (("aborigin* knowledge" OR "traditional knowledge" OR "traditional local knowledge" OR "ecological knowledge" OR "traditional environmental knowledge" OR "Indigenous knowledge" OR "local knowledge" OR "folk knowledge") AND (pastoral* OR flock* OR herd* OR shepherd*)).
This led to the identification of 382 papers, from which 372 papers were traceable (Appendix 2). In the next step of the study, the title, Abstract, and Materials and Methods sections of all 372 papers were screened to omit papers unrelated to pastoral TEK. Thereby, 84 papers were eliminated in this phase. For instance, using keywords "flock" or "herd" with TEK-related keywords such as "local knowledge" led to some fishing-related TEK papers, which were disregarded at this phase. For the remaining 288 papers, we reviewed the types of TEK transition reported (especially adaptation and hybridization), and the countries where each study was conducted (Table A1.1).

In the third step, we proceeded to subsample papers for a more detailed, quantitative review. To do so, the 288 papers were sequentially numbered ( 1 to 288), and a random number generator was applied (using the "= RAND ()" function in Microsoft Excel 2019) to select the first approximately 102 papers, with a further addition of 50 more papers to assess the robustness of findings (Table A1.2). For these papers, we recorded the title, journal, DOI, and first author's name, and eight variables of interest: year of the study, the country where the study was conducted, pastoral system type, studied knowledge domain, mention of TEK transition, type of knowledge transition, robustness of reported transition, and drivers of knowledge transition (Table 1). Classification of papers as reporting knowledge transitions (and transition type) was done based on text mentions (in the Results and Discussion), not on our own interpretation of the paper's data. To check the robustness of reported transition type, three different states of evidence-based report of transition, anecdotal report of transition, and nonevidence-based report of transition were considered. Further explanation is provided in Table 1 . Since the relative frequency of the investigated variables was not significantly different between the primary studies (102) and the final set (152) $(p>0.05$; Table A1.3), the result was viewed as robust enough, so the remaining (136) papers were not inspected for this detailed quantitative analysis. 
We conducted an additional bibliographic search to compare the research attention given to TEK pastoralist studies in relation to all studies of TEK. We compared the outcomes of the pastoralism-related Boolean phrase to the outcomes of the following search query:

TS = ("aborigin* knowledge" OR "traditional knowledge" OR "traditional local knowledge" OR "ecological knowledge" OR "traditional environmental knowledge" OR "Indigenous knowledge" OR "local knowledge" OR "folk knowledge").

\section{Statistical analyses}

All analyses were conducted in R using Rstudio software [Version 1.2.5033]. Descriptive analysis and visualization were performed using ggplot2 and dplyr packages. The Wilcoxon rank sum test was used to assess the statistical significance of two-level variables (e.g., comparing the primary and final database), and the Kruskal-Wallis test was used for observed variables with more than two levels (i.e., pastoral system type) at a $95 \%$ confidence interval. Additionally, a global map of the frequency of studies published was produced using the rworldmap package. The final database with 19 columns and 152 rows and $\mathrm{R}$ scripts is appended as a supplementary file, including meta-data (Tables A1.1, A1.2, A1.3; CodeA1.1).

\section{RESULTS AND DISCUSSION}

\section{Pastoral traditional ecological knowledge studies are few and geographically biased}

The number of scientific studies on TEK in general showed an increasing trend over the last four decades, with a parallel trend for studies on pastoral TEK. Additionally, all studies reported that pastoralists carry valuable and deep knowledge regarding different aspects of their pastoral social-ecological systems. However, the proportion of TEK studies that focused on pastoral TEK was low: only $3 \%$ of all scientific studies on TEK (Fig. 1). Considering that $40 \%$ of the global land surface is used by pastoralists and that there are an estimated hundreds of millions of pastoralists (Zinsstag et al. 2006, McGahey et al. 2014), despite its extent, global representation, and heterogeneity, pastoral TEK remains less studied than other groups. These figures align closely with several reports and scholarly articles that argue that pastoralist systems have received scant policy and research attention to date (e.g., Johnsen et al. 2019, Manzano-Baena et al. 2021). Taking into account the global relevance of pastoralism, with its extent and the large number of people depending on the practice, this observation supports calls for bringing more attention to pastoral TEK concerns (Molnár 2014, FernándezGiménez 2000) that are in the agenda of the proposed International Year of Rangelands and Pastoralists for 2026. In line with our results, Brook and McLachlan (2008) showed that farmer and hunter-gatherer communities have received much more scholarly attention than other communities such as pastoralists. Additionally, the United Nations Environment Programme report on the number of studies on rangeland and pastoralism confirms that compared to other topics, research on rangelands and pastoralism is substantially lower $(96,414$ records from 71 million records), and that pastoral TEK studies account for only $1 \%$ of the total studies and projects on rangeland and pastoralism (Johnsen et al. 2019).
Fig. 1. Number of all traditional ecological knowledge (TEK) and pastoral TEK papers published from 1978 to 2019.

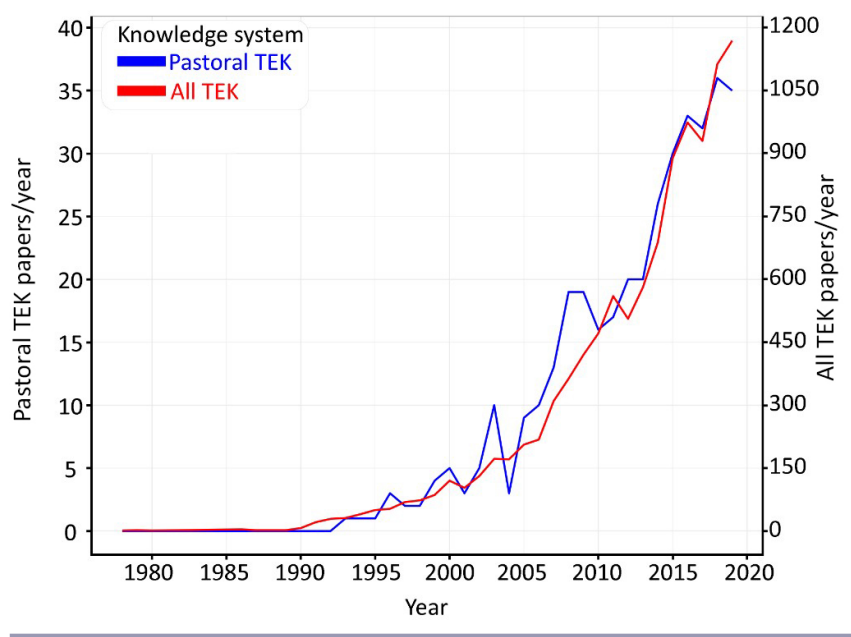

In terms of the geographical distribution of research on pastoral TEK (Fig. 2), most studies were conducted in Africa $(50 \%)$, followed by Asia (30\%), and Europe (14\%). Studies on pastoral TEK were scant in Oceania (3\%), South America (2\%), and North America (1\%). Overall, pastoral communities in 62 countries were studied, with Ethiopia (33 studies), Kenya (31), India (19), and China (18) being the most prominent ones.

Fig. 2. Number of pastoral traditional ecological knowledge studies per country based on the 288 papers reviewed.

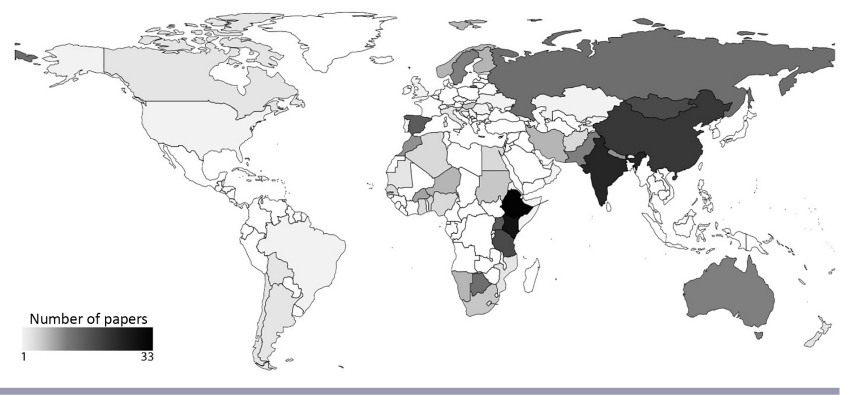

Aswani et al. (2018) and Hanazaki et al. (2013) also found that Ethiopia, India, and China were hotspots for TEK-related research. In the case of scientific studies on rangelands and pastoralism (as a whole), China, Mongolia, Australia, Kenya, and Ethiopia had the highest share of studies (Johnsen et al. 2019). Our results also showed that 20 countries were represented by only a single study. Noting that pastoral identities may vary within countries, with several Indigenous groups or ethnicities recognized in many countries, single studies are certainly not representative enough. For example, of the 42 recognized ethnic groups in Kenya (many of which practice some form of pastoralism; see, for example, LPP [2021]), only nine groups were included in more than one study. In another example, yak herding is practiced among at least 31 ethnic groups in the Asian highlands, yet only a few studies of some ethnic groups were available. In Buthan and Tajikistan, for instance, where together 
Fig. 3. Frequency of papers meeting review criteria by year considering traditional ecological knowledge (TEK) transition. (A) relative frequency of papers reporting TEK transition; (B) relative frequency of papers reporting different types of transition.

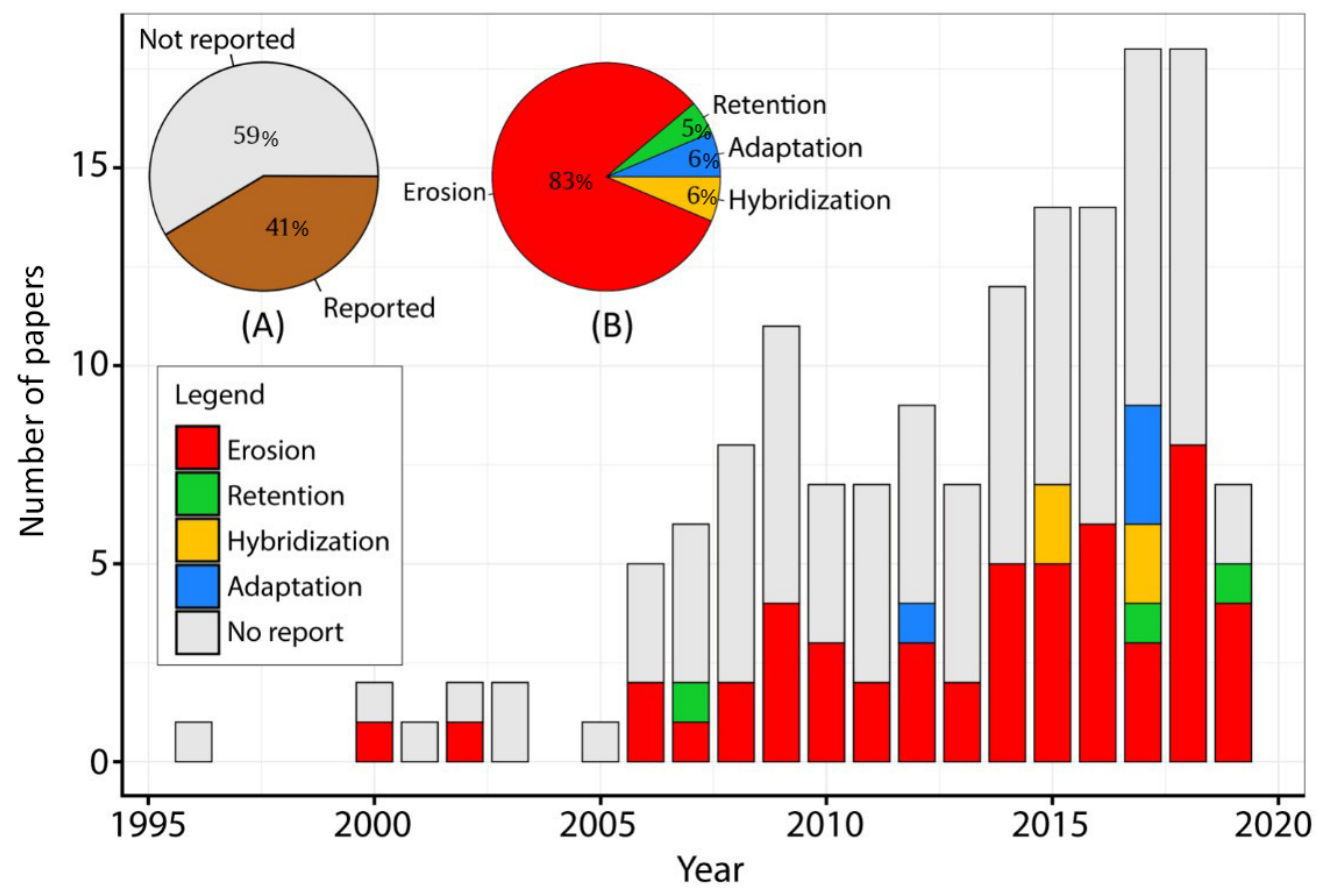

five ethnic groups are active in yak herding, only two general papers were found, and neither of them focused specifically on yak herding (Kassam 2009, Wu et al. 2014).

We found that some countries with large pastoral populations (e.g., Kazakhstan, Yemen, Somalia, and Uzbekistan) were not represented in the literature. This also extends to countries such as Central African Republic, Uruguay, or Eswatini, where more than $50 \%$ of the land is categorized as rangelands (Johnsen et al. 2019). This could be related to language barriers in science; much research written in French, Spanish, and Russian was not included in this study. We acknowledge that overlooking such literature can bias outcomes of evidence synthesis and lead to only a partial understanding of pastoralism at the global level.

\section{Knowledge domains and pastoral mobility types are unevenly studied}

Similar attention has been paid to five major TEK domains related to herd and livestock management knowledge, forage and medicinal plant knowledge, and knowledge of landscape and wildlife (i.e., 73, 75, 70 studies, respectively). Interestingly, despite growing research interest in pastoral vulnerability to climate change, pastoral TEK about climate has received relatively scant scholarly attention, with only 15 studies on climate-related knowledge domains. This knowledge is vital to vulnerability and adaptation assessment, and confronts policymakers with many research gaps (Ahearn et al. 2019). Pastoral TEK regarding climate and weather forecasting has enabled pastoralists to adjust their seasonal movement and cope with changes in precipitation and temperature, which dramatically affect the variability and availability of forage, fodder, and water sources (Nkuba et al. 2019). Also, the integration of climaterelated TEK, which is based on a variety of biological, cultural, and astrological indicators, with scientific forecasts could improve the accuracy, uptake, and application of weather forecasting by locals (Reyes-García et al. 2015, Radeny et al. 2019).

The papers reviewed often lacked information regarding the type of pastoral way of life and/or mobility systems. Of the $58 \%$ of papers that did provide information on mobility types, most focused on nomadic (56\%); fewer focused on transhumant $(32 \%)$ and sedentary $(25 \%)$ systems. When considering domains of knowledge and pastoralism types, it was less clear whether representativeness was even. It seems that ethnographic studies that addressed TEK tended to focus on groups that live more traditionally and have been less exposed to globalization; thus, this could reflect the greater attention paid to nomadic systems.

Transition in pastoral traditional ecological knowledge: erosion versus retention, adaptation, and hybridization

Transitions in pastoral TEK were addressed in $41 \%$ of the 152 papers reviewed in detail (Fig. 3A). Each of the four types of knowledge transition (i.e., retention, erosion, hybridization, and adaptation) was mentioned in at least one paper; erosion of knowledge was the transition type most often reported $(83 \%)$. Retention, hybridization, and adaptation were each mentioned in $6 \%$ or less of the papers (Fig. 3B). Of all the transitions reported, $35 \%$ were based on robust empirical evidence, $17 \%$ were anecdotal, and $48 \%$ relied on weak empirical footing, as no traceable form of evidence was provided in the paper. In general, the interest in studying transitions in pastoral TEK is growing in a similar way as the number of studies in pastoral TEK (Fig. 3). 
Fig. 4. Number of studies reporting traditional ecological knowledge transition types (based on 63 papers).

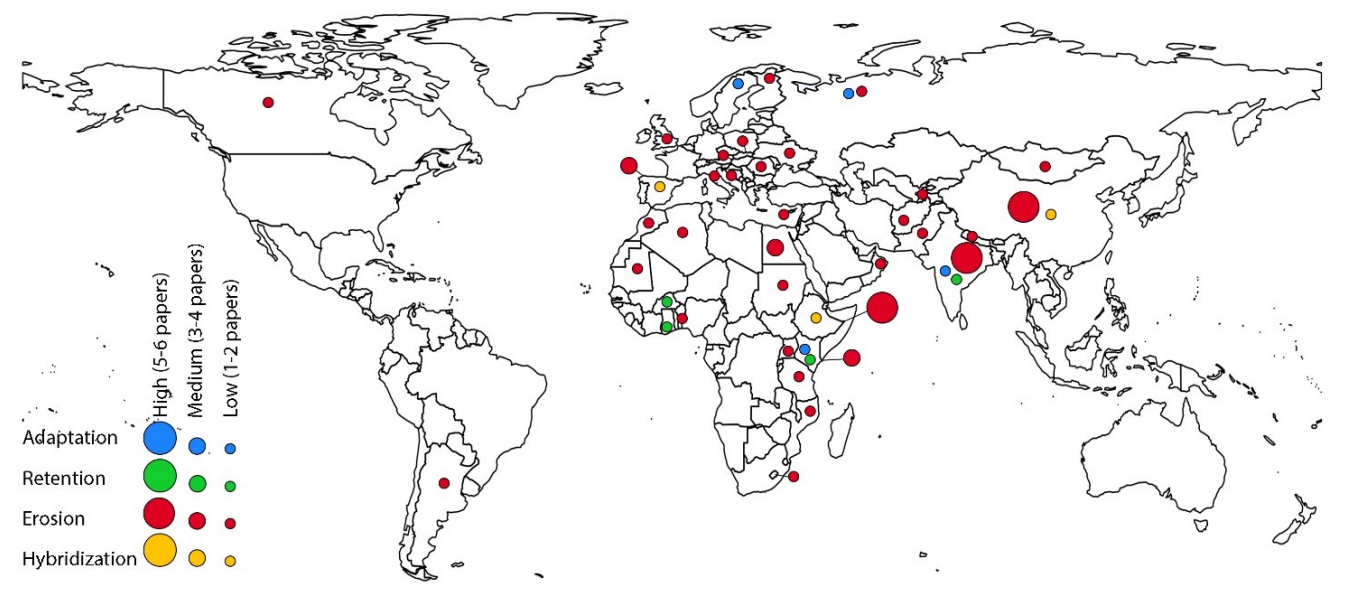

TEK erosion was commonplace globally but was most often reported in Asia and East Africa (Fig. 4). In Europe, Asia, and Africa, $55 \%, 53 \%$, and $31 \%$ of the total number of studies, respectively, reported some form of TEK transition. Reported transition showed Ethiopia, India, China, Kenya, Egypt, and Spain with more reports of erosion. Although comparing the status of TEK transition among countries is difficult because research effort is far from homogenous across countries, it is important to highlight that TEK erosion is reported in most of the studied countries, even in biologically and culturally diverse regions.

Knowledge erosion was reported in similar frequency for all five major knowledge domains. However, we found a greater relative frequency for the domains Herd/Livestock (42\%) and Forage/ Medicine (44\%) (Fig. 5). All domains reported at least 25\% for erosion of pastoral TEK. Without considering retention of TEK as a "change", the highest frequency for any type of TEK transition was reported for the Forage/Medicine (48\%) and Social-cultural (47\%) domains. Hybridization and adaptation were reported for only three knowledge domains each. The small number of available studies made it difficult to find robust global patterns.

From all the studies in which the type of pastoral system was mentioned, nomadic, transhumant, and sedentary systems $(45 \%$ [24 papers], 33\% [18 papers], and 22\% [12 papers], respectively) were mentioned to be affected by some form of TEK transition (Fig. 5). In all three pastoral system types, erosion was the most often reported transition, and in most cases, retention, adaptation, and hybridization was found only in a few cases. Further research is needed to obtain a better and more representative understanding of the differences in knowledge transitions across different pastoral mobility systems.

Regardless of the lifestyle that pastoralists have (nomadism, transhumance, or sedentarism), loss of unnecessary knowledge and accumulation of new knowledge occurs with time and new practices. In other words, if a community has a sedentary lifestyle, it does not mean that they have lower TEK compared to nomads (Nedelcheva et al. 2017). However, shifting from one lifestyle to another could affect the knowledge that pastoralists are "carrying" with themselves (Duenn et al. 2017, Bussmann et al. 2018). The slightly greater erosion of knowledge reported for transhumant and sedentary systems could suggest that some of these communities are increasingly shifting to sedentary lifestyles. Therefore, due to the shift, and at least regarding some knowledge domains that are less applicable in the new lifestyle, the volume of pastoral TEK may decline (Dong et al. 2011, Bussmann et al. 2018).

The relatively greater number of papers that reported pastoral TEK erosion may be alarming for local, national, and international organizations that are aiming to promote sustainable use of rangelands and biocultural conservation of pastoral social-ecological landscapes. Aswani et al. (2018) and Hanazaki et al. (2013) reported the same result when conducting reviews on TEK transition among other communities such as farmers, hunter-gatherers, and fishers, and found that $77 \%$ and $57 \%$ of the papers reviewed reported TEK erosion, respectively.

As pastoral communities are being impacted by changes in climate, culture, technology, social-economic conditions, and policies at various scales (Reid et al. 2014), so too are their TEK systems. On one hand, erosion of pastoral TEK could be the consequence of the change; on the other hand, it could be the very driver of the change. For example, recent changes in plant diversity in Eastern Africa have caused the extinction of some plant species that were used in weather forecasting and prediction by Borana pastoralists in southern Ethiopia and northern Kenya. This extinction has led to the erosion of knowledge about these plant species. Losing the knowledge of weather forecasting has affected pastoral migration and movement abilities, which consequently debilitates the Borana's resilience to climate change (Radeny et al. 2019).

Due to the low number of studies and the research gaps we identified, knowledge transition patterns found in this review cannot be considered indicative of what is happening to pastoral TEK globally. Importantly, not a single study addressed all types of knowledge domains or compared all types of pastoral mobility systems regarding knowledge transitions. Only one knowledge 
Fig. 5. A: Types of traditional ecological knowledge (TEK) transition reported for each major knowledge domain. B: TEK transition reported for different pastoral mobility types (black labels show percentages; red labels show the total number of papers).

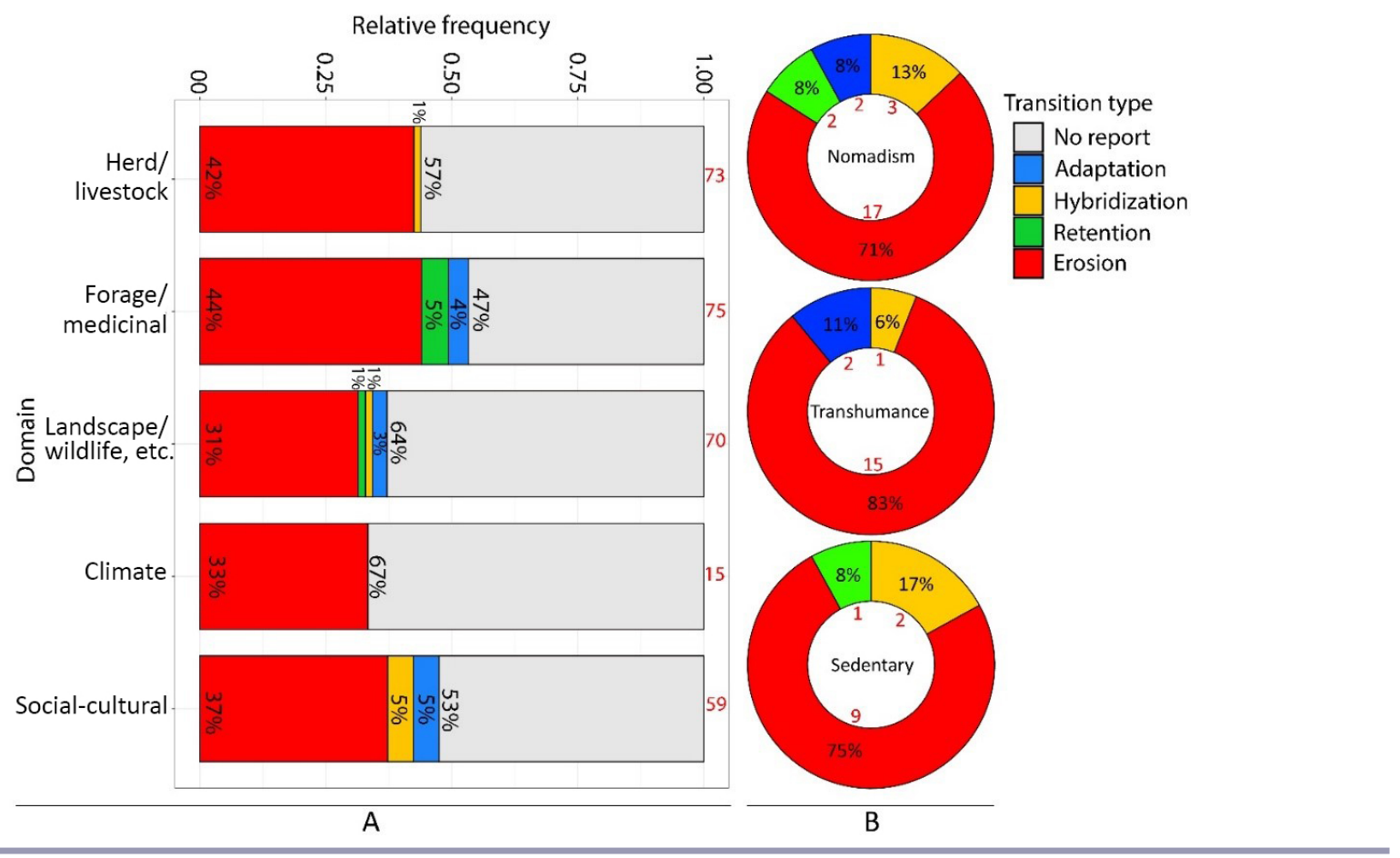

domain was covered in $49 \%$ of the studies, and only two were addressed in $37 \%$ of the studies. Also, regarding the subdomains (Table 1), $91 \%$ of studies focused on less than three subdomains, while approximately $2 \%$ of studies covered six subdomains: Oteros-Rozas et al. (2013), Fernández-Giménez (2015), and Jandreau and Berkes (2016).

Another research gap in pastoral TEK studies is that although different transitional types have been reported for pastoral TEK, most of the studies have labeled TEK transition as erosion. As it was also emphasized by Tian (2017), TEK transition is evaluated primarily linearly as gain or loss; however, adaptation and hybridization of TEK are also possible - and highly relevantchanges. Researchers have often assessed the transition of pastoral TEK by comparing the volume of knowledge between or within generations (Oteros-Rozas et al. 2013, Salpeteur et al. 2015) and have referred to the lower volume of knowledge of the younger generation as erosion. However, compared to the older generation, the new generation could be less knowledgeable, for instance, about plant species that used to be dominant in the region, while having gained more knowledge about a newly arrived invasive species (Duenn et al. 2017). In another case, changes in herd composition from cattle to sheep that are driven by market demands have resulted in the new generation having more knowledge about sheep but fading knowledge regarding cattle, which is no longer applicable based on the new circumstances (Adriansen 2008). We argue that erosion of TEK concerning specific subdomains should not automatically imply the overall downward trend in communities' TEK. In fact, this change may originate from adaptive strategies and/or hybridization of knowledge due to exposure to other knowledge systems.

Examples of adaptation, hybridization, and retention of pastoral traditional ecological knowledge

Adaptation, although rarely studied explicitly (only four studies, $6 \%$ of the sample), has been reported both in nomadic and transhumant systems (Fig. 5), and across several knowledge domains (i.e., Social-cultural, Forage/Medicine, and Landscape/ Wildlife). Yet, no adaptation has been reported for Herd/ Livestock and Climate knowledge domains. Knowledge adaptation among pastoralist societies is largely underrepresented in the scholarly literature, particularly so if we consider that pastoralism is a resilient and highly adaptive livelihood and the most widespread land use on Earth (Reid et al. 2014). Adaptive changes in pastoral practices (see, for example, Duenn et al. [2017]) deserve much more scholarly and policy attention than they have received to date. Similarly, hybridization has been poorly studied, but we found examples of hybridization across pastoral mobility types and some knowledge domains, though with no clear patterns. Knowledge retention was also mentioned in three studies. In one study, the new generation was found to carry greater knowledge regarding one domain compared to the elder generation (see Naah and Guuroh [2017] for more information). To illustrate differences between adaptation, hybridization, and retention, Table 2 presents some case studies.

\section{Major drivers of traditional ecological knowledge transition: pastoral knowledge is threatened}

Causality flows in multiple directions and is iterative: loss of TEK changes the ecosystems that were shaped by it, and the 
Table 2. Examples of adaptation and hybridization of pastoral traditional ecological knowledge (TEK) from different parts of the world.

\begin{tabular}{|c|c|}
\hline Type & Reference \\
\hline \multicolumn{2}{|l|}{$\begin{array}{l}\text { Adaptation: Pastoralists cope with changes in environment and social-economic conditions through adaptive strategies. Implementation } \\
\text { of new practices is based on adaptive knowledge that makes the adjustment of pastoral systems to changes effective. }\end{array}$} \\
\hline $\begin{array}{l}\text { Kenya: Due to diet changes among Maasai pastoralists, shifting from milk and meat centered to more agricultural crops, girls' activities } \\
\text { and TEK regarding firewood collection have expanded and adapted by putting more time into wood collection and involvement of } \\
\text { younger children. Also, with developing formal schooling in the region, firewood collection has been adjusted to a shorter period prior to } \\
\text { school time. }\end{array}$ & Tian (2017) \\
\hline $\begin{array}{l}\text { Russia: After the collapse of the Soviet Union, Siberian Evenki people who were living in the Arctic forest tundra region of northwestern } \\
\text { Yakutia changed their basic subsistence from reindeer herding to a combination of herding and hunting due to environmental change, } \\
\text { political regime change, and economic development. }\end{array}$ & Takakura (2012) \\
\hline $\begin{array}{l}\text { Bolivia: As trends of diminishing water availability are recorded across the Andes, mountain peatlands (bofedales), which are the main } \\
\text { pastureland for camelid pastoralists, are becoming more degraded and drier. Consequently, Andean pastoralists have adopted collective } \\
\text { irrigation practices to rehabilitate these pastures which were used in the past. }\end{array}$ & $\begin{array}{l}\text { Yager et al. } \\
(2019)\end{array}$ \\
\hline $\begin{array}{l}\text { Benin: Fulbe pastoralists' perception and TEK regarding animal genetic breeds have adapted to new environmental and social-political } \\
\text { regulations. For instance, with encroachment of farmlands, which is resulting in the loss of grazing areas and watering points, cattle } \\
\text { herders' preferences for breeds are changing from high milk and meat production to breeds that are tolerant to hunger and long walks is } \\
\text { search for forage. Also, scarce grazing land had made pastoralists use specific breeds that are good at escaping from agents responsible for } \\
\text { illegal grazing. }\end{array}$ & $\begin{array}{l}\text { Tamou et al. } \\
\text { (2018) }\end{array}$ \\
\hline \multirow{2}{*}{\multicolumn{2}{|c|}{$\begin{array}{l}\text { Hybridization: Exposure to other knowledge systems and technologies leads to the development of hybrid knowledge and practices that } \\
\text { are based on them. This exposure may contribute to changes in management but also to a change of values pastoralists follow. } \\
\text { Hybridization - whether done voluntarily or involuntarily - is another strategy to make persistency of pastoral systems possible. }\end{array}$}} \\
\hline & \\
\hline $\begin{array}{l}\text { China: In the past, Tibetan herders' traditional knowledge influenced by Buddhist teaching viewed yaks as sentient beings that should not } \\
\text { be slaughtered; however, being subjected to market-driven logic, slaughtering is currently considered a necessary process. The } \\
\text { contemporary forces have resulted in the hybrid indigenous knowledge of Tibetan pastoralists in a way that most of them do not reject } \\
\text { one view for the other; rather, they employ both. }\end{array}$ & Gaerrang (2017) \\
\hline $\begin{array}{l}\text { Spain: Younger Spanish shepherds in the Cantabrian Mountains are exposed to external sources of training and information, including } \\
\text { the Internet, which has resulted in new understanding regarding scavengers and their role in other nature-based subsistence, such as } \\
\text { nature tourism. Therefore, the population of Griffon Vultures (Gyps fulvus) has increased due to this hybridization of knowledge. }\end{array}$ & $\begin{array}{l}\text { Morales-Reyes et } \\
\text { al. (2019) }\end{array}$ \\
\hline $\begin{array}{l}\text { Australia: Indigenous cattle herders' practices in Oriners Station (Indigenous-owned pastoral lease east of Kowanyama) have been } \\
\text { influenced by operational knowledge of national parks and contemporary management, which has led to hybridization of their }\end{array}$ & $\begin{array}{l}\text { Barber et al. } \\
\text { (2014) }\end{array}$ \\
\hline \multicolumn{2}{|l|}{$\begin{array}{l}\text { knowledge. Currently, pastoralists compromise with other involved stakeholders such as conservationists and scientists in implementing } \\
\text { their traditional-based practices such as horse riding. }\end{array}$} \\
\hline Uganda: As the result of being exposed to modern weather prediction techniques and information, pastoralists' knowledge in the & Nkuba et al. \\
\hline $\begin{array}{l}\text { Rwenzori region regarding predicting and forecasting weather features is currently a hybrid knowledge based both on scientific and } \\
\text { traditional knowledge. }\end{array}$ & (2019) \\
\hline \multicolumn{2}{|l|}{ Retention: Knowledge transmission is constantly occurring without any gap within or between generations. } \\
\hline $\begin{array}{l}\text { Kenya: Despite the gradual shift from a nomadic to sedentary lifestyle, pastoral knowledge regarding botanical features of plant species } \\
\text { was uniformly shared across age and gender, and source of livelihood. }\end{array}$ & Stave et al. (2007) \\
\hline $\begin{array}{l}\text { India: Children of the semi-nomadic Gujjar tribe (buffalo herders) in the high altitude of the Western Himalaya still accompany their } \\
\text { fathers and elder generation to the higher altitude and learn about useful plant species through observation. }\end{array}$ & $\begin{array}{l}\text { Rana et al. } \\
\text { (2019) }\end{array}$ \\
\hline $\begin{array}{l}\text { Ghana; Burkina Faso: Free forage plant listing ability of the elder generation was the same as younger generation. In some cases, it was } \\
\text { shown that younger generations carry greater knowledge pertaining to forage species than the elders, which showed the intrinsic flexible } \\
\text { nature of pastoral TEK acquisition and transmission. }\end{array}$ & $\begin{array}{l}\text { Naah and } \\
\text { Guuroh (2017) }\end{array}$ \\
\hline
\end{tabular}

opportunities for practicing TEK as an expression of culture are constrained by that new ecological trajectory. As a result, the loss itself, the cause of the loss, and the consequences of the loss are often interwoven; therefore, causes of TEK transition cannot be directly associated to simple factors. Nevertheless, we identified 13 drivers that are affecting pastoral TEK transitions, which were mentioned individually or in combination in the reviewed papers (Table 3). Social-cultural changes (13 citations), formal schooling (11 citations), abandonment of pastoral activities (11 citations), and transition to a market economy (10 citations) were the most often reported causes.

Social-cultural changes have been reported in several studies as a major driver of transition in TEK systems (Cristancho and Vining 2009, McCarter and Gavin 2014). Although pastoralism has a checkered history globally, social-cultural systems have been more exposed to diverse changes in the last century than in former times. Shifting from community-based management to governmental or state-based management has often come at the expense of local governance and autonomy (Reid et al. 2014). On this account, the share of top-down decision-making in rangeland management increased, which caused insurmountable barriers in the implementation of pastoral practices. Customary governance, which is underpinned by a dynamic network of vertical, horizontal, oblique, and retroactive transmission and sharing of pastoral TEK, has been drastically eroded as a result of rapid socio-political changes and land reform laws, globally (Greiner 2017). As a result, knowledge and experience input from elders and knowledgeable pastoralists devaluated (Tang and Gavin 2015). A Maasai cattle herder said "Before, we had a warming fire in the middle of the homestead. When the cows come in the evening all the shepherds have to come with the elders. The shepherds would narrate the story..." (Jandreau and Berkes 2016:9). Furthermore, in many places, pastoralism as a livelihood has lost its social status and value. A stockman from Spain said "It has been a fight against the current being a stockman, my stubbornness, and yet I see that it's in my son's blood" (FernándezGiménez and Estaque 2012:297). 
Table 3. Drivers of traditional ecological knowledge transition (numbers in parenthesis indicate the number of studies; the 3-letter abbreviations indicate the country in which the driver was reported).

\begin{tabular}{|c|c|}
\hline Driver & References \\
\hline $\begin{array}{l}\text { Social-cultural changes (13): China, India, } \\
\text { Spain, Kenya, Mongolia, Argentina, Benin, } \\
\text { Ethiopia, Nepal, Oman }\end{array}$ & $\begin{array}{l}\text { Tang and Gavin (2015); Salpeteur et al. (2015); Fernández-Giménez and Estaque (2012); Jandreau and } \\
\text { Berkes (2016); Fernandez-Gimenez (2000); Ladio and Lozada (2009); Oteros-Rozas et al. (2013); Gaoue } \\
\text { and Ticktin (2009); Belayneh et al. (2012); Seid et al. (2016); Dong (2017); Singh et al. (2015); Salman and } \\
\text { Kharusi (2014) }\end{array}$ \\
\hline $\begin{array}{l}\text { Formal schooling (11): China, Kenya, Nepal, } \\
\text { Pakistan, Spain, Egypt, Sudan, India, Ethiopia, } \\
\text { Tanzania, Uganda }\end{array}$ & $\begin{array}{l}\text { Tang and Gavin (2015); Bruyere et al. (2016); Jandreau and Berkes (2016); Spoon (2011); Aziz et al. } \\
\text { (2018); Oteros-Rozas et al. (2013); Hobbs et al. (2014); Dutt et al. (2015); Radeny et al. (2019); Hopping et } \\
\text { al. (2016); Kuriyan (2002) }\end{array}$ \\
\hline Abandonment of pastoral activities (11): Kenya, & Bruyere et al. (2016); Jandreau and Berkes (2016); Ladio and Lozada (2009); Oteros-Rozas et al. (2013); \\
\hline $\begin{array}{l}\text { Argentina, Spain, Hungary, Cyprus, Benin, } \\
\text { Algeria, Mauritania, Morocco, Italy, India }\end{array}$ & $\begin{array}{l}\text { Molnár (2014); Della et al. (2006); Gaoue and Ticktin (2009); Easdale and Aguiar (2018); Volpato et al. } \\
\text { (2015); Rippa et al. (2011); Singh et al. (2018) }\end{array}$ \\
\hline $\begin{array}{l}\text { Transition to a market economy (10): Mongolia, } \\
\text { Spain, China, Afghanistan, Tajikistan, Lesotho, } \\
\text { Pakistan, India, Kenya }\end{array}$ & $\begin{array}{l}\text { Fernandez-Gimenez (2000); Oteros-Rozas et al. (2013); Hernández-Morcillo et al. (2014); Liu (2013); } \\
\text { Kassam (2009); Morojele (2017); Post (2018); Raziq et al. (2010); Singh et al. (2015); Kuriyan (2002) }\end{array}$ \\
\hline $\begin{array}{l}\text { Policies and regulations (8): China, Spain, } \\
\text { Mongolia; Hungary, India, Nepal, Pakistan, } \\
\text { Finland }\end{array}$ & $\begin{array}{l}\text { Tang and Gavin (2015); Fernández-Giménez and Estaque (2012); Fernández-Giménez (2000); Oteros- } \\
\text { Rozas et al. (2013) (2015); Molnár (2014); Dong (2017); Raziq et al. (2010); Turunen et al. (2016) }\end{array}$ \\
\hline $\begin{array}{l}\text { Urbanization (8): China, Pakistan, Ethiopia, } \\
\text { Tanzania, Uganda, Cyprus, Egypt, Sudan, } \\
\text { Argentina, India, Nepal) }\end{array}$ & $\begin{array}{l}\text { Tang and Gavin (2015); Aziz et al. (2018); Radeny et al. (2019); Della et al. (2006); Andersen et al. (2014); } \\
\text { Easdale and Aguiar (2018); Dong (2017); Raziq et al. (2010) }\end{array}$ \\
\hline $\begin{array}{l}\text { Subsistence diversification (7): Kenya, Nepal, } \\
\text { China, Lesotho, India, Pakistan) }\end{array}$ & $\begin{array}{l}\text { Jandreau and Berkes (2016); Spoon (2011); Nyima and Hopping (2019); Liu (2013); Morojele (2017); } \\
\text { Singh et al. (2018); Raziq et al. (2010) }\end{array}$ \\
\hline $\begin{array}{l}\text { Modernization and technology (6): Kenya, } \\
\text { Pakistan, Spain, India, Finland }\end{array}$ & $\begin{array}{l}\text { Bruyere et al. (2016); Aziz et al. (2018); Oteros-Rozas et al. (2013); Dutt et al. (2015); Seid et al. (2016); } \\
\text { Turunen et al. (2016) }\end{array}$ \\
\hline $\begin{array}{l}\text { Environmental and climatic changes (6): Kenya, } \\
\text { Ethiopia, Tanzania, Uganda, Egypt, Pakistan, } \\
\text { Finland }\end{array}$ & $\begin{array}{l}\text { Speranza et al. (2010); Radeny et al. (2019); Yacoub (2018); Raziq et al. (2010); Feyssa et al. (2012); } \\
\text { Turunen et al. (2016) }\end{array}$ \\
\hline $\begin{array}{l}\text { Sedentarization (6): Egypt, Sudan, China, } \\
\text { Afghanistan, Tajikistan, Algeria, Mauritania, } \\
\text { Morocco, Pakistan }\end{array}$ & $\begin{array}{l}\text { Hobbs et al. (2014); Liu (2013); Kassam (2009); Volpato et al. (2015); Homann et al. (2008); Raziq et al. } \\
\text { (2010) }\end{array}$ \\
\hline $\begin{array}{l}\text { Agricultural expansion (5): Afghanistan, } \\
\text { Tajikistan, China, Italy, India }\end{array}$ & Kassam (2009); Liu (2013); Homann et al. (2008); Rippa et al. (2011); Singh et al. (2018) \\
\hline $\begin{array}{l}\text { Privatization (4): China, Kenya, Mongolia, } \\
\text { India, Nepal }\end{array}$ & Tang and Gavin (2015); Jandreau and Berkes (2016); Fernandez-Gimenez (2000); Dong (2017) \\
\hline Deagrarianization (1): Argentina & Ladio and Lozada (2009) \\
\hline
\end{tabular}

Formal schooling has also been mentioned as an important driver of TEK erosion in groups other than pastoralists (Harvey 2013, Reyes-García et al. 2013). Consolidation and development of formal schooling services detached children's connections with pastoral activities and forced the children to live away from pastoral lands. It even forced some pastoral families to abandon their lifestyle and live where school services were available (Tang and Gavin 2015). Thus, the dynamic nature of nomadism and a transhumance lifestyle increases the challenge of formal education for pastoralists' children compared to children in permanently settled agriculturalist communities (Bruyere et al. 2016). Also, the lack of pastoral TEK in the formal school curricula is another negative point that increases the distance between the new generation and the previous cultural lifestyle (see Reyes-García et al. [2010] for a thorough discussion of this topic). Therefore, pastoral TEK among children who become distanced from a constant presence in nature gradually vanishes (Bruyere et al. 2016). "Old people have lots of experiences, and young people have good educations" (Hopping et al. 2016:32). [Educated children that live in the town] "cannot live in the desert anymore" (Hobbs et al. 2014:2939). Countries where formal schooling is negatively affecting pastoral TEK can consider educational systems and curricula through which this challenge can be partially addressed. For example, the Mongolian education system has made traditional pastoral history and culture the basis of many textbooks in a genuine attempt to teach new generations about the important cultural, social, economic, and environmental values of pastoralism. As an example, pupils in Grades 2-3 read the famous poem in their Social Science class: "Dung smoke pouring forth, I was born in a herder's home, on the wilderness steppe, I think of my native land" (Gardelle and Zhao 2019:12). Mobile schools also can help reach formal educational goals while keeping pastoral TEK and practices alive for the new generation of pastoralists. Tribal schools initially established in Iran by Mohammad Bahman Beigi and reinvigorated in the post-revolutionary era could serve as a good example (Annamoradnejad and Lotfi 2010). Nevertheless, it must be emphasized that achieving a proper educational model that feeds the sustainability of pastoral social-ecological systems while also satisfying the changing modern world requires participatory involvement of pastoralists and local decision-makers (Dyer and Echessa 2019).

\section{CONCLUSION}

Constant long-term presence and monitoring by pastoralists of their social-ecological systems have enabled them to develop rich bodies of knowledge and practices about their local ecologies. Understanding this knowledge is pivotal for sustainable 
management and nature conservation. Furthermore, several global reports such as IPBES (2019), Karki et al. (2017), and an extensive body of scholarly literature (Fernández-Giménez 2015, Molnár et al. 2020, Fernández-Llamazares et al. 2021) have already shown that traditional, Indigenous, and local communities, including many pastoralist societies, are not only interested in the benefits that they gain from nature, but they are also concerned about other components of social-ecological systems such as flora, fauna, soil, water, etc. and the conservation and sustainable use of them. Previous studies have raised awareness of potential important gaps in pastoral TEK. We report that only $3 \%$ of TEK studies globally addressed pastoral TEK, thus identifying important research gaps. Our study also identifies where (geographically, knowledge domains, types of change) those gaps are, thus contributing to preparations for the largely endorsed proposal of the International Year of Rangelands and Pastoralists for 2026 (https://iyrp.info/). One of the primary goals of the planned International Year of Rangelands and Pastoralists is pursuing and addressing the challenges of pastoralists' traditional knowledge. Documenting the transition status of pastoralists' knowledge can help the United Nations as well as different governmental and nongovernmental organizations understand the current condition of pastoral TEK systems. Furthermore, a global assessment can provide fundamental information upon which decision-making and planning can be undertaken to eliminate the obstacles that limit pastoralists in executing their TEK-based practices. Despite the fact that pastoralists carry knowledge in several domains, the limited research on pastoral TEK has focused more often on Herd/Livestock, Forage/Medicine, and Landscape/Wildlife; Climate and Socio-cultural domains are less studied. International planning and management for rangeland and pastoralism is not possible when our knowledge pertaining to pastoral TEK is not detailed enough.

Notwithstanding the number of studies on pastoral TEK, our review showed that knowledge erosion may be the dominant type of knowledge transition occurring among pastoralists worldwide. However, knowledge adaptation and hybridization were shown to be critical in the implementation of solutions to new socialecological challenges in many areas of the world, despite the fact that they continue to be under-researched. Changes in pastoral TEK are caused by many interwoven drivers. Although documentation of pastoral TEK in scientific papers and reports is a helpful start, safeguarding pastoral TEK requires a fundamental shift across sectors in how such knowledge systems are recognized, affirmed, and sustained. We argue that research on pastoral TEK could help advance policy on pastoralism (e.g., by highlighting the ways in which pastoralism contributes to planetary sustainability, and the contexts that facilitate or undermine such contributions). More specifically, research on TEK dynamics could bring into focus the different transition types and help avoid the common mischaracterization of all knowledge changes as symptoms of vulnerability and loss. By focusing on knowledge hybridization and adaptation, future research efforts could pay justice to the immense and powerful cultural continuity that is a hallmark of pastoral societies worldwide, and affirm their ongoing struggles to foster socialecological resilience over the long run.
Responses to this article can be read online at: https://www.ecologyandsociety.org/issues/responses. php/12918

\section{Author Contributions:}

All authors made substantial contributions to the final product. . All authors read and approved the final manuscript.

\section{Acknowledgments:}

We would like to give our appreciation to all the pastoral communities whose knowledge and participation provided the basis for this study. We gratefully acknowledge all the researchers whose studies push the boundaries of knowledge on pastoral communities. We would like to extend our gratitude to the anonymous reviewers for their constructive feedback on an earlier version of this paper. We wish to thank IUBS for support of the Global Integrative Pastoralism Program. This research was partly supported by project GINOP-2.3.2-15-2016-00019, the PhD candidates' scholarship program of Ministry of Science, Research and Technology from Iran and the project "Effects of extensive grazing on vegetation in non-conventional pasture-lands (marshes and forests)" [grant number NKFIH K 119478]. This research had the support of IUBS through the GIPP project.

\section{Data Availability:}

Datalcode available upon request because of privacylethical restrictions.

\section{LITERATURE CITED}

Adriansen, H. K. 2008. Understanding pastoral mobility: the case of Senegalese Fulani. Geographical Journal 174(3):207-222. https://doi.org/10.1111/j.1475-4959.2008.00278.x

Ahearn, A., M. Oelz, and R. Kumar Dhir. 2019. Indigenous peoples and climate change - emerging research on traditional knowledge and livelihoods. International Labour Organization.

Andersen, G. L., K. Krzywinski, M. Talib, A. E. Saadallah, J. J. Hobbs, and R. H. Pierce. 2014. Traditional nomadic tending of trees in the Red Sea Hills. Journal of Arid Environments 106:36-44. https://doi.org/10.1016/j.jaridenv.2014.02.009

Annamoradnejad, R., and S. Lotfi. 2010. Demographic changes of nomadic communities in Iran (1956-2008). Asian Population Studies 6(3):335-345. https://doi.org/10.1080/17441730.2010.512764

Aswani, S., A. Lemahieu, and W. H. Sauer. 2018. Global trends of local ecological knowledge and future implications. PloS One 13(4):e0195440. https://doi.org/10.1371/journal.pone.0195440

Aziz, M. A., A. H. Khan, M. Adnan, and H. Ullah. 2018. Traditional uses of medicinal plants used by Indigenous communities for veterinary practices at Bajaur Agency, Pakistan. Journal of Ethnobiology and Ethnomedicine 14:11. https://doi. org/10.1186/s13002-018-0212-0 
Barber, M., S. Jackson, J. Shellberg, and V. Sinnamon. 2014. Working knowledge: characterising collective Indigenous, scientific, and local knowledge about the ecology, hydrology and geomorphology of Oriners Station, Cape York Peninsula, Australia. Rangeland Journal 36(1):53-66. https://doi.org/10.1071/ RJ13083

Belayneh, A., Z. Asfaw, S. Demissew, and N. F. Bussa. 2012. Medicinal plants potential and use by pastoral and agro-pastoral communities in Erer Valley of Babile Wereda, Eastern Ethiopia. Journal of Ethnobiology and Ethnomedicine 8:42. https://doi. org/10.1186/1746-4269-8-42

Belayneh, A., and Z. K. Tessema. 2017. Mechanisms of bush encroachment and its inter-connection with rangeland degradation in semi-arid African ecosystems: a review. Journal of Arid Land 9(2):299-312. https://doi.org/10.1007/s40333-016-0023$\underline{\mathrm{X}}$

Berkes, F., J. Colding, and C. Folke. 2000. Rediscovery of traditional knowledge as adaptive management. Ecological Applications 10:1251-1262. https://doi.org/10.1890/1051-0761 (2000)010[1251:ROTEKA]2.0.CO;2

Brondízio, E. S., Y. Aumeeruddy-Thomas, P. Bates, J. Carino, Á. Fernndez-Llamazares, M. F. Ferrari, K. Galvin, V. Reyes-García, P. McElwee, Z. Molnár, A. Samakov, and U. B. Shrestha. 2021. Locally based, regionally manifested, and globally relevant: indigenous and local knowledge, values, and practices for nature. Annual Review of Environment and Resources 46:481-509. https://doi.org/10.1146/annurev-environ-012220-012127

Brook, R. K., and S. M. McLachlan. 2008. Trends and prospects for local knowledge in ecological and conservation research and monitoring. Biodiversity and Conservation 17(14):3501-3512. https://doi.org/10.1007/s10531-008-9445-X

Bruyere, B. L., J. Trimarco, and S. Lemungesi. 2016. A comparison of traditional plant knowledge between students and herders in northern Kenya. Journal of Ethnobiology and Ethnomedicine 12:48. https://doi.org/10.1186/s13002-016-0121-Z

Bussmann, R. W., N. Y. Paniagua-Zambrana, N. Wood, S. O. Njapit, J. N. O. Njapit, G. S. E. Osoi, and S. P. Kasoe. 2018. Knowledge loss and change between 2002 and 2017-a revisit of plant use of the Maasai of Sekenani Valley, Maasai Mara, Kenya. Economic Botany 72(2):207-216. https://doi.org/10.1007/ $\underline{\text { s12231-018-9411-9 }}$

Cavalli-Sforza, L. L., M. W. Feldman, K. H. Chen, and S. M. Dornbusch. 1982. Theory and observation in cultural transmission. Science 218(4567):19-27. https://doi.org/10.1126/ science. 7123211

Cristancho, S., and J. Vining. 2009. Perceived intergenerational differences in the transmission of traditional ecological knowledge (TEK) in two Indigenous groups from Colombia and Guatemala. Culture \& Psychology 15(2):229-254. https://doi. org/10.1177/1354067X09102892

Della, A., D. Paraskeva-Hadjichambi, and A. C. Hadjichambis. 2006. An ethnobotanical survey of wild edible plants of Paphos and Larnaca countryside of Cyprus. Journal of Ethnobiology and Ethnomedicine 2:34. https://doi.org/10.1186/1746-4269-2-34
Dong, S. 2017. Himalayan grasslands: Indigenous knowledge and institutions for social innovation. Pages 99-126 in S. Dong, J. Bandyopadhyay, and S. Chaturvedi, editors. Environmental sustainability from the Himalayas to the oceans. Springer. https:// doi.org/10.1007/978-3-319-44037-8 5

Dong, S., L. Wen, S. Liu, X. Zhang, J. P. Lassoie, S. Yi, X. Li, J. Li, and Y. Li. 2011. Vulnerability of worldwide pastoralism to global changes and interdisciplinary strategies for sustainable pastoralism. Ecology and Society 16(2):10. https://doi. org/10.5751/ES-04093-160210

Duenn, P., M. Salpeteur, and V. Reyes-García. 2017. Rabari shepherds and the mad tree: the dynamics of local ecological knowledge in the context of Prosopis juliflora invasion in Gujarat, India. Journal of Ethnobiology 37(3):561-580. https://doi. org/10.2993/0278-0771-37.3.561

Dutt, H. C., N. Bhagat, and S. Pandita. 2015. Oral traditional knowledge on medicinal plants in jeopardy among Gaddi shepherds in hills of northwestern Himalaya, J\&K, India. Journal of Ethnopharmacology 168:337-348. https://doi.org/10.1016/j. jep.2015.03.076

Dyer, C., and E. Echessa. 2019. Sustaining learner participation and progression through networked schooling: a systemic approach for Mobile Out of School Children. International Journal of Educational Development 64:8-16. https://doi. org/10.1016/j.ijedudev.2018.11.002

Easdale, M. H., and M. R. Aguiar. 2018. From traditional knowledge to novel adaptations of transhumant pastoralists the in face of new challenges in North Patagonia. Journal of Rural Studies 63:65-73. https://doi.org/10.1016/j.jrurstud.2018.09.001

Ellis, E. C., N. Gauthier, K. K. Goldewijk, R. Bliege Bird, N. Boivin, S. Díaz, D. Fuller, et al. 2021. People have shaped most of terrestrial nature for at least 12,000 years. Proceedings of the National Academy of Sciences of the United States of America 118:e2023483118. https://doi.org/10.1073/pnas.2023483118

Farooquee, N. A., and A. Nautiyal. 1999. Traditional knowledge and practices of Bhotiya pastoralists of Kumaon Himalaya: the need for value addition. International Journal of Sustainable Development \& World Ecology 6(1):60-67. https://doi. org/10.1080/13504509.1999.9728472

Fernández-Giménez, M. E. 2000. The role of Mongolian nomadic pastoralists' ecological knowledge in rangeland management. Ecological Applications 10(5):1318-1326. https:// doi.org/10.1890/1051-0761(2000)010[1318:TROMNP]2.0.CO:2

Fernández-Giménez, M. E. 2015. "A shepherd has to invent": poetic analysis of social-ecological change in the cultural landscape of the central Spanish Pyrenees. Ecology and Society 20(4):29. https://doi.org/10.5751/ES-08054-200429

Fernández-Giménez, M. E., and F. F. Estaque. 2012. Pyrenean pastoralists' ecological knowledge: documentation and application to natural resource management and adaptation. Human Ecology 40(2):287-300. https://doi.org/10.1007/s10745-012-9463$\underline{x}$

Fernández-Llamazares, Á., I. Díaz-Reviriego, A. C. Luz, M. Cabeza, A. Pyhälä, and V. Reyes-García. 2015. Rapid ecosystem 
change challenges the adaptive capacity of Local Environmental Knowledge. Global Environmental Change 31:272-284. https:// doi.org/10.1016/j.gloenvcha.2015.02.001

Fernández-Llamazares, Á., D. Lepofsky, K. Lertzman, C. G. Armstrong, E. S. Brondizio, M. C. Gavin, P. O. B. Lyver, G. P. Nicholas, N. J. Reo, V. Reyes-García, N. J. Turner, et al. 2021. Scientists' warning to humanity on threats to Indigenous and local knowledge systems. Journal of Ethnobiology 41(2):144-169. https://doi.org/10.2993/0278-0771-41.2.144

Feyssa, D. H., J. T. Njoka, Z. Asfaw, and M. M. Nyangito. 2012. Uses and management of Ximenia americana, Olacaceae in semiarid East Shewa, Ethiopia. Pakistan Journal of Botany 44:1177-84.

Ford, J. D., L. Cameron, J. Rubis, M. Maillet, D. Nakashima, A. C. Willox, and T. Pearce, 2016. Including indigenous knowledge and experience in IPCC assessment reports. Nature Climate Change 6:34953. https://doi.org/10.1038/nclimate2954

Ford, J. D., N. King, E. K. Galappaththi, T. Pearce, G. McDowell, and S. L. Harper. 2020. The resilience of Indigenous peoples to environmental change. One Earth 2:532543. https://doi. org/10.1016/j.oneear.2020.05.014

Fynn, R. W., D. J. Augustine, M. J. Peel, and M. de GarineWichatitsky. 2016. Strategic management of livestock to improve biodiversity conservation in African savannahs: a conceptual basis for wildlife-livestock coexistence. Journal of Applied Ecology 53(2):388-397. https://doi.org/10.1111/1365-2664.12591

Gaerrang, K. 2017. Tibetan Buddhism, wetland transformation, and environmentalism in Tibetan pastoral areas of western China. Conservation and Society 15(1):14-23. https://www.jstor. org/stable/26393267

Gallois, S., R. Duda, B. Hewlett, and V. Reyes-García. 2015. Children's daily activities and knowledge acquisition: a case study among the Baka from southeastern Cameroon. Journal of Ethnobiology and Ethnomedicine 11:86. https://doi.org/10.1186/ $\underline{\text { s13002-015-0072-9 }}$

Galvin, K. A. 2009. Transitions: pastoralists living with change. Annual Review of Anthropology 38:185-198. https://doi. org/10.1146/annurev-anthro-091908-164442

Gaoue, O. G., and T. Ticktin. 2009. Fulani knowledge of the ecological impacts of Khaya senegalensis (Meliaceae) foliage harvest in Benin and its implications for sustainable harvest. Economic Botany 63(3):256-270. https://doi.org/10.1007/ $\underline{\text { s12231-009-9091-6 }}$

Gardelle, L., and Z. Zhao. 2019. Being a herder in contemporary Mongolia: nomadic identity and nationhood building at school. Asian Ethnicity 20(3):364-385. https://doi.org/10.1080/14631369.2019.1586521

Greiner, C. 2017. Pastoralism and land-tenure change in Kenya: the failure of customary institutions. Development and Change 48(1):78-97. https://doi.org/10.1111/dech.12284

Hanazaki, N., D. F. Herbst, M. S. Marques, and I. Vandebroek. 2013. Evidence of the shifting baseline syndrome in ethnobotanical research. Journal of Ethnobiology and Ethnomedicine 9(1):75. https://doi.org/10.1186/1746-4269-9-75
Harvey, J. 2013. Investigating the relationships between formal schooling and ethnoveterinary knowledge in Eluwai village, Tanzania. Dissertation. Canterbury Christ Church University, UK.

Hedges, K., J. O. Kipila, and R. Carriedo-Ostos. 2020. "There are no trees here": understanding perceived intergenerational erosion of traditional medicinal knowledge among Kenya Purko Maasai in Narok District. Journal of Ethnobiology 40:535-551. https:// doi.org/10.2993/0278-0771-40.4.535

Hernández-Morcillo, M., J. Hoberg, E. Oteros-Rozas, T. Plieninger, E. Gómez-Baggethun, and V. Reyes-García. 2014. Traditional ecological knowledge in Europe: status quo and insights for the environmental policy agenda. Environment: Science and Policy for Sustainable Development 56(1):3-17. https://doi.org/10.1080/00139157.2014.861673

Herrero, M., J. Addison, C. Bedelian, E. Carabine, P. Havlík, B. Henderson, J. Van De Steeg, and P. K. Thornton. 2016. Climate change and pastoralism: impacts, consequences and adaptation. Revue Scientifique et Technique 35:417-33.

Hobbs, J. J., K. Krzywinski, G. L. Andersen, M. Talib, R. H. Pierce, and A. E. Saadallah. 2014. Acacia trees on the cultural landscapes of the Red Sea Hills. Biodiversity and Conservation 23(12):2923-2943. https://doi.org/10.1007/s10531-014-0755-x

Hoffmann, I., T. From, and D. Boerma. 2014. Ecosystem services provided by livestock species and breeds, with special consideration to the contributions of small-scale livestock keepers and pastoralists. Food and Agriculture Organization, Rome.

Holling, C. S., and L. H. Gunderson. 2002. Panarchy: understanding transformations in human and natural systems. Island Press, Washington, D.C., USA.

Homann, S., B. Rischkowsky, and J. Steinbach. 2008. The effect of development interventions on the use of Indigenous range management strategies in the Borana Lowlands in Ethiopia. Land Degradation \& Development 19(4):368-387. https://doi. org/10.1002/ldr.845

Hopping, K. A., C. Yangzong, and J. A. Klein. 2016. Local knowledge production, transmission, and the importance of village leaders in a network of Tibetan pastoralists coping with environmental change. Ecology and Society 21(1):25. https://doi. org/10.5751/ES-08009-210125

Intergovernmental Science-Policy Platform on Biodiversity and Ecosystem Services (IPBES). 2019. Summary for policymakers of the global assessment report on biodiversity and ecosystem services of the Intergovernmental Science-Policy Platform on Biodiversity and Ecosystem Services. S. Díaz, J. Settele, E. S. Brondízio E.S., H. T. Ngo, M. Guèze, J. Agard, A. Arneth, P. Balvanera, K. A. Brauman, S. H. M. Butchart, K. M. A. Chan, L. A. Garibaldi, K. Ichii, J. Liu, S. M. Subramanian, G. F. Midgley, P. Miloslavich, Z. Molnár, D. Obura, A. Pfaff, S. Polasky, A. Purvis, J. Razzaque, B. Reyers, R. Roy Chowdhury, Y. J. Shin, I. J. Visseren-Hamakers, K. J. Willis, and C. N. Zayas, editors. IPBES Secretariat, Bonn, Germany.

Intergovernmental Science-Policy Platform on Biodiversity and Ecosystem Services (IPBES). 2021. Glossary. [online] URL: https://ipbes.net/glossary 
Jandreau, C., and F. Berkes. 2016. Continuity and change within the social-ecological and political landscape of the Maasai Mara, Kenya. Pastoralism 6(1):1-15. https://doi.org/10.1186/s13570-016-0048y

Johnsen, K. I., M. Niamir-Fuller, A. Bensada, and A. WatersBayer. 2019. A case of benign neglect: knowledge gaps about sustainability in pastoralism and rangelands. United Nations Environment Programme and GRID-Arendal, Nairobi and Arendal.

Karki, M., R. Hill, D. Xue, W. Alangui, K. Ichikawa, and P. Bridgewater, editors. 2017. Knowing our lands and resources: Indigenous and local knowledge and practices related to biodiversity and ecosystem services in Asia. Knowledges of Nature 10. United Nations Educational, Scientific and Cultural Organization, Paris, France.

Kassam, K.-A. 2009. Viewing change through the prism of Indigenous human ecology: findings from the Afghan and Tajik Pamirs. Human Ecology 37:677. https://doi.org/10.1007/ $\underline{\text { s10745-009-9284-8 }}$

Kelly, D. 2020. International year of rangelands and pastoralists. Proceedings of the Royal Society of Queensland 127:91.

Köhler-Rollefson, I. 2020. Accounting for pastoralists: Why is it important and how to do it? League for Pastoral Peoples and Endogenous Livestock Development, Ober-Ramstadt, Germany.

Kuriyan, R. 2002. Linking local perceptions of elephants and conservation: Samburu pastoralists in northern Kenya. Society \& Natural Resources 15(10):949-957. https://doi. org/10.1080/08941920290107675

Ladio, A. H., and M. Lozada. 2009. Human ecology, ethnobotany and traditional practices in rural populations inhabiting the Monte region: resilience and ecological knowledge. Journal of Arid Environments 73(2):222-227. https://doi.org/10.1016/j. jaridenv.2008.02.006

League for Pastoral Peoples (LPP). 2021. Pastoralist map. League for Pastoral Peoples and Endogenous Livestock Development, Ober-Ramstadt, Germany.

Liu, G. 2013. Wild plant folk nomenclature of the Mongol herdsmen in the Arhorchin national nature reserve, Inner Mongolia, PR China. Journal of Ethnobiology and Ethnomedicine 9:30. https://doi.org/10.1186/1746-4269-9-30

Lyver, P. O’B., P. Timoti, T. Davis, and J. M. Tylianakis. 2019. Biocultural hysteresis inhibits adaptation to environmental change. Trends in Ecology and Evolution 34(9):771-780. https:// doi.org/10.1016/j.tree.2019.04.002

Manzano, P., D. Burgas, L. Cadahía, J. T. Eronen, Á. FernándezLlamazares, S. Bencherif, Ø. Holand, O. Seitsonen, B. Byambaa, M. Fortelius, and M. E. Fernández-Giménez. 2021. Toward a holistic understanding of pastoralism. One Earth 4(5):651-665. https://doi.org/10.1016/j.oneear.2021.04.012

Maxted, N., L. Guarino, L. Myer, and E. A. Chiwona. 2002. Towards a methodology for on-farm conservation of plant genetic resources. Genetic Resources and Crop Evolution 49(1):31-46. https://doi.org/10.1023/A:1013896401710
McCarter, J., and M. C. Gavin. 2014. Local perceptions of changes in traditional ecological knowledge: a case study from Malekula Island, Vanuatu. Ambio 43(3):288-296. https://doi. org/10.1007/s13280-013-0431-5

McCarter, J., M. C. Gavin, S. Baereleo, and M. Love. 2014. The challenges of maintaining indigenous ecological knowledge. Ecology and Society 19(3):39. https://doi.org/10.5751/ES-06741-190339

McGahey, D., J. Davies, N. Hagelberg, and R. Ouedraogo. 2014. Pastoralism and the green economy - a natural nexus? International Union for Conservation of Nature and United Nations Environment Programme, Nairobi, Kenya.

Molnár, Z. 2014. Perception and management of spatio-temporal pasture heterogeneity by Hungarian herders. Rangeland Ecology \& Management 67(2):107-118. https://doi.org/10.2111/REMD-13-00082.1

Molnár, Z. 2017. "I see the grass through the mouths of my animals" - folk indicators of pasture plants used by traditional steppe herders. Journal of Ethnobiology 37(3):522-541. https:// doi.org/10.2993/0278-0771-37.3.522

Molnár, Z., A. Kelemen, R. Kun, J. Máté, L. Sáfián, F. Provenza, S. Díaz, H. Barani, M. Biró, A. Máté, and Cs. Vadász. 2020. Knowledge co-production with traditional herders on cattle grazing behaviour for better management of species-rich grasslands. Journal of Applied Ecology 57:1677-1687. https://doi. org/10.1111/1365-2664.13664

Morales-Reyes, Z., B. Martín-López, M. Moleón, P. MateoTomás, P. P. Olea, E. Arrondo, J. A. Donázar, and J. A. SánchezZapata. 2019. Shepherds' local knowledge and scientific data on the scavenging ecosystem service: insights for conservation. Ambio 48(1):48-60. https://doi.org/10.1007/s13280-018-1055-6

Morojele, P. 2017. Indigenous knowledge/s of survival: implications for lifelong learning among the Basotho herding fraternity. Educational Research for Social Change 6(1):38-55. https://doi.org/10.17159/2221-4070/2017/v6ila4

Naah, J. B. S., and R. T. Guuroh. 2017. Factors influencing local ecological knowledge of forage resources: ethnobotanical evidence from West Africa's savannas. Journal of Environmental Management 188:297-307. https://doi.org/10.1016/j.jenvman.2016.11.064

Nedelcheva, A., A. Pieroni, and Y. Dogan. 2017. Folk food and medicinal botanical knowledge among the last remaining Yoruks of the Balkans. Acta Societatis Botanicorum Poloniae 86(2). https://doi.org/10.5586/asbp. 3522

Nkuba, M., R. Chanda, G. Mmopelwa, E. Kato, M. N. Mangheni, and D. Lesolle. 2019. The effect of climate information in pastoralists' adaptation to climate change: a case study of Rwenzori region, Western Uganda. International Journal of Climate Change Strategies and Management 11(4):442-464. https://doi.org/10.1108/IJCCSM-10-2018-0073

Nyima, Y., and K. A. Hopping. 2019. Tibetan lake expansion from a pastoral perspective: local observations and coping strategies for a changing environment. Society \& Natural Resources 32(9):965-982. https://doi.org/10.1080/08941920.2019.1590667 
Olsson, P., and C. Folke. 2001. Local ecological knowledge and institutional dynamics for ecosystem management: a study of Lake Racken watershed, Sweden. Ecosystems 4(2):85-104. https://doi.org/10.1007/s100210000061

Oteros-Rozas, E., R. Ontillera-Sánchez, P. Sanosa, E. GómezBaggethun, V. Reyes-García, and J. A. González. 2013. Traditional ecological knowledge among transhumant pastoralists in Mediterranean Spain. Ecology and Society 18(3):33. https:// doi.org/10.5751/ES-05597-180333

Post, J.C. 2018. Climate change and cultural heritage in western Mongolia. Leonardo 51(03):285-286. https://doi.org/10.1162/ $\underline{\text { leon a } 01533}$

Radeny, M., A. Desalegn, D. Mubiru, F. Kyazze, H. Mahoo, J. Recha, P. Kimeli, and D. Solomon. 2019. Indigenous knowledge for seasonal weather and climate forecasting across East Africa. Climatic Change 156(4):509-526. https://doi.org/10.1007/ s10584-019-02476-9

Rana, D., A. Bhatt, and B. Lal. 2019. Ethnobotanical knowledge among the semi-pastoral Gujjar tribe in the high altitude (Adhwari's) of Churah subdivision, district Chamba, Western Himalaya. Journal of Ethnobiology and Ethnomedicine 15:10. https://doi.org/10.1186/s13002-019-0286-3

Raziq, A., K. de Verdier, and M. Younas. 2010. Ethnoveterinary treatments by dromedary camel herders in the Suleiman Mountainous Region in Pakistan: an observation and questionnaire study. Journal of Ethnobiology and Ethnomedicine 6:16. https://doi.org/10.1186/1746-4269-6-16

Reid, R. S., M. E. Fernández-Giménez, and K. A. Galvin. 2014. Dynamics and resilience of rangelands and pastoral peoples around the globe. Annual Review of Environment and Resources 39:217-242. https://doi.org/10.1146/annurev-environ-020713-163329

Reyes-García, V., Á. Fernández-Llamazares, M. Guèze, A. Garcés, M. Mallo, M. Vila-Gómez, and M. Vilaseca. 2015. Local indicators of climate change: the potential contribution of local knowledge to climate research. WIRES: Climate Change 7 (1):109-124.

Reyes-García, V., M. Guèze, A. C. Luz, J. Paneque-Gálvez, M. J. Macía, M. Orta-Martínez, J. Pino, and X. Rubio-Campillo. 2013. Evidence of traditional knowledge loss among a contemporary Indigenous society. Evolution and Human Behavior 34 (4):249-257. https://doi.org/10.1016/j.evolhumbehav.2013.03.002

Reyes-García, V., E. Kightley, I. Ruiz-Mallén, N. Fuentes-Peláez, K. Demps, T. Huanca, and M. R. Martínez-Rodríguez. 2010. Schooling and local environmental knowledge: Do they complement or substitute each other? International Journal of Educational Development 30(3):305-313. https://doi.org/10.1016/ j.ijedudev.2009.11.007

Rippa, D., V. Maselli, O. Soppelsa, and D. Fulgione. 2011. The impact of agro-pastoral abandonment on the Rock Partridge Alectoris graeca in the Apennines. Ibis 153(4):721-734. https:// doi.org/10.1111/j.1474-919X.2011.01156.X

Salman, A., and N. S. Kharusi. 2014. Female camel nomenclature among Arabia's Bedouins. Names 62(2):86-99. https://doi. org/10.1179/0027773814Z.00000000076
Salpeteur, M., H. Patel, A. L. Balbo, X. Rubio-Campillo, M. Madella, P. Ajithprasad, and V. Reyes-García. 2015. When knowledge follows blood: kin groups and the distribution of traditional ecological knowledge in a community of seminomadic pastoralists, Gujarat (India). Current Anthropology 56 (3):471-483. https://doi.org/10.1086/681006

Salpeteur, M., H. H. Patel, J. L. Molina, A. L. Balbo, X. RubioCampillo, V. Reyes-García, and M. Madella. 2016. Comigrants and friends: informal networks and the transmission of traditional ecological knowledge among seminomadic pastoralists of Gujarat, India. Ecology and Society 21(2):20. https://doi. org/10.5751/ES-08332-210220

Seid, M. A., L. W. Yoseph, U. W. Befekadu, A. Muhammed, and T. Z. Fikre. 2016. Communication for the development of pastoralism. Revue Scientifique et Technique (International Office of Epizootics) 35(2):639-648.

Shen, H., S. Dong, S. Li, J. Xiao, Y. Han, M. Yang, J. Zhang, X. Gao, Y. Xu, Y. Li, Y. Zhi, et al. 2019. Grazing enhances plant photosynthetic capacity by altering soil nitrogen in alpine grasslands on the Qinghai-Tibetan plateau. Agriculture, Ecosystems and Environment 280:161-168. https://doi. org/10.1016/j.agee.2019.04.029

Singh, R. K., A. Singh, S. T. Garnett, K. K. Zander, and D. Tsering. 2015. Paisang (Quercus griffithii): a keystone tree species in sustainable agroecosystem management and livelihoods in Arunachal Pradesh, India. Environmental Management 55 (1):187-204. https://doi.org/10.1007/s00267-014-0383-y

Singh, R. K., A. K. Sureja, S. Maiti, and D. Tsering, 2018. Grazing and rangeland management: trans-human adaptations by Brokpa community in fragile ecosystems of Arunachal Pradesh. Indian Journal of Traditional Knowledge 17(3).

Speranza, C. I., B. Kiteme, P. Ambenje, U. Wiesmann, and S. Makali. 2010. Indigenous knowledge related to climate variability and change: insights from droughts in semi-arid areas of former Makueni District, Kenya. Climatic Change 100(2):295-315. https://doi.org/10.1007/s10584-009-9713-0

Spoon, J. 2011. The heterogeneity of Khumbu Sherpa ecological knowledge and understanding in Sagarmatha (Mount Everest) National Park and Buffer Zone, Nepal. Human Ecology 39 (5):657. https://doi.org/10.1007/s10745-011-9424-9

Srithi, K., H. Balslev, P. Wangpakapattanawong, P. Srisanga, and C. Trisonthi. 2009. Medicinal plant knowledge and its erosion among the Mien (Yao) in northern Thailand. Journal of Ethnopharmacology 123(2):335-342. https://doi.org/10.1016/j. jep.2009.02.035

Stave, J., G. Oba, I. Nordal, and N. C. Stenseth, 2007. Traditional ecological knowledge of a riverine forest in Turkana, Kenya: implications for research and management. Biodiversity and Conservation 16(5):1471-1489. https://doi.org/10.1007/s10531-006-9016y

Stolton, S., N. Dudley, and L. Zogib. 2019. Mobile pastoralism and world heritage. DiversEarth, Switzerland.

Takakura, H. 2012. The shift from herding to hunting among the Siberian Evenki: Indigenous knowledge and subsistence change in Northwestern Yakutia. Asian Ethnology 71(1):31-47. 
Tamou, C., I. J. de Boer, R. Ripoll-Bosch, and S. J. Oosting. 2018. Understanding roles and functions of cattle breeds for pastoralists in Benin. Livestock Science 210:129-136. https://doi. org/10.1016/j.livsci.2018.02.013

Tang, R., and M. C. Gavin. 2015. Degradation and re-emergence of the commons: the impacts of government policies on traditional resource management institutions in China. Environmental Science \& Policy 52:89-98. https://doi. org/10.1016/j.envsci.2015.04.023

Thomas, D. S. G., and C. Twyman. 2004. Good or bad rangeland? Hybrid knowledge, science, and local understandings of vegetation dynamics in the Kalahari. Land Degradation \& Development 15(3):215-231. https://doi.org/10.1002/1dr.610

Tian, X. 2017. Ethnobotanical knowledge acquisition during daily chores: the firewood collection of pastoral Maasai girls in Southern Kenya. Journal of Ethnobiology and Ethnomedicine 13:2. https://doi.org/10.1186/s13002-016-0131-x

Turner, N. J., M. B. Ignace, and R. Ignace. 2000. Traditional ecological knowledge and wisdom of aboriginal peoples in British Columbia. Ecological Applications 10(5):1275-1287. https://doi. org/10.1890/1051-0761(2000)010[1275:TEKAWO]2.0.CO:2

Turunen, M. T., S. Rasmus, M. Bavay, K. Ruosteenoja, and J. Heiskanen. 2016. Coping with difficult weather and snow conditions: reindeer herders' views on climate change impacts and coping strategies. Climate Risk Management 11:15-36. https:// doi.org/10.1016/j.crm.2016.01.002

Volpato, G., S. M. L. Saleh, and A. Di Nardo. 2015. Ethnoveterinary of Sahrawi pastoralists of Western Sahara: camel diseases and remedies. Journal of Ethnobiology and Ethnomedicine 11:54.https://doi.org/10.1186/s13002-015-0040-4

Wu, N., M. Ismail, S. Joshi, S. L. Yi, R. M. Shrestha, and A.W. Jasra. 2014. Livelihood diversification as an adaptation approach to change in the pastoral Hindu-Kush Himalayan region. Journal of Mountain Science 11(5):1342-1355. https://doi.org/10.1007/ $\underline{\text { s11629-014-3038-9 }}$

Yacoub, H. 2018. Knowledge and community resilience in rangelands recovery: the case of Wadi Allaqi Biosphere Reserve, South Eastern Desert, Egypt. Restoration Ecology 26:37-S43. https://doi.org/10.1111/rec.12667

Yager, K., C. Valdivia, D. Slayback, E. Jimenez, R. I. Meneses, A. Palabral, M. Bracho, D. Romero, A. Hubbard, P. Pacheco, A. Calle, et al. 2019. Socio-ecological dimensions of Andean pastoral landscape change: bridging traditional ecological knowledge and satellite image analysis in Sajama National Park, Bolivia. Regional Environmental Change 19(5):1353-1369. https://doi.org/10.1007/s10113-019-01466-y

Zent, S. 2013. Processual perspectives on traditional environmental knowledge: continuity, erosion, transformation, innovation. Pages 213-265 in R. Ellen, S. J. Lycett, and S. E. Johns, editors. Understanding cultural transmission in anthropology. Berghahn, New York, USA.

Zinsstag, J., M. Ould Taleb, and P. S. Craig. 2006. Health of nomadic pastoralists: new approaches towards equity effectiveness. Tropical Medicine \& International Health 11:565-568. https://doi.org/10.1111/j.1365-3156.2006.01615.x 
Table A1.1. All 288 papers reviewed (title and country to provide figure 2)

\begin{tabular}{|c|c|c|}
\hline $\begin{array}{l}\text { Paper's } \\
\text { code }\end{array}$ & Title & Country \\
\hline 115 & Conservation and monitoring of a persecuted African lion population by Maasai warriors & Kenya \\
\hline 140 & $\begin{array}{l}\text { Degradation and re-emergence of the commons: The impacts of government policies on traditional } \\
\text { resource management institutions in China }\end{array}$ & China \\
\hline 136 & $\begin{array}{l}\text { Drivers of forage availability: An integration of remote sensing and traditional ecological knowledge } \\
\text { in Karamoja sub-region, Uganda }\end{array}$ & Uganda \\
\hline 92 & $\begin{array}{l}\text { Ethnobotanical knowledge acquisition during daily chores: the firewood collection of pastoral } \\
\text { Maasai girls in Southern Kenya }\end{array}$ & Kenya \\
\hline 141 & $\begin{array}{l}\text { Forgetting fire:Traditional fire knowledge in two vchestnut forest ecosystems of the Iberian } \\
\text { Peninsula and its implications for European fire management policy }\end{array}$ & Spain \\
\hline 150 & $\begin{array}{l}\text { When Knowledge Follows Blood Kin Groups and the Distribution of Traditional Ecological } \\
\text { Knowledge in a Community of Seminomadic Pastoralists, Gujarat (India) }\end{array}$ & India \\
\hline 220 & $\begin{array}{l}\text { Pyrenean Pastoralists' Ecological Knowledge: Documentation and Application to Natural Resource } \\
\text { Management and Adaptation }\end{array}$ & Spain \\
\hline 105 & A comparison of traditional plant knowledge between students and herders in northern Kenya & Kenya \\
\hline 159 & $\begin{array}{l}\text { A shepherd has to invent: Poetic analysis of social-ecological change in the cultural landscape of the } \\
\text { central Spanish Pyrenees }\end{array}$ & Spain \\
\hline 31 & $\begin{array}{l}\text { Another vision of sound tree and forest management: Insights from traditional ash shaping in the } \\
\text { Moroccan Berber mountains }\end{array}$ & Morocco \\
\hline 101 & $\begin{array}{l}\text { Continuity and change within the social-ecological and political landscape of the Maasai Mara, } \\
\text { Kenya }\end{array}$ & Kenya \\
\hline 233 & $\begin{array}{l}\text { The Heterogeneity of Khumbu Sherpa Ecological Knowledge and Understanding in Sagarmatha } \\
\text { (Mount Everest) National Park and Buffer Zone, Nepal }\end{array}$ & Nepal \\
\hline 58 & $\begin{array}{l}\text { Traditional uses of medicinal plants used by Indigenous communities for veterinary practices at } \\
\text { Bajaur Agency, Pakistan }\end{array}$ & Pakistan \\
\hline 366 & The role of Mongolian nomadic pastoralists' ecological knowledge in rangeland management & Mongolia \\
\hline 315 & $\begin{array}{l}\text { Traditional ecological knowledge of a riverine forest in Turkana, Kenya: implications for research } \\
\text { and management }\end{array}$ & Kenya \\
\hline 282 & $\begin{array}{l}\text { Human ecology, ethnobotany and traditional practices in rural populations inhabiting the Monte } \\
\text { region: Resilience and ecological knowledge }\end{array}$ & Argentina \\
\hline 261 & $\begin{array}{l}\text { Indigenous knowledge related to climate variability and change: insights from droughts in semi-arid } \\
\text { areas of former Makueni District, Kenya }\end{array}$ & Kenya \\
\hline 212 & Traditional ecological knowledge among transhumant pastoralists in Mediterranean Spain & Spain \\
\hline 184 & $\begin{array}{l}\text { Traditional Ecological Knowledge in Europe: Status Quo and Insights for the Environmental Policy } \\
\text { Agenda }\end{array}$ & NA \\
\hline 182 & Perception and Management of Spatio-Temporal Pasture Heterogeneity by Hungarian Herders & Hungary \\
\hline 169 & Acacia trees on the cultural landscapes of the Red Sea Hills & $\begin{array}{l}\text { Egypt; } \\
\text { Sudan }\end{array}$ \\
\hline 281 & Arctic climate change discourse: the contrasting politics of research agendas in the West and Russia & Russia \\
\hline 133 & $\begin{array}{l}\text { Comigrants and friends: Informal networks and the transmission of traditional ecological knowledge } \\
\text { among seminomadic pastoralists of Gujarat, India }\end{array}$ & India \\
\hline 283 & Community participatory landscape classification and biodiversity assessment and monitoring of & Kenya \\
\hline
\end{tabular}




\begin{tabular}{|c|c|c|}
\hline & grazing lands in northern Kenya & \\
\hline 227 & $\begin{array}{l}\text { Ecological Conservation, Cultural Preservation, and a Bridge between: the Journey of Shanshui } \\
\text { Conservation Center in the Sanjiangyuan Region, Qinghai-Tibetan Plateau, China }\end{array}$ & China \\
\hline 183 & $\begin{array}{l}\text { Herder Observations of Rangeland Change in Mongolia: Indicators, Causes, and Application to } \\
\text { Community-Based Management }\end{array}$ & Mongolia \\
\hline 303 & $\begin{array}{l}\text { Herder Perceptions on Impacts of Range Enclosures, Crop Farming, Fire Ban and Bush } \\
\text { Encroachment on the Rangelands of Borana, Southern Ethiopia }\end{array}$ & Ethiopia \\
\hline 310 & $\begin{array}{l}\text { Learning from local knowledge: modeling the pastoral nomadic range management of the Himba, } \\
\text { Namibia }\end{array}$ & Namibia \\
\hline 11 & $\begin{array}{l}\text { Medicinal wild plants used by the Mongol herdsmen in Bairin Area of Inner Mongolia and its } \\
\text { comparative study between TMM and TCM }\end{array}$ & China \\
\hline 235 & $\begin{array}{l}\text { Reindeer management during the colonization of Sami lands: A long-term perspective of } \\
\text { vulnerability and adaptation strategies }\end{array}$ & Sweden \\
\hline \multirow[t]{2}{*}{228} & Tending for Cattle: Traditional Fire Management in Ethiopian Montane Heathlands & Ethiopia \\
\hline & The sacred and the scientific: traditional ecological knowledge in Siberian river conservation & Siberia \\
\hline 62 & $\begin{array}{l}\text { Through the lens of a herder: insights into landscape ethno-ecological knowledge on rangelands in } \\
\text { Namaqualand }\end{array}$ & South Africa \\
\hline 148 & $\begin{array}{l}\text { Oral traditional knowledge on medicinal plants in jeopardy among Gaddi shepherds in hills of } \\
\text { northwestern Himalaya, J\&K, India. }\end{array}$ & India \\
\hline 294 & Participatory monitoring of biodiversity in East African grazing lands & Uganda \\
\hline 165 & $\begin{array}{l}\text { Communal institutions for the management of rangeland resources and dairy production in Taleghan } \\
\text { Valley, Northern Iran }\end{array}$ & Iran \\
\hline 259 & $\begin{array}{l}\text { Remote Sensing and Local Knowledge of Hydrocarbon Exploitation: The Case of Bovanenkovo, } \\
\text { Yamal Peninsula, West Siberia, Russia }\end{array}$ & Siberia \\
\hline 4 & Indigenous knowledge for seasonal weather and climate forecasting across East Africa & $\begin{array}{l}\text { Ethiopia; } \\
\text { Tanzania; } \\
\text { Uganda }\end{array}$ \\
\hline 292 & Walking Behind the Old Women: Sacred Sakha Cow Knowledge in the 21st Century & Russia \\
\hline 363 & Assessments of landscape level degradation in southern Ethiopia: pastoralists versus ecologists & Ethiopia \\
\hline 289 & Indigenous Knowledge between Collapsion and Prospect of Genetic Conservation and Development & NA \\
\hline 175 & $\begin{array}{l}\text { Unexpected climate impacts on the Tibetan Plateau: Local and scientific knowledge in findings of } \\
\text { delayed summer }\end{array}$ & China \\
\hline 36 & $\begin{array}{l}\text { Inuit Approaches to Naming and Distinguishing Caribou: Considering Language, Place, and } \\
\text { Homeland toward Improved Co-management }\end{array}$ & Canada \\
\hline 180 & Efficacy of Two Lion Conservation Programs in Maasailand, Kenya & Kenya \\
\hline 325 & $\begin{array}{l}\text { Long-term Abundance Patterns of Barren-ground Caribou Using Trampling Scars on Roots of Picea } \\
\text { mariana in the Northwest Territories, Canada }\end{array}$ & Canada \\
\hline 286 & Traditional livelihood based on sheep grazing in the Khangchendzonga national park, Sikkim & India \\
\hline 48 & Analysis of observed and perceived climate change and variability in Arsi Negele District, Ethiopia & Ethiopia \\
\hline 181 & $\begin{array}{l}\text { Climate change and variability: perception and adaptation strategies of pastoralists and agro- } \\
\text { pastoralists across different zones of Burkina Faso }\end{array}$ & $\begin{array}{l}\text { Burkina } \\
\text { Faso }\end{array}$ \\
\hline 28 & $\begin{array}{l}\text { This country just hangs tight: perspectives on managing land degradation and climate change in far } \\
\text { west NSW }\end{array}$ & Australia \\
\hline 333 & An ethnobotanical survey of wild edible plants of Paphos and Larnaca countryside of Cyprus & Cyprus \\
\hline
\end{tabular}




\begin{tabular}{|c|c|c|}
\hline 176 & Traditional nomadic tending of trees in the Red Sea Hills & $\begin{array}{l}\text { Egypt; } \\
\text { Sudan }\end{array}$ \\
\hline 129 & $\begin{array}{l}\text { Rangeland degradation assessment: a new strategy based on the ecological knowledge of indigenous } \\
\text { pastoralists }\end{array}$ & Iran \\
\hline 278 & $\begin{array}{l}\text { Fulani Knowledge of the Ecological Impacts of Khaya senegalensis (Meliaceae) Foliage Harvest in } \\
\text { Benin and its Implications for Sustainable Harvest }\end{array}$ & Benin \\
\hline 19 & $\begin{array}{l}\text { Tibetan Lake Expansion from a Pastoral Perspective: Local Observations and Coping Strategies for a } \\
\text { Changing Environment }\end{array}$ & China \\
\hline 301 & $\begin{array}{l}\text { Integration of herder knowledge and ecological methods for land degradation assessment around } \\
\text { sedentary settlements in a sub-humid zone in northern Kenya }\end{array}$ & Kenya \\
\hline 214 & $\begin{array}{l}\text { Medicinal plants potential and use by pastoral and agro-pastoral communities in Erer Valley of } \\
\text { Babile Wereda, Eastern Ethiopia }\end{array}$ & Ethiopia \\
\hline 73 & $\begin{array}{l}\text { Reimagining invasions: The social and cultural impacts of Prosopis on pastoralists in southern Afar, } \\
\text { Ethiopia }\end{array}$ & Ethiopia \\
\hline 229 & The Shift from Herding to Hunting among the Siberian Evenki & Siberia \\
\hline 263 & $\begin{array}{l}\text { Riders under storms: Contributions of nomadic herders' observations to analysing climate change in } \\
\text { Mongolia }\end{array}$ & Mongolia \\
\hline 164 & $\begin{array}{l}\text { Turkana indigenous knowledge environmental sustainability and pastoralist lifestyle for economic } \\
\text { survival }\end{array}$ & Kenya \\
\hline 53 & $\begin{array}{l}\text { Knowledge and community resilience in rangelands recovery: the case of Wadi Allaqi Biosphere } \\
\text { Reserve, South Eastern Desert, Egypt }\end{array}$ & Egypt \\
\hline 280 & $\begin{array}{l}\text { Evaluation of Local Ecological Knowledge as a Method for Collecting Extensive Data on Animal } \\
\text { Abundance }\end{array}$ & Spain \\
\hline 80 & $\begin{array}{l}\text { Climate Change and Variability in Semiarid Palapye, Eastern Botswana: An Assessment from } \\
\text { Smallholder Farmers' Perspective }\end{array}$ & Botswana \\
\hline 252 & Assessing Resource Dependency on the Rangelands as a Measure of Climate Sensitivity & Australia \\
\hline 35 & $\begin{array}{l}\text { From traditional knowledge to novel adaptations of transhumant pastoralists the in face of new } \\
\text { challenges in North Patagonia }\end{array}$ & Argentina \\
\hline 91 & $\begin{array}{l}\text { Exploring local knowledge and perceptions on zoonoses among pastoralists in northern and eastern } \\
\text { Tanzania }\end{array}$ & Tanzania \\
\hline 226 & $\begin{array}{l}\text { Pastoralists' Perception and Ecological Knowledge on Savanna Ecosystem Dynamics in Semi-arid } \\
\text { Botswana }\end{array}$ & Botswana \\
\hline 67 & $\begin{array}{l}\text { Contested understandings of yaks on the eastern Tibetan Plateau: market logic, Tibetan Buddhism } \\
\text { and indigenous knowledge }\end{array}$ & China \\
\hline 260 & $\begin{array}{l}\text { Linking local ecological knowledge and habitat modelling to predict absolute species abundance on } \\
\text { large scales }\end{array}$ & Spain \\
\hline 143 & $\begin{array}{l}\text { Misreading the Arctic landscape:Apolitical ecology of reindeer, carrying capacities, and } \\
\text { overstocking in Finnmark, Norway }\end{array}$ & Norway \\
\hline 111 & Communication for the development of pastoralism & \\
\hline 323 & $\begin{array}{l}\text { Behaviour of goats, sheep and cattle and their selection of browse species on natural pasture in a } \\
\text { Sahelian area }\end{array}$ & $\begin{array}{l}\text { Burkina } \\
\text { Faso }\end{array}$ \\
\hline 94 & Himalayan Grasslands: Indigenous Knowledge and Institutions for Social Innovation & $\begin{array}{l}\text { China; India; } \\
\text { Nepal }\end{array}$ \\
\hline 331 & $\begin{array}{l}\text { Use of participatory epidemiology to compare the clinical veterinary knowledge of pastoralists and } \\
\text { veterinarians in East Africa }\end{array}$ & $\begin{array}{l}\text { Sudan; } \\
\text { Kenya }\end{array}$ \\
\hline 119 & The use of indigenous climate forecasting methods by the pastoralists of Northern Kenya & Kenya \\
\hline
\end{tabular}




\begin{tabular}{|c|c|c|}
\hline 318 & $\begin{array}{l}\text { Tracking wildebeest, locating knowledge: Maasai and conservation biology understandings of } \\
\text { wildebeest behavior in Northern Tanzania }\end{array}$ & Tanzania \\
\hline 132 & $\begin{array}{l}\text { Integrating local pastoral knowledge, participatory mapping, and species distribution modeling for } \\
\text { risk assessment of invasive rubber vine (Cryptostegia grandiflora) in Ethiopia's Afar region }\end{array}$ & Ethiopia \\
\hline 102 & $\begin{array}{l}\text { Community perceptions on spatio-temporal land use changes in the Amboseli ecosystem, southern } \\
\text { Kenya }\end{array}$ & Kenya \\
\hline 322 & $\begin{array}{l}\text { Indigenous rangeland resource management in the mountainous areas of northern Nepal: a case study } \\
\text { from the Rasuwa District }\end{array}$ & Nepal \\
\hline 199 & $\begin{array}{l}\text { Wild plant folk nomenclature of the Mongol herdsmen in the Arhorchin national nature reserve, } \\
\text { Inner Mongolia, PR China }\end{array}$ & China \\
\hline 240 & Human stewardship or ruining cultural landscapes of the ancient Tula wells, southern Ethiopia & Ethiopia \\
\hline 87 & Alignment between values of dryland pastoralists and conservation needs for small mammals. & Australia \\
\hline 268 & Origins of Travelling Stock Routes. 1. Connections to Indigenous traditional pathways & Australia \\
\hline 97 & Collaborative processes for exploring rural futures: The Exploring Futures Platform & $\begin{array}{l}\text { New } \\
\text { Zealand }\end{array}$ \\
\hline 272 & $\begin{array}{l}\text { Viewing Change Through the Prism of Indigenous Human Ecology: Findings from the Afghan and } \\
\text { Tajik Pamirs }\end{array}$ & $\begin{array}{l}\text { Afghanistan; } \\
\text { Tajikistan }\end{array}$ \\
\hline 107 & $\begin{array}{l}\text { Coupled Socio-Environmental Changes Triggered Indigenous Aymara Depopulation of the Semiarid } \\
\text { Andes of Tarapacá-Chile during the Late 19th-20th Centuries }\end{array}$ & Chile \\
\hline 130 & $\begin{array}{l}\text { Local knowledge production, transmission, and the importance of village leaders in a network of } \\
\text { Tibetan pastoralists coping with environmental change }\end{array}$ & China \\
\hline 147 & Ethnoveterinary of Sahrawi pastoralists of Western Sahara: camel diseases and remedies & $\begin{array}{l}\text { Algeria; } \\
\text { Mauritania; } \\
\text { Morocco }\end{array}$ \\
\hline 25 & $\begin{array}{l}\text { Forest Fire and Indigenous Sami Land Use: Place Names, Fire Dynamics, and Ecosystem Change in } \\
\text { Northern Scandinavia }\end{array}$ & Sweden \\
\hline 114 & Meadow up a tree: Feeding flocks with a native ash tree in the Moroccan mountains & Morocco \\
\hline 284 & $\begin{array}{l}\text { Institutional development for sustainable rangeland resource and ecosystem management in } \\
\text { mountainous areas of northern Nepal }\end{array}$ & Nepal \\
\hline 300 & $\begin{array}{l}\text { The effect of development interventions on the use of indigenous range management strategies in the } \\
\text { Borana Lowlands in Ethiopia }\end{array}$ & Ethiopia \\
\hline 85 & $\begin{array}{l}\text { Species composition determines forage quality and medicinal value of high diversity grasslands in } \\
\text { lowland England }\end{array}$ & England \\
\hline 65 & $\begin{array}{l}\text { Exploring knowledge and management practices on ticks and tick-borne diseases among agro- } \\
\text { pastoral communities in Southern Highlands, Tanzania }\end{array}$ & Tanzania \\
\hline 234 & The impact of agro-pastoral abandonment on the Rock Partridge Alectoris graeca in the Apennines & Italy \\
\hline 262 & $\begin{array}{l}\text { Learning the indigenous knowledge and biodiversity through contest: A participatory methodological } \\
\text { tool of ecoliteracy }\end{array}$ & India \\
\hline 210 & $\begin{array}{l}\text { Ethno-veterinary practices for ephemeral fever of Yak: A participatory assessment by the Monpa } \\
\text { tribe of Arunachal Pradesh }\end{array}$ & India \\
\hline 330 & Indigenous ecological knowledge of Borana pastoralists in southern Ethiopia and current challenges & Ethiopia \\
\hline 238 & Husbandry practices of El-Kababish camel herders: case study north Kordofan State, Sudan & Sudan \\
\hline 86 & Husbandry practices of El-Kababish camel herders: case study north Kordofan State, Sudan & Lesotho \\
\hline 201 & $\begin{array}{l}\text { Derivation of a household-level vulnerability index for empirically testing measures of adaptive } \\
\text { capacity and vulnerability }\end{array}$ & Mozambique \\
\hline
\end{tabular}




\begin{tabular}{|c|c|c|}
\hline 47 & Climate change and cultural heritage in western Mongolia & Mongolia \\
\hline 90 & $\begin{array}{l}\text { Collecting Ophiocordyceps sinensis: an emerging livelihood strategy in the Garhwal, Indian } \\
\text { Himalaya }\end{array}$ & India \\
\hline 178 & $\begin{array}{l}\text { The interplay of knowledge, attitude and practice of livestock farmers' land management against } \\
\text { desertification in the South African Kalahari }\end{array}$ & South Africa \\
\hline 209 & The good shepherd: remedying the fencing syndrome & South Africa \\
\hline 204 & $\begin{array}{l}\text { 'Everybody knows', but the rest of the world: the case of a caterpillar-borne reproductive loss } \\
\text { syndrome in dromedary camels observed by Sahrawi pastoralists of Western Sahara }\end{array}$ & $\begin{array}{l}\text { Mauritania; } \\
\text { Algeria }\end{array}$ \\
\hline 223 & $\begin{array}{l}\text { Accuracy of pastoralists' memory-based kinship assignment of Ankole cattle: a microsatellite DNA } \\
\text { analysis }\end{array}$ & Uganda \\
\hline 45 & $\begin{array}{l}\text { Grazing and rangeland management: Trans-human adaptations by Brokpa community in fragile } \\
\text { ecosystems of Arunachal Pradesh }\end{array}$ & India \\
\hline 9 & $\begin{array}{l}\text { Adaptation to climate change using indigenous weather forecasting systems in Borana pastoralists of } \\
\text { southern Ethiopia }\end{array}$ & Ethiopia \\
\hline 302 & Livestock grazing behaviour along a degradation gradient in the Somali region of eastern Ethiopia & Ethiopia \\
\hline 146 & Ethnoveterinary medicines used by goat keepers in Marwar region of Rajasthan, India & India \\
\hline 3 & $\begin{array}{l}\text { Local Knowledge for Addressing Food Insecurity: The Use of a Goat Meat Drying Technique in a } \\
\text { Rural Famine Context in Southern Africa }\end{array}$ & Mozambique \\
\hline 277 & $\begin{array}{l}\text { Efficacy of Integrating Herder Knowledge and Ecological Methods for Monitoring Rangeland } \\
\text { Degradation in Northern Kenya }\end{array}$ & Kenya \\
\hline 256 & $\begin{array}{l}\text { Quantitative ethnobotany of medicinal plants used by Kara and Kwego semi-pastoralist people in } \\
\text { lower Omo River Valley, Debub Omo Zone, Southern Nations, Nationalities and Peoples Regional } \\
\text { State, Ethiopia }\end{array}$ & Ethiopia \\
\hline 314 & $\begin{array}{l}\text { Pastoralists' perceptions and realities of vegetation change and browse consumption in the northern } \\
\text { Kalahari, Namibia }\end{array}$ & Namibia \\
\hline 258 & $\begin{array}{l}\text { Ethnoveterinary treatments by dromedary camel herders in the Suleiman Mountainous Region in } \\
\text { Pakistan: an observation and questionnaire study }\end{array}$ & Pakistan \\
\hline 41 & $\begin{array}{l}\text { In the light of change: a mixed methods investigation of climate perceptions and the instrumental } \\
\text { record in northern Sweden }\end{array}$ & Sweden \\
\hline 32 & Turning the herding lifestyle into a learning opportunity: Experiences from Lesotho & Lesotho \\
\hline 34 & $\begin{array}{l}\text { Investigating criteria for valuation of forage resources by local agro-pastoralists in West Africa: } \\
\text { using quantitative ethnoecological approach }\end{array}$ & $\begin{array}{l}\text { Ghana; } \\
\text { Burkina } \\
\text { Faso }\end{array}$ \\
\hline 81 & $\begin{array}{l}\text { Can pastoral communities offer solutions for conserving the Endangered Grevy's zebra Equus } \\
\text { grevyi at the periphery of its range? }\end{array}$ & Kenya \\
\hline 177 & $\begin{array}{l}\text { Past and Present Winter Feeding of Reindeer in Finland: Herders' Adaptive Learning of Feeding } \\
\text { Practices }\end{array}$ & Finland \\
\hline 43 & Ethnomedicinal applications of animal species by the local communities of Punjab, Pakistan & Pakistan \\
\hline 338 & Plant Biodiversity and Ethnobotany of Borana Pastoralists in Southern Oromia, Ethiopia & Ethiopia \\
\hline 104 & $\begin{array}{l}\text { Changing year-round habitat use of extensively grazing cattle, sheep and pigs in East-Central Europe } \\
\text { between } 1940 \text { and 2014: Consequences for conservation and policy }\end{array}$ & $\begin{array}{l}\text { Hungary; } \\
\text { Croatia; } \\
\text { Serbia; } \\
\text { Romania; } \\
\text { Ukraine; } \\
\text { Slovakia }\end{array}$ \\
\hline
\end{tabular}




\begin{tabular}{|c|c|c|}
\hline 161 & $\begin{array}{l}\text { Local perceptions of rangeland degradation and climate change in the pastoral society of Qinghai- } \\
\text { Tibetan Plateau }\end{array}$ & China \\
\hline 222 & $\begin{array}{l}\text { Pastoralists' indigenous selection criteria and other breeding practices of the long-horned Ankole } \\
\text { cattle in Uganda }\end{array}$ & Uganda \\
\hline 63 & $\begin{array}{l}\text { Feeding flocks on rangelands: insights into the local ecological knowledge of shepherds in } \\
\text { Boulemane province (Morocco) }\end{array}$ & Morocco \\
\hline 15 & $\begin{array}{l}\text { Knowledge, perceptions and experiences of trachoma among Maasai in Tanzania: Implications for } \\
\text { prevention and control }\end{array}$ & Tanzania \\
\hline 44 & $\begin{array}{l}\text { Ethnobotanical knowledge of pastoral community for treating livestock diseases in Somali regional } \\
\text { state, eastern Ethiopia }\end{array}$ & Ethiopia \\
\hline 296 & Understanding pastoral mobility: the case of Senegalese Fulani & Senegal \\
\hline 123 & Information sharing and climate risk management among Senegalese agropastoralists & Senegal \\
\hline 71 & $\begin{array}{l}\text { Rabari shepherds and the mad tree: the dynamics of local ecological knowledge in the context of } \\
\text { Prosopis Juliflora invasion in Gujarat, India }\end{array}$ & India \\
\hline 361 & $\begin{array}{l}\text { An Institutionalized Human-Animal Relationship and the Aftermath: The Reproductive Process of } \\
\text { Horse-Bands and Husbandry in Northern Yakutia, Siberia }\end{array}$ & Siberia \\
\hline 162 & $\begin{array}{l}\text { Paisang (Quercus griffithii): A Keystone Tree Species in Sustainable Agroecosystem Management } \\
\text { and Livelihoods in Arunachal Pradesh, India }\end{array}$ & India \\
\hline 349 & $\begin{array}{l}\text { Mapping land cover change in a reindeer herding area of the Russian Arctic using Landsat TM and } \\
\text { ETM+ imagery and indigenous knowledge }\end{array}$ & Russia \\
\hline 78 & $\begin{array}{l}\text { Herders' ecological knowledge and carnivore predation on livestock investigations in Makgadikgadi } \\
\text { and Nxai Read online: Scan this QR code with your smart phone or mobile device to read online. } \\
\text { national parks, Botswana }\end{array}$ & Botswana \\
\hline 358 & Linking Local Perceptions of Elephants and Conservation: Samburu Pastoralists in Northern Kenya & Kenya \\
\hline 179 & Female Camel Nomenclature among Arabia's Bedouins & Oman \\
\hline 75 & $\begin{array}{l}\text { Historical perspectives on pastoralism and land tenure transformation in Ngamiland, Botswana: } \\
\text { What are the policy and institutional lessons }\end{array}$ & Botswana \\
\hline 22 & $\begin{array}{l}\text { Ethnobotanical knowledge among the semi-pastoral Gujjar tribe in the high altitude (Adhwari's) of } \\
\text { Churah subdivision, district Chamba, Western Himalaya }\end{array}$ & India \\
\hline 231 & $\begin{array}{l}\text { Predicting the distribution of cryptic species: the case of the spur-thighed tortoise in Andalusia } \\
\text { (southern Iberian Peninsula) }\end{array}$ & Spain \\
\hline 196 & $\begin{array}{l}\text { The importance of being reliable e Local ecological knowledge and management of forage plants in a } \\
\text { dryland pastoral system (Morocco) }\end{array}$ & Morocco \\
\hline 326 & $\begin{array}{l}\text { Comparison of production systems and selection criteria of Ankole cattle by breeders in Burundi, } \\
\text { Rwanda, Tanzania and Uganda }\end{array}$ & $\begin{array}{l}\text { Burundi; } \\
\text { Rwanda; } \\
\text { Tanzania; } \\
\text { Uganda }\end{array}$ \\
\hline 218 & Uses and management of Ximenia americana, Olacaceae in semi-arid east Shewa, Ethiopia & Ethiopia \\
\hline 88 & $\begin{array}{l}\text { Factors influencing local ecological knowledge of forage resources: Ethnobotanical evidence from } \\
\text { West Africa's savannas }\end{array}$ & $\begin{array}{l}\text { Ghana; } \\
\text { Burkina } \\
\text { Faso }\end{array}$ \\
\hline 72 & $\begin{array}{l}\text { Wolf and Bear Depredation on Livestock in Northern Sweden 1827-2014: Combining History, } \\
\text { Ecology and Interviews }\end{array}$ & Sweden \\
\hline 125 & $\begin{array}{l}\text { Coping with difficult weather and snow conditions: Reindeer herders' views on climate change } \\
\text { impacts and coping strategies }\end{array}$ & \begin{tabular}{|l} 
Finland \\
\end{tabular} \\
\hline
\end{tabular}




\begin{tabular}{|c|c|c|}
\hline 186 & The social nature of environmental knowledge among the nomadic Wodaabe of Niger & Niger \\
\hline 70 & $\begin{array}{l}\text { "I See the Grass Through the Mouths of My Animals" - Folk Indicators of Pasture Plants Used by } \\
\text { Traditional Steppe Herders }\end{array}$ & Hungary \\
\hline 378 & Gender, indigenous knowledge, and pastoral resource use in Morocco & Morocco \\
\hline 352 & Traditional cattle-husbandry systems in Eritrea: cattle-man relationships & Eritrea \\
\hline 298 & $\begin{array}{l}\text { Towards Endogenous Livestock Development: Borana Pastoralists' Responses to Environmental and } \\
\text { Institutional Changes }\end{array}$ & Ethiopia \\
\hline 1 & $\begin{array}{l}\text { Ethnoveterinary remedies used in the Algerian steppe: Exploring the relationship with traditional } \\
\text { human herbal medicine }\end{array}$ & Algeria \\
\hline 2 & $\begin{array}{l}\text { Climate change has more adverse impacts on the higher mountain communities than the lower ones: } \\
\text { people's perception from the northern Himalayas }\end{array}$ & China \\
\hline 6 & Songs, Settings, Sociality: Human and Ecological Well-being in Western Mongolia & Mongolia \\
\hline 7 & Like a Lullaby: Song as Herding Tool in Rural Mongolia & Mongolia \\
\hline 10 & $\begin{array}{l}\text { Seasonal fire management by traditional cattle ranchers prevents the spread of wildfire in the } \\
\text { Brazilian Cerrado }\end{array}$ & Brazil \\
\hline 12 & $\begin{array}{l}\text { Nomads' indigenous knowledge and their adaptation to climate changes in Semirom City in Central } \\
\text { Iran }\end{array}$ & Iran \\
\hline 13 & $\begin{array}{l}\text { Opportunities to integrate herders' indicators into formal rangeland monitoring: an example from } \\
\text { Mongolia }\end{array}$ & Mongolia \\
\hline 14 & $\begin{array}{l}\text { Integrating Traditional Ecological Knowledge and Remote Sensing for Monitoring Rangeland } \\
\text { Dynamics in the Altai Mountain Region }\end{array}$ & $\begin{array}{l}\text { Mongolia; } \\
\text { Russia; } \\
\text { China; } \\
\text { Kazakhstan }\end{array}$ \\
\hline 16 & $\begin{array}{l}\text { Socio-ecological dimensions of Andean pastoral landscape change: bridging traditional ecological } \\
\text { knowledge and satellite image analysis in Sajama National Park, Bolivia }\end{array}$ & Bolivia \\
\hline 17 & $\begin{array}{l}\text { Indigenous weather and climate forecasting knowledge among Afar pastoralists of north eastern } \\
\text { Ethiopia: Role in adaptation to weather and climate variability }\end{array}$ & Ethiopia \\
\hline 20 & $\begin{array}{l}\text { Reindeer Herders Without Reindeer. The Challenges of Joint Knowledge Production on Kolguev } \\
\text { Island in the Russian Arctic }\end{array}$ & Russia \\
\hline 21 & $\begin{array}{l}\text { Traditional and local knowledge in land use planning: insights into the use of the Akwé: Kon } \\
\text { Guidelines in Eanodat, Finnish Sápmi }\end{array}$ & Finland \\
\hline 23 & $\begin{array}{l}\text { Local agro-pastoralists' perspectives on forage species diversity, habitat distributions, abundance } \\
\text { trends and ecological drivers for sustainable livestock production in West Afric }\end{array}$ & $\begin{array}{l}\text { Ghana; } \\
\text { Burkina } \\
\text { Faso }\end{array}$ \\
\hline 24 & $\begin{array}{l}\text { Indigenous knowledge practices for sustainable lifelong education in pastoralist communities of } \\
\text { Kenya }\end{array}$ & Kenya \\
\hline 27 & $\begin{array}{l}\text { The effect of climate information in pastoralists' adaptation to climate change A case study of } \\
\text { Rwenzori region, Western Uganda }\end{array}$ & Uganda \\
\hline 29 & $\begin{array}{l}\text { Health risk perceptions and local knowledge of water-related infectious disease exposure among } \\
\text { Kenyan wetland communities }\end{array}$ & Kenya \\
\hline 30 & $\begin{array}{l}\text { Shepherds' local knowledge and scientific data on the scavenging ecosystem service: Insights for } \\
\text { conservation }\end{array}$ & Spain \\
\hline 37 & $\begin{array}{l}\text { Merging Indigenous Knowledge Systems and Station Observations to Estimate the Uncertainty of } \\
\text { Precipitation Change in Central Mongolia }\end{array}$ & Mongolia \\
\hline 46 & $\begin{array}{l}\text { Increasing the Local Relevance of Epidemiological Research: Situated Knowledge of Cattle Disease } \\
\text { Among Basongora Pastoralists in Uganda }\end{array}$ & Uganda \\
\hline
\end{tabular}




\begin{tabular}{|c|c|c|}
\hline 51 & Traditional ecological knowledge underlying herding decisions of pastoralists & Benin \\
\hline 52 & Understanding roles and functions of cattle breeds for pastoralists in Benin & Benin \\
\hline 54 & $\begin{array}{l}\text { Integrating indigenous local knowledge and species distribution modeling to detect wildlife in } \\
\text { Somaliland }\end{array}$ & Somalia \\
\hline 57 & Factors Affecting Sustainable Animal Trypanosomosis Control in Parts of Kaduna State, Nigeria & Nigeria \\
\hline 59 & $\begin{array}{l}\text { The relevance of herders' local ecological knowledge on coping with livestock losses during harsh } \\
\text { winters in western Mongolia }\end{array}$ & Mongolia \\
\hline 68 & Integrating remote sensing and local ecological knowledge to monitor rangeland dynamics & Kyrgyzstan \\
\hline 69 & $\begin{array}{l}\text { Important knowledge gaps among pastoralists on causes and treatment of udder health problems in } \\
\text { livestock in southern Ethiopia: results of qualitative investigation }\end{array}$ & Ethiopia \\
\hline 74 & Medicinal and commercial uses of ostrich products in Tanzania & Tanzania \\
\hline 76 & Botanical ethnoveterinary therapies used by agro-pastoralists of Fafan zone, Eastern Ethiopia & Ethiopia \\
\hline 77 & $\begin{array}{l}\text { Distribution and socio-ecological impacts of the invasive alien cactus Opuntia stricta in eastern } \\
\text { Africa }\end{array}$ & Kenya \\
\hline 79 & $\begin{array}{l}\text { An ethnobotanical survey of medicinal and edible plants of Yalo Woreda in Afar regional state, } \\
\text { Ethiopia }\end{array}$ & Ethiopia \\
\hline 82 & Basotho herders learn through culture and social interaction & Lesotho \\
\hline 83 & $\begin{array}{l}\text { From Herders to Wage Laborers and Back Again: Engaging with Capitalism in the Atacama Puna } \\
\text { Region of Northern Chile }\end{array}$ & Chile \\
\hline 89 & $\begin{array}{l}\text { Indigenous Control Methods for Parasites among Pastoralists Communities in Adamawa State, } \\
\text { Nigeria }\end{array}$ & Nigeria \\
\hline 96 & The future of pastoralism/L'avenir du pastoralisme/El futuro del pastoreo & NA \\
\hline 98 & $\begin{array}{l}\text { Tibetan Buddhism, Wetland Transformation, and Environmentalism in Tibetan Pastoral Areas of } \\
\text { Western China }\end{array}$ & China \\
\hline 103 & $\begin{array}{l}\text { Indigenous ecological knowledge as the basis for adaptive environmental management: Evidence } \\
\text { from pastoralist communities in the Horn of Africa }\end{array}$ & Ethiopia \\
\hline 106 & $\begin{array}{l}\text { Tracing innovation pathways in the management of natural and social capital on Laikipia Maasai } \\
\text { Group Ranches, Kenya }\end{array}$ & Kenya \\
\hline 112 & Indigenous knowledge of pastoralists on respiratory diseases ofcamels in northern Kenya & Kenya \\
\hline 116 & $\begin{array}{l}\text { Transhumant Pastoralism in the Context of Socioeconomic and Climate Change in the Mountains of } \\
\text { Nepal }\end{array}$ & Nepal \\
\hline 117 & $\begin{array}{l}\text { Evolution of models to support community and policy action with science: Balancing pastoral } \\
\text { livelihoods and wildlife conservation in savannas of East Africa }\end{array}$ & $\begin{array}{l}\text { Ethiopia; } \\
\text { Kenya }\end{array}$ \\
\hline 118 & $\begin{array}{l}\text { Herding conditions related to infectious keratoconjunctivitis in semi-domesticated reindeer: a } \\
\text { questionnaire-based survey among reindeer herders }\end{array}$ & $\begin{array}{l}\text { Sweden; } \\
\text { Norway }\end{array}$ \\
\hline 120 & $\begin{array}{l}\text { Broad-scale assumptions on available pasture resources and reindeer's habitat preferences shown to } \\
\text { be decoupled from ecological reality of Arctic-alpine landscapes }\end{array}$ & Norway \\
\hline 121 & Are trees of intermediate densitymore facilitative? Canopy effects of four East African legume trees & Ethiopia \\
\hline 122 & $\begin{array}{l}\text { Sharing local ecological knowledge as a human adaptation strategy to arid environments: Evidence } \\
\text { from an ethnobotany survey in Morocco }\end{array}$ & Morocco \\
\hline 126 & Resilience of small-scale societies: a view from drylands & NA \\
\hline 127 & Strengths and weaknesses of traditional feeding management of dairy goat farms in mountain areas & Spain \\
\hline 128 & Terra Nullius: Colonial Violence in Prynne’s Acrylic Tips & Australia \\
\hline 134 & Pastoral livelihoods under pressure: Ecological, political and socioeconomic transitions in Afar & Ethiopia \\
\hline
\end{tabular}




\begin{tabular}{|c|c|c|}
\hline & (Ethiopia) & \\
\hline 135 & $\begin{array}{l}\text { Morels of Palas Valley, Pakistan: A Potential Source for Generating Income and Improving } \\
\text { Livelihoods of Mountain Communities }\end{array}$ & Pakistan \\
\hline 137 & An ethnobotany of the Lukomir Highlanders of Bosnia \& Herzegovina & $\begin{array}{l}\text { Bosnia and } \\
\text { Herzegovina }\end{array}$ \\
\hline 139 & $\begin{array}{l}\text { Wood-pastures of Europe: Geographic coverage, social-ecological values, conservation } \\
\text { management, and policy implications }\end{array}$ & Europe \\
\hline 142 & $\begin{array}{l}\text { Loss of traditional knowledge aggravates wolf-human conflict in Georgia (Caucasus) in the wake of } \\
\text { socio-economic change }\end{array}$ & Georgia \\
\hline 144 & $\begin{array}{l}\text { Persistence of Two Small Antelope Species in the Degraded Mutara Rangelands (Akagera } \\
\text { Ecosystem) Based on Pastoralists' and Farmers' Perceptions }\end{array}$ & $\begin{array}{l}\text { Rwanda; } \\
\text { Tanzania; } \\
\text { Uganda }\end{array}$ \\
\hline 153 & $\begin{array}{l}\text { Sámi reindeer herders' perspective on herbivory of subarctic mountain birch forests by geometrid } \\
\text { moths and reindeer: a case study from northernmost Finland }\end{array}$ & Finland \\
\hline 154 & Climate Change and Rural Livelihoods -adaptation and vulnerability in Rajasthan & Pakistan \\
\hline 157 & $\begin{array}{l}\text { A study of medicinal plants used as ethnoveterinary: harnessing potential phytotherapy in Bheri, } \\
\text { District Muzaffarabad (Pakistan) }\end{array}$ & Pakistan \\
\hline 158 & $\begin{array}{l}\text { Trees dynamics (1955-2012) and their uses in the Senegal's Ferlo region: insights from a historical } \\
\text { vegetation database, local knowledge and field inventories }\end{array}$ & Senegal \\
\hline 168 & Traditional knowledge of wild food plants in a few Tibetan communities & $\begin{array}{l}\text { India; China; } \\
\text { Nepal }\end{array}$ \\
\hline 171 & $\begin{array}{l}\text { Relationship Between Pastoralists' Evaluation of Rangeland State and Vegetation Threshold } \\
\text { Changes in Mongolian Rangelands }\end{array}$ & Mongolia \\
\hline 173 & Herding strategies during a drought vary at multiple scales in Mongolian rangeland & Mongolia \\
\hline 174 & $\begin{array}{l}\text { Livelihood Diversification as an Adaptation Approach to Change in the Pastoral Hindu-Kush } \\
\text { Himalayan Region }\end{array}$ & $\begin{array}{l}\text { Afghanistan; } \\
\text { Bhutan; } \\
\text { China; India; } \\
\text { Nepal; } \\
\text { Pakistan }\end{array}$ \\
\hline 189 & Ethnoveterinary knowledge of Raikas of Marwar for nomadic pastoralism & India \\
\hline 192 & $\begin{array}{l}\text { Working Knowledge: characterising collective indigenous, scientific, and local knowledge about the } \\
\text { ecology, hydrology and geomorphology of Oriners Station, Cape York Peninsula, Australia }\end{array}$ & Australia \\
\hline 194 & $\begin{array}{l}\text { Adaptation of herders to droughts and privatization of rangeland-use rights in the arid Alxa Left } \\
\text { Banner of Inner Mongolia }\end{array}$ & China \\
\hline 195 & Herders' Perceptions of and Responses to Climate Change in Northern Pakistan & Pakistan \\
\hline 197 & $\begin{array}{l}\text { Traditional vegetation knowledge of the Hortobágy salt steppe (Hungary): a neglected source of } \\
\text { information for vegetation science and conservation }\end{array}$ & Hungary \\
\hline 198 & Sustainable Rangeland Management: Pastoralists' attitudes toward integrated programs in Iran & Iran \\
\hline 200 & $\begin{array}{l}\text { The role of drought among agro-pastoral communities in a semi-arid environment: The case of } \\
\text { Botswana }\end{array}$ & Botswana \\
\hline 203 & $\begin{array}{l}\text { Ethnobotanical study of plants used in management of livestock health problems by Afar people of } \\
\text { Ada'ar District, Afar Regional State, Ethiopia }\end{array}$ & Ethiopia \\
\hline 206 & $\begin{array}{l}\text { Pastoralists' knowledge of plant palatability and grazing indicators in an arid region of South } \\
\text { Australia }\end{array}$ & Australia \\
\hline 207 & Ethno-veterinary practices amongst livestock farmers in Ngamiland District, Botswana & Botswana \\
\hline
\end{tabular}




\begin{tabular}{|c|c|c|}
\hline 208 & $\begin{array}{l}\text { Envisioning the future of transhumant pastoralism through participatory scenario planning: a case } \\
\text { study in Spain }\end{array}$ & Spain \\
\hline 211 & $\begin{array}{l}\text { The Role of Indigenous Ecological Knowledge in Managing Rangelands Sustainably in Northern } \\
\text { Iran }\end{array}$ & Iran \\
\hline 213 & $\begin{array}{l}\text { Pastoralists' perceptions of biodiversity and land management strategies in the arid Stony Plains } \\
\text { region of South Australia: Implications for policy makers }\end{array}$ & Australia \\
\hline 215 & Traditional coping mechanisms for climate change of pastoralists in South Omo, Ethiopia & Ethiopia \\
\hline 216 & $\begin{array}{l}\text { Climate Change Adaptation Among Tibetan Pastoralists: Challenges in Enhancing Local Adaptation } \\
\text { Through Policy Support }\end{array}$ & China \\
\hline 219 & Pasture use and management strategies in the Ankole pastoral system in Uganda & Uganda \\
\hline 221 & $\begin{array}{l}\text { Ethnoknowledge of Bukusu community on livestock tick prevention and control in Bungoma district, } \\
\text { western Kenya }\end{array}$ & Kenya \\
\hline 224 & Febrile illness experience among Nigerian nomads & Nigeria \\
\hline 225 & $\begin{array}{l}\text { "I'd Be Foolish to Tell You They Were Caribou": Local Knowledge of Historical Interactions } \\
\text { between Reindeer and Caribou in Barrow, Alaska. }\end{array}$ & $\begin{array}{l}\text { United } \\
\text { States }\end{array}$ \\
\hline 236 & Challenges of assessing the sustainability of (agro)-pastoral systems & $\begin{array}{l}\text { Kenya; } \\
\text { Niger }\end{array}$ \\
\hline 237 & $\begin{array}{l}\text { Sámi traditional ecological knowledge as a guide to science: snow, ice and reindeer pasture facing } \\
\text { climate change }\end{array}$ & Sweden \\
\hline 239 & $\begin{array}{l}\text { Resonance Strategies of Sámi Reindeer Herders in Northernmost Finland during Climatically } \\
\text { Extreme Years }\end{array}$ & Finland \\
\hline 241 & Seasonal precipitation forecasts: Agro-ecological knowledge among rural Kalahari communities & Botswana \\
\hline 245 & $\begin{array}{l}\text { Impacts of Arctic Climate and Land Use Changes on Reindeer Pastoralism: Indigenous Knowledge } \\
\text { and Remote Sensing }\end{array}$ & NA \\
\hline 247 & Gums and resins: The potential for supporting sustainable adaptation in Kenya's drylands & Kenya \\
\hline 248 & $\begin{array}{l}\text { Landscape change in the lower Omo valley, southwestern Ethiopia: burning patterns and woody } \\
\text { encroachment in the savanna }\end{array}$ & Ethiopia \\
\hline 249 & $\begin{array}{l}\text { Doing is Learning: Analysis of an Unsuccessful Attempt to Adapt TEK/ IK Methodology to } \\
\text { Norwegian Sa'mi Circumstances }\end{array}$ & Norway \\
\hline 250 & $\begin{array}{l}\text { Cultural dimension of wolves in the Iberian Peninsula: implications of ethnozoology in conservation } \\
\text { biology }\end{array}$ & $\begin{array}{l}\text { Portugal; } \\
\text { Spain }\end{array}$ \\
\hline 264 & Combining facilitated dialogue and spatial data analysis to compile landscape history & Australia \\
\hline 269 & $\begin{array}{l}\text { Traditional Ecological Knowledge Informing Resource Management: Saxoul Conservation in Inner } \\
\text { Mongolia, China }\end{array}$ & China \\
\hline 270 & $\begin{array}{l}\text { Traditional rangeland resource utilisation practices and pastoralists' perceptions on land degradation } \\
\text { in south-east Ethiopia }\end{array}$ & Ethiopia \\
\hline 275 & Of forest, snow and lichen: Sami reindeer herders' knowledge of winter pastures in northern Sweden & Sweden \\
\hline 276 & $\begin{array}{l}\text { Indigenous yak and yak-cattle crossbreed management in high altitude areas of northern Nepal: A } \\
\text { case study from Rasuwa district }\end{array}$ & Nepal \\
\hline 279 & Partnering with local communities to identify conservation priorities for endangered Grevy's zebra & Kenya \\
\hline 287 & Traditional fire management: historical fire regimes and land use change in pastoral East Africa & Tanzania \\
\hline 291 & Botanical Knowledge and its Differentiation by Age, Gender and Ethnicity in Southwestern Niger & Niger \\
\hline 293 & $\begin{array}{l}\text { Participatory investigation of Contagious Caprine Pleuropneumonia (CCPP) in goats in the Hammer } \\
\text { and Benna-Tsemay districts of southern Ethiopia }\end{array}$ & Ethiopia \\
\hline
\end{tabular}




\begin{tabular}{|c|c|c|}
\hline 297 & Lifestyle and herding practices of Bahima pastoralists in Uganda & Uganda \\
\hline 299 & $\begin{array}{l}\text { Participatory indicator development: what can ecologists and local communities learn from each } \\
\text { other? }\end{array}$ & Botswana \\
\hline 306 & $\begin{array}{l}\text { Framework for participatory assessments and implementation of global environmental conventions at } \\
\text { the community level }\end{array}$ & Tanzania \\
\hline 307 & Tūhoe Tuawhenua mātauranga of kererū (Hemiphaga novaseelandiae novaseelandiae) in Te Urewera & $\begin{array}{l}\text { New } \\
\text { Zealand }\end{array}$ \\
\hline 309 & $\begin{array}{l}\text { Changing communal land tenure in an East African pastoral system: Institutions and Socio- } \\
\text { Economic transformations among the Pokot of NW Kenya }\end{array}$ & Kenya \\
\hline 311 & $\begin{array}{l}\text { Environmental perceptions and practices of livestock keepers on the Namaqualand Commons } \\
\text { challenge conventional rangeland management }\end{array}$ & South Africa \\
\hline 313 & $\begin{array}{l}\text { Eliciting indigenous knowledge on tree fodder among Maasai pastoralists via a multi-method } \\
\text { sequencing approach }\end{array}$ & Kenya \\
\hline 316 & $\begin{array}{l}\text { Saami reindeer pastoralism under climate change: Applying a generalized framework for } \\
\text { vulnerability studies to a sub-arctic social-ecological system }\end{array}$ & Norway \\
\hline 317 & $\begin{array}{l}\text { Integrating local and scientific knowledge for adaptation to land degradation: Kalahari rangeland } \\
\text { management options }\end{array}$ & Botswana \\
\hline 319 & $\begin{array}{l}\text { Ecological implications of traditional livestock husbandry and associated land use practices: A case } \\
\text { study from the trans-Himalaya, India }\end{array}$ & India \\
\hline 320 & Changing grazing systems in central north Namibia & Namibia \\
\hline 321 & $\begin{array}{l}\text { Herders' Perceptions on Ruminant Livestock Breeds and Breeding Management in Southwestern } \\
\text { Niger }\end{array}$ & Niger \\
\hline 327 & $\begin{array}{l}\text { Genetic defects or generative prototypes? Competing models for livestock improvement in southern } \\
\text { Bolivia }\end{array}$ & Bolivia \\
\hline 328 & Herder knowledge of landscape assessments in arid rangelands in northern Tanzania & Tanzania \\
\hline 334 & $\begin{array}{l}\text { Indigenous knowledge and the desertification debate: problematising expert knowledge in North } \\
\text { Africa }\end{array}$ & Morocco \\
\hline 335 & $\begin{array}{l}\text { Carved trees in grazed forests in boreal Sweden-analysis of remaining trees, interpretation of past } \\
\text { land-use and implications for conservation }\end{array}$ & Sweden \\
\hline 336 & Effects of anthropogenic fire history on savanna vegetation in northeastern Namibia & Namibia \\
\hline 339 & $\begin{array}{l}\text { Influence of selective tree cutting, livestock and prescribed fire on herbaceous biomass in the } \\
\text { savannah woodlands of Burkina Faso, West Africa }\end{array}$ & $\begin{array}{l}\text { Burkina } \\
\text { Faso }\end{array}$ \\
\hline 342 & $\begin{array}{l}\text { The role of participatory problem analysis in performance improvement and sustainable management } \\
\text { of rainwater harvesting (RWH) systems: A case study of Makanya village,Tanzania }\end{array}$ & Tanzania \\
\hline 345 & $\begin{array}{l}\text { Community Based Interventions as a Strategy to Combat Desertification in the Arid and Semi-Arid } \\
\text { Rangelands of Kajiado District, Kenya }\end{array}$ & Kenya \\
\hline 346 & Natural remedies and nutraceuticals used in ethnoveterinary practices in inland southern Italy & Italy \\
\hline 347 & $\begin{array}{l}\text { Use of indigenous ecological knowledge of the Maasai pastoralists for assessing rangeland } \\
\text { biodiversity in Tanzania }\end{array}$ & Tanzania \\
\hline 348 & $\begin{array}{l}\text { Conflict Resolution by Participatory Management: Remote Sensing and GIS as Tools for } \\
\text { Communicating Land-use Needs for Reindeer Herding in Northern Sweden }\end{array}$ & Sweden \\
\hline 350 & $\begin{array}{l}\text { Beyond Ground Truth: GIS and the Environmental Knowledge of Herders, Professional Foresters, } \\
\text { and Other Traditional Communities }\end{array}$ & India \\
\hline 353 & $\begin{array}{l}\text { Current range condition in southern Ethiopia in relation to traditional management strategies: The } \\
\text { perceptions of Borana pastoralists }\end{array}$ & Ethiopia \\
\hline
\end{tabular}




\begin{tabular}{|l|l|l|}
\hline 357 & Tracking Pastoralist Migration: Lessons from the Ethiopian Somali National Regional State & Ethiopia \\
\hline 359 & $\begin{array}{l}\text { The use of herders' accounts to map livestock activities across agropastoral landscapes in Semi-Arid } \\
\text { Africa }\end{array}$ & Niger \\
\hline 360 & Participatory selection process for indicators of rangeland condition in the Kalahari & Botswana \\
\hline 362 & $\begin{array}{l}\text { Using indigenous knowledge in land use investigations: a participatory study in a semi-arid } \\
\text { mountainous region of Lebanon }\end{array}$ & Lebanon \\
& $\begin{array}{l}\text { Representations of Nature on the Mongolian Steppe: An Investigation of Scientific Knowledge } \\
\text { Construction }\end{array}$ & Mongolia \\
\hline 367 & $\begin{array}{l}\text { Environmental Change and Pastoral Perceptions: Degradation and Indigenous Knowledge in Two } \\
\text { African Pastoral Communities }\end{array}$ & $\begin{array}{l}\text { Kenya; } \\
\text { Namibia }\end{array}$ \\
\hline 371 & $\begin{array}{l}\text { Traditionallolowledge and practices of Bhotiya pastoralists of Kumaon Himalaya:the need for value } \\
\text { addition }\end{array}$ & India \\
\hline 376 & Sense or nonsense? Traditional methods of animal parasitic disease control & NA \\
\hline 379 & $\begin{array}{l}\text { Sustaining indigenous communities: Symbolic and instrumental dimensions of pastoral resource use } \\
\text { in Shimshal, northern Pakistan }\end{array}$ & Pakistan \\
\hline 380 & Incorporating indigenous knowledge of fodder trees into small-scale silvopastoral systems in Jamaica & Jamaica \\
\hline 381 & $\begin{array}{l}\text { Ethnoveterinary medicine in Afghanistan: an overview of indigenous animal health care among } \\
\text { Pashtun Koochi nomads }\end{array}$ & Afghanistan \\
\hline 383 & $\begin{array}{l}\text { Evaluating the effectiveness of participatory agroforestry extension programmes in a pastoral system, } \\
\text { based on existing traditional values }\end{array}$ & Kenya \\
\hline
\end{tabular}


Table A1.2. Data elicited from 152 fully reviewed papers (Title, affiliation, abstract, keywords, intro, M\&M, result and discussion, conclusion). Abbreviations:

Pastoral_type) 1: Nomad and semi-nomad, 2: Transhumant and semi-transhumant; 3: Sedentary; 4: Trabshumant and sedentary; 5: Nomad, Semi-nomad, Sedentary;

6: Nomad, Transhumant, Sedentary: 7: Not reported. TEK_Trans) if transition was mentioned 1; if transition was not mentioned: 0. Trans_Types) Erosion: 0; Hybrid:

1; Adaptation: 2; Retention: 3.

\begin{tabular}{|c|c|c|c|c|c|c|c|c|c|c|c|c|c|c|c|c|c|c|}
\hline 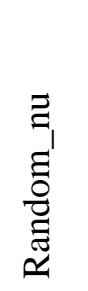 & $\stackrel{\vec{\nexists}}{\bar{\partial}}$ & 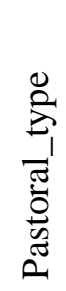 & 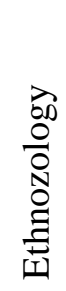 & 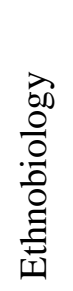 & 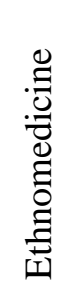 & 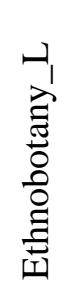 & 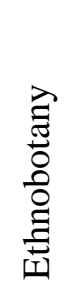 & 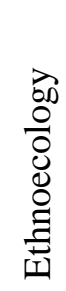 & 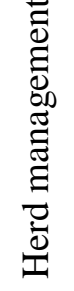 & 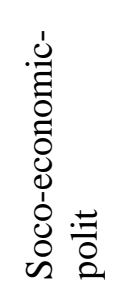 & 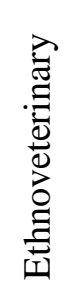 & 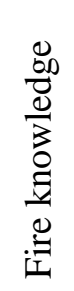 & 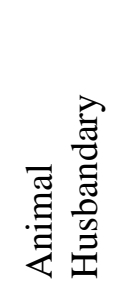 & 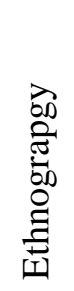 & 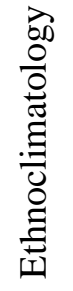 & 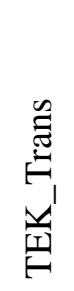 & 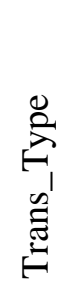 & 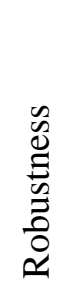 \\
\hline 115 & 2016 & 1 & 1 & 1 & 0 & 0 & 0 & 0 & 0 & 0 & 0 & 0 & 0 & 0 & 0 & 0 & NA & NA \\
\hline 140 & 2015 & 1 & 0 & 0 & 0 & 0 & 0 & 0 & 0 & 1 & 0 & 0 & 0 & 0 & 0 & 1 & 0 & 3 \\
\hline 136 & 2015 & 4 & 0 & 0 & 0 & 1 & 0 & 1 & 0 & 0 & 0 & 0 & 0 & 0 & 0 & 0 & $\mathrm{NA}$ & $\mathrm{NA}$ \\
\hline 92 & 2017 & 2 & 0 & 0 & 1 & 0 & 0 & 0 & 0 & 0 & 0 & 0 & 0 & 0 & 0 & 1 & 2 & 1 \\
\hline 141 & 2015 & 3 & 0 & 0 & 0 & 0 & 0 & 0 & 0 & 0 & 0 & 1 & 0 & 0 & 0 & 1 & 1 & 3 \\
\hline 150 & 2015 & 1 & 0 & 0 & 1 & 1 & 0 & 1 & 0 & 1 & 1 & 0 & 0 & 0 & 0 & 1 & 0 & 1 \\
\hline 220 & 2012 & 2 & 0 & 0 & 0 & 0 & 0 & 1 & 1 & 0 & 0 & 0 & 0 & 0 & 0 & 1 & 0 & 1 \\
\hline 105 & 2016 & 1 & 0 & 0 & 1 & 1 & 0 & 0 & 0 & 0 & 0 & 0 & 0 & 0 & 0 & 1 & 0 & 1 \\
\hline 159 & 2015 & 2 & 0 & 0 & 1 & 1 & 0 & 1 & 1 & 1 & 1 & 0 & 0 & 0 & 0 & 1 & 0 & 2 \\
\hline 31 & 2018 & 3 & 0 & 1 & 1 & 0 & 1 & 0 & 0 & 0 & 0 & 0 & 0 & 0 & 0 & 0 & NA & $\mathrm{NA}$ \\
\hline 101 & 2016 & 2 & 0 & 0 & 1 & 0 & 1 & 1 & 1 & 0 & 1 & 0 & 1 & 0 & 0 & 1 & 0 & 2 \\
\hline 233 & 2011 & 2 & 0 & 0 & 0 & 0 & 0 & 0 & 0 & 0 & 0 & 0 & 0 & 1 & 0 & 1 & 0 & 1 \\
\hline 58 & 2018 & 1 & 0 & 0 & 1 & 0 & 1 & 0 & 0 & 0 & 1 & 0 & 0 & 0 & 0 & 1 & 0 & 1 \\
\hline 366 & 2000 & 1 & 0 & 0 & 0 & 1 & 0 & 1 & 1 & 0 & 0 & 0 & 0 & 0 & 0 & 1 & 0 & 3 \\
\hline 315 & 2007 & 5 & 0 & 0 & 1 & 0 & 1 & 1 & 0 & 0 & 0 & 0 & 0 & 0 & 0 & 1 & 3 & 1 \\
\hline 282 & 2009 & 2 & 0 & 0 & 1 & 0 & 1 & 1 & 0 & 0 & 0 & 0 & 0 & 0 & 0 & 1 & 0 & 1 \\
\hline 261 & 2010 & 3 & 0 & 0 & 0 & 0 & 0 & 0 & 0 & 0 & 0 & 0 & 0 & 0 & 1 & 1 & 0 & 3 \\
\hline 212 & 2013 & 2 & 0 & 0 & 0 & 0 & 1 & 1 & 1 & 0 & 1 & 0 & 1 & 1 & 0 & 1 & 0 & 1 \\
\hline 184 & 2014 & 6 & 0 & 1 & 1 & 0 & 1 & 1 & 1 & 0 & 0 & 0 & 0 & 0 & 0 & 1 & 0 & 1 \\
\hline 182 & 2014 & 3 & 0 & 0 & 0 & 0 & 1 & 1 & 1 & 0 & 1 & 0 & 0 & 0 & 0 & 1 & 0 & 3 \\
\hline
\end{tabular}




\begin{tabular}{|c|c|c|c|c|c|c|c|c|c|c|c|c|c|c|c|c|c|c|}
\hline 169 & 2014 & 1 & 0 & 0 & 0 & 0 & 1 & 0 & 0 & 0 & 0 & 0 & 0 & 1 & 0 & 1 & 0 & 3 \\
\hline 281 & 2009 & 1 & 0 & 0 & 0 & 0 & 0 & 0 & 0 & 0 & 0 & 0 & 0 & 0 & 0 & 0 & NA & NA \\
\hline 133 & 2016 & 1 & 0 & 0 & 0 & 0 & 1 & 1 & 0 & 1 & 1 & 0 & 1 & 0 & 0 & 0 & NA & $\mathrm{NA}$ \\
\hline 283 & 2009 & 7 & 0 & 0 & 0 & 1 & 1 & 1 & 0 & 0 & 0 & 0 & 1 & 0 & 0 & 0 & NA & NA \\
\hline 227 & 2012 & 1 & 0 & 0 & 0 & 0 & 0 & 0 & 0 & 0 & 0 & 0 & 0 & 1 & 0 & 0 & NA & NA \\
\hline 183 & 2014 & 1 & 0 & 0 & 0 & 0 & 1 & 1 & 0 & 0 & 0 & 0 & 0 & 0 & 0 & 0 & NA & NA \\
\hline 303 & 2008 & 7 & 0 & 0 & 0 & 0 & 0 & 1 & 0 & 0 & 0 & 0 & 0 & 1 & 0 & 0 & NA & NA \\
\hline 310 & 2007 & 1 & 0 & 0 & 0 & 1 & 0 & 1 & 1 & 0 & 0 & 0 & 0 & 0 & 0 & 0 & NA & NA \\
\hline 11 & 2019 & 7 & 0 & 0 & 1 & 0 & 0 & 0 & 0 & 0 & 0 & 0 & 0 & 0 & 0 & 1 & 0 & 3 \\
\hline 235 & 2011 & 7 & 0 & 0 & 0 & 1 & 0 & 1 & 0 & 0 & 0 & 0 & 0 & 0 & 0 & 0 & NA & NA \\
\hline 228 & 2012 & 7 & 0 & 0 & 0 & 0 & 0 & 1 & 0 & 0 & 0 & 1 & 0 & 0 & 0 & 0 & NA & NA \\
\hline & 2000 & 1 & 0 & 0 & 0 & 0 & 0 & 1 & 0 & 0 & 0 & 0 & 0 & 1 & 0 & 0 & NA & NA \\
\hline 62 & 2018 & 3 & 0 & 0 & 0 & 1 & 0 & 1 & 1 & 0 & 0 & 0 & 0 & 0 & 0 & 0 & NA & NA \\
\hline 148 & 2015 & 1 & 0 & 0 & 1 & 0 & 0 & 0 & 0 & 0 & 0 & 0 & 0 & 0 & 0 & 1 & 0 & 1 \\
\hline 294 & 2008 & 7 & 0 & 0 & 0 & 1 & 0 & 0 & 0 & 0 & 0 & 0 & 0 & 0 & 0 & 0 & NA & NA \\
\hline 165 & 2015 & 1 & 0 & 0 & 0 & 0 & 0 & 0 & 1 & 1 & 0 & 0 & 1 & 0 & 0 & 0 & NA & NA \\
\hline 259 & 2010 & 1 & 0 & 0 & 0 & 0 & 0 & 1 & 0 & 0 & 0 & 0 & 0 & 0 & 0 & 0 & NA & NA \\
\hline 4 & 2019 & 7 & 0 & 0 & 0 & 0 & 0 & 1 & 0 & 0 & 0 & 0 & 0 & 0 & 1 & 1 & 0 & 3 \\
\hline 292 & 2008 & 7 & 0 & 0 & 0 & 0 & 0 & 0 & 0 & 0 & 0 & 0 & 1 & 1 & 0 & 1 & 0 & 2 \\
\hline 363 & 2001 & 3 & 0 & 0 & 0 & 1 & 0 & 1 & 1 & 0 & 0 & 0 & 0 & 0 & 0 & 0 & NA & NA \\
\hline 289 & 2009 & 7 & 0 & 0 & 0 & 0 & 0 & 0 & 0 & 0 & 0 & 0 & 0 & 0 & 0 & 1 & 0 & 3 \\
\hline 175 & 2014 & 7 & 0 & 0 & 0 & 0 & 0 & 1 & 0 & 0 & 0 & 0 & 0 & 0 & 1 & 0 & NA & $\mathrm{NA}$ \\
\hline 36 & 2018 & 3 & 0 & 0 & 0 & 0 & 0 & 0 & 1 & 0 & 0 & 0 & 1 & 0 & 0 & 1 & 0 & 3 \\
\hline 180 & 2014 & 7 & 1 & 1 & 0 & 0 & 0 & 0 & 0 & 0 & 0 & 0 & 0 & 0 & 0 & 0 & NA & NA \\
\hline 325 & 2006 & 7 & 0 & 0 & 0 & 0 & 0 & 0 & 1 & 0 & 0 & 0 & 0 & 0 & 0 & 0 & NA & NA \\
\hline 286 & 2009 & 1 & 0 & 0 & 0 & 1 & 0 & 1 & 1 & 0 & 0 & 0 & 0 & 0 & 0 & 0 & NA & NA \\
\hline 48 & 2018 & 7 & 0 & 0 & 0 & 0 & 0 & 1 & 0 & 0 & 0 & 0 & 0 & 0 & 1 & 0 & NA & $\mathrm{NA}$ \\
\hline 181 & 2014 & 2 & 0 & 0 & 0 & 0 & 0 & 0 & 0 & 0 & 0 & 0 & 0 & 0 & 1 & 0 & NA & NA \\
\hline 28 & 2018 & 2 & 0 & 0 & 0 & 0 & 0 & 1 & 0 & 0 & 0 & 0 & 0 & 0 & 1 & 0 & NA & NA \\
\hline 333 & 2006 & 3 & 0 & 0 & 1 & 0 & 0 & 0 & 0 & 0 & 0 & 0 & 0 & 0 & 0 & 1 & 0 & 2 \\
\hline
\end{tabular}




\begin{tabular}{|c|c|c|c|c|c|c|c|c|c|c|c|c|c|c|c|c|c|c|}
\hline 176 & 2014 & 1 & 0 & 0 & 1 & 0 & 0 & 0 & 0 & 0 & 0 & 0 & 0 & 0 & 0 & 1 & 0 & 2 \\
\hline 129 & 2016 & 7 & 0 & 0 & 0 & 0 & 0 & 1 & 0 & 0 & 0 & 0 & 0 & 0 & 0 & 0 & NA & NA \\
\hline 278 & 2009 & 4 & 0 & 0 & 0 & 0 & 0 & 1 & 0 & 0 & 0 & 0 & 0 & 0 & 0 & 1 & 0 & 1 \\
\hline 19 & 2019 & 7 & 0 & 0 & 0 & 0 & 0 & 1 & 0 & 0 & 0 & 0 & 0 & 0 & 1 & 1 & 0 & 3 \\
\hline 301 & 2008 & 3 & 0 & 0 & 0 & 1 & 0 & 1 & 0 & 0 & 0 & 0 & 0 & 0 & 0 & 0 & NA & $\mathrm{NA}$ \\
\hline 214 & 2012 & 2 & 0 & 0 & 1 & 0 & 0 & 0 & 0 & 0 & 0 & 0 & 0 & 0 & 0 & 1 & 0 & 1 \\
\hline 73 & 2017 & 6 & 0 & 0 & 0 & 0 & 0 & 1 & 0 & 1 & 0 & 0 & 0 & 0 & 0 & 1 & 1 & 3 \\
\hline 229 & 2012 & 1 & 0 & 0 & 0 & 0 & 0 & 0 & 0 & 0 & 0 & 0 & 0 & 1 & 0 & 1 & 2 & 1 \\
\hline 263 & 2010 & 1 & 0 & 0 & 0 & 0 & 0 & 1 & 0 & 0 & 0 & 0 & 0 & 0 & 1 & 0 & NA & NA \\
\hline 164 & 2015 & 1 & 0 & 0 & 0 & 0 & 0 & 0 & 0 & 0 & 0 & 0 & 0 & 1 & 0 & 0 & NA & NA \\
\hline 53 & 2018 & 1 & 0 & 0 & 0 & 0 & 0 & 0 & 1 & 1 & 0 & 0 & 0 & 0 & 0 & 1 & 0 & 2 \\
\hline 280 & 2009 & 7 & 1 & 1 & 0 & 0 & 0 & 0 & 0 & 0 & 0 & 0 & 0 & 0 & 0 & 0 & NA & $\mathrm{NA}$ \\
\hline 80 & 2017 & 7 & 0 & 0 & 0 & 0 & 0 & 0 & 0 & 0 & 0 & 0 & 0 & 0 & 1 & 0 & NA & NA \\
\hline 252 & 2011 & 7 & 0 & 0 & 0 & 0 & 0 & 0 & 0 & 1 & 0 & 0 & 0 & 0 & 0 & 0 & NA & NA \\
\hline 35 & 2018 & 2 & 0 & 0 & 0 & 0 & 0 & 0 & 0 & 1 & 0 & 0 & 0 & 0 & 0 & 1 & 0 & 3 \\
\hline 91 & 2017 & 2 & 0 & 0 & 0 & 0 & 0 & 0 & 0 & 0 & 1 & 0 & 1 & 0 & 0 & 0 & NA & NA \\
\hline 226 & 2012 & 7 & 0 & 0 & 0 & 1 & 1 & 1 & 0 & 0 & 0 & 0 & 0 & 0 & 0 & 0 & NA & $\mathrm{NA}$ \\
\hline 67 & 2017 & 1 & 0 & 0 & 0 & 0 & 0 & 0 & 0 & 0 & 0 & 0 & 0 & 1 & 0 & 1 & 1 & 3 \\
\hline 260 & 2009 & 7 & 0 & 0 & 0 & 0 & 1 & 1 & 0 & 0 & 0 & 0 & 0 & 0 & 0 & 0 & NA & NA \\
\hline 143 & 2015 & 7 & 0 & 0 & 0 & 0 & 0 & 0 & 0 & 1 & 0 & 0 & 0 & 0 & 0 & 0 & NA & NA \\
\hline 111 & 2016 & 7 & 0 & 0 & 0 & 0 & 0 & 0 & 0 & 1 & 0 & 0 & 0 & 0 & 0 & 1 & 0 & 3 \\
\hline 323 & 2007 & 7 & 0 & 0 & 0 & 1 & 0 & 0 & 1 & 0 & 0 & 0 & 1 & 0 & 0 & 0 & NA & NA \\
\hline 94 & 2017 & 2 & 0 & 0 & 0 & 0 & 0 & 0 & 1 & 1 & 0 & 0 & 0 & 0 & 0 & 1 & 0 & 3 \\
\hline 331 & 2006 & 7 & 0 & 0 & 0 & 0 & 0 & 0 & 0 & 0 & 1 & 0 & 0 & 0 & 0 & 0 & NA & NA \\
\hline 119 & 2016 & 7 & 0 & 0 & 0 & 0 & 0 & 0 & 0 & 0 & 0 & 0 & 0 & 0 & 1 & 0 & NA & NA \\
\hline 318 & 2007 & 7 & 1 & 0 & 0 & 0 & 0 & 0 & 0 & 0 & 0 & 0 & 0 & 1 & 0 & 1 & 0 & 3 \\
\hline 132 & 2016 & 7 & 0 & 0 & 0 & 0 & 1 & 1 & 0 & 0 & 0 & 0 & 0 & 0 & 0 & 0 & NA & $\mathrm{NA}$ \\
\hline 102 & 2016 & 5 & 0 & 0 & 0 & 0 & 1 & 1 & 0 & 0 & 0 & 0 & 0 & 0 & 0 & 0 & NA & NA \\
\hline 322 & 2007 & 2 & 0 & 0 & 0 & 0 & 0 & 0 & 0 & 1 & 0 & 0 & 0 & 0 & 0 & 0 & NA & NA \\
\hline 199 & 2013 & 1 & 0 & 0 & 1 & 0 & 0 & 0 & 0 & 0 & 0 & 0 & 0 & 0 & 0 & 1 & 0 & 3 \\
\hline
\end{tabular}




\begin{tabular}{|c|c|c|c|c|c|c|c|c|c|c|c|c|c|c|c|c|c|c|}
\hline 240 & 2011 & 7 & 0 & \begin{tabular}{|l|l}
0 \\
\end{tabular} & \begin{tabular}{|l|l|}
0 \\
\end{tabular} & 0 & 0 & \begin{tabular}{|l|}
1 \\
\end{tabular} & 0 & 0 & \begin{tabular}{|l|l}
0 \\
\end{tabular} & \begin{tabular}{|l|l|}
0 \\
\end{tabular} & \begin{tabular}{|l|l}
0 \\
\end{tabular} & 0 & 0 & \begin{tabular}{|l|l} 
\\
\end{tabular} & \begin{tabular}{|l|l} 
NA \\
\end{tabular} & NA \\
\hline 87 & 2017 & 7 & 1 & 1 & 0 & 0 & 0 & 0 & 0 & 0 & 0 & 0 & 0 & \begin{tabular}{|l|l|} 
\\
\end{tabular} & 0 & 0 & NA & NA \\
\hline 268 & 2010 & 7 & 0 & 0 & 0 & 0 & 0 & 0 & \begin{tabular}{|l|l|} 
\\
\end{tabular} & 1 & 0 & 0 & 0 & \begin{tabular}{|l|l|} 
\\
\end{tabular} & 0 & 0 & NA & NA \\
\hline 97 & 2017 & 7 & 0 & 0 & 0 & 0 & 0 & 0 & 0 & 1 & 0 & 0 & 0 & $\mid \begin{array}{l}\mid 0 \\
\end{array}$ & 0 & 0 & NA & NA \\
\hline 272 & 2009 & 5 & 0 & 0 & 0 & 0 & 0 & 0 & 0 & 1 & 0 & 0 & 0 & 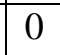 & 0 & 1 & 0 & 1 \\
\hline 107 & 2016 & 7 & 0 & 0 & 0 & 0 & 0 & 0 & \begin{tabular}{|l|l|}
0 \\
\end{tabular} & 1 & 0 & 0 & 0 & \begin{tabular}{|l|l|} 
\\
\end{tabular} & 0 & 0 & NA & NA \\
\hline 130 & 2016 & 1 & 0 & 0 & 0 & 0 & 0 & 1 & \begin{tabular}{|l|l|}
0 \\
\end{tabular} & 0 & 0 & 0 & 1 & 1 & 1 & 1 & 0 & 1 \\
\hline 147 & 2015 & 1 & 0 & 1 & \begin{tabular}{|l|l} 
\\
\end{tabular} & 0 & 0 & 0 & \begin{tabular}{|l|}
0 \\
\end{tabular} & 0 & 1 & 0 & 0 & 0 & 0 & 1 & 0 & \begin{tabular}{|l|} 
\\
\end{tabular} \\
\hline 25 & 2019 & 7 & 0 & 0 & \begin{tabular}{|l|l} 
\\
\end{tabular} & 0 & 0 & 1 & \begin{tabular}{|l|}
0 \\
\end{tabular} & 0 & 0 & \begin{tabular}{|l|}
1 \\
\end{tabular} & 0 & 0 & 0 & 0 & NA & NA \\
\hline 114 & 2016 & 3 & 0 & 0 & \begin{tabular}{|l|l} 
\\
\end{tabular} & 1 & 0 & 0 & \begin{tabular}{|l|}
0 \\
\end{tabular} & 0 & 1 & 0 & 1 & \begin{tabular}{|l|l|}
0 \\
\end{tabular} & 0 & 0 & NA & NA \\
\hline 284 & 2009 & 7 & 0 & 0 & \begin{tabular}{|l|l} 
\\
\end{tabular} & 0 & 0 & 0 & \begin{tabular}{|l|}
0 \\
\end{tabular} & 1 & 0 & 0 & 0 & 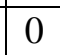 & 0 & 0 & NA & NA \\
\hline 300 & 2008 & 3 & 0 & 0 & \begin{tabular}{|l|l} 
\\
\end{tabular} & 0 & 0 & 0 & \begin{tabular}{|l|}
1 \\
\end{tabular} & 1 & 0 & \begin{tabular}{|l|l} 
\\
\end{tabular} & 0 & 0 & 0 & 1 & 0 & 2 \\
\hline 85 & 2017 & 7 & 0 & 0 & \begin{tabular}{|l|}
1 \\
\end{tabular} & 1 & 1 & 1 & \begin{tabular}{|l|} 
\\
\end{tabular} & 0 & 0 & \begin{tabular}{|l|l} 
\\
\end{tabular} & 0 & 0 & 0 & 1 & 0 & 3 \\
\hline 65 & 2018 & 7 & 0 & 0 & \begin{tabular}{|l|l} 
\\
\end{tabular} & 0 & 0 & \begin{tabular}{|l|l} 
\\
\end{tabular} & \begin{tabular}{|l|l|} 
\\
\end{tabular} & 0 & 1 & 0 & \begin{tabular}{|l|l} 
\\
\end{tabular} & 0 & 0 & 0 & NA & NA \\
\hline 234 & 2011 & 7 & 0 & 0 & 0 & 0 & 0 & 1 & \begin{tabular}{|l|l|}
0 \\
\end{tabular} & 0 & 0 & 0 & 0 & 0 & 0 & 1 & 0 & 3 \\
\hline 262 & 2010 & 7 & 0 & 0 & 0 & 0 & 0 & 0 & \begin{tabular}{|l|l|} 
\\
\end{tabular} & 1 & 0 & 0 & 0 & 0 & 0 & 1 & 0 & 3 \\
\hline 210 & 2013 & 7 & 0 & 0 & 0 & 0 & 0 & 0 & \begin{tabular}{|l|}
0 \\
\end{tabular} & 0 & 1 & 0 & 0 & \begin{tabular}{|l|l}
0 \\
\end{tabular} & 0 & 0 & NA & NA \\
\hline 330 & 2006 & 7 & 0 & 0 & 0 & 1 & 0 & 1 & \begin{tabular}{|l|}
0 \\
\end{tabular} & 0 & 0 & 0 & 0 & \begin{tabular}{|l|l}
0 \\
\end{tabular} & 0 & 1 & 0 & 1 \\
\hline 238 & 2011 & 1 & 0 & 0 & 0 & 0 & 0 & 0 & \begin{tabular}{|l|l|} 
\\
\end{tabular} & 0 & 0 & 0 & 1 & \begin{tabular}{|l|l|}
0 \\
\end{tabular} & 0 & 0 & NA & NA \\
\hline 86 & 2017 & 1 & 0 & 0 & 1 & 1 & 0 & \begin{tabular}{|l|}
1 \\
\end{tabular} & \begin{tabular}{|l|}
0 \\
\end{tabular} & 0 & 0 & 0 & 1 & \begin{tabular}{|l|l|}
0 \\
\end{tabular} & 0 & 1 & 0 & 3 \\
\hline 201 & 2013 & 7 & 0 & 0 & 0 & 0 & 0 & 0 & \begin{tabular}{|l|}
0 \\
\end{tabular} & 1 & 0 & 0 & 0 & \begin{tabular}{|l|l}
0 \\
\end{tabular} & 0 & 0 & NA & NA \\
\hline 47 & 2018 & 7 & 0 & 0 & 0 & 0 & 0 & 0 & \begin{tabular}{|l|l|}
0 \\
\end{tabular} & 0 & 0 & 0 & 0 & 1 & 0 & 1 & 0 & 3 \\
\hline 90 & 2017 & 2 & 0 & 0 & 1 & 0 & 0 & 1 & 0 & 1 & 0 & 0 & 0 & 0 & 0 & 0 & NA & NA \\
\hline $\begin{array}{ll}178 \\
\end{array}$ & 2014 & 7 & 0 & 0 & 0 & 0 & 0 & 1 & \begin{tabular}{|l|l|}
1 \\
\end{tabular} & 0 & 0 & 0 & 0 & 0 & 0 & 0 & NA & NA \\
\hline 209 & 2013 & 7 & 0 & 0 & 0 & 0 & 0 & 0 & \begin{tabular}{|l|}
1 \\
\end{tabular} & 1 & 0 & 0 & 0 & 0 & 0 & 0 & NA & NA \\
\hline 204 & 2013 & 1 & 0 & 0 & 0 & 0 & 0 & 0 & \begin{tabular}{|l|l|} 
\\
\end{tabular} & 0 & 1 & 0 & 0 & 0 & 0 & 0 & NA & NA \\
\hline 223 & 2011 & 7 & 0 & 0 & 0 & 0 & 0 & 0 & 0 & 0 & 0 & 0 & 1 & 0 & 0 & 0 & NA & NA \\
\hline 45 & 2018 & 2 & 0 & 0 & 0 & 0 & 0 & 0 & \begin{tabular}{|l|l|}
1 \\
\end{tabular} & 1 & 0 & 1 & 0 & 1 & 0 & 1 & 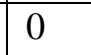 & 3 \\
\hline 9 & 2018 & 5 & 0 & 0 & 0 & 0 & 0 & 0 & 0 & 0 & 0 & 0 & 0 & 0 & 1 & 0 & NA & NA \\
\hline 302 & 2008 & 7 & 0 & 0 & 0 & 1 & 1 & 0 & \begin{tabular}{|l|l|}
1 \\
\end{tabular} & 0 & 0 & 0 & 0 & 0 & 0 & 0 & NA & NA \\
\hline
\end{tabular}




\begin{tabular}{|c|c|c|c|c|c|c|c|c|c|c|c|c|c|c|c|c|c|c|}
\hline 146 & 2015 & 1 & 0 & 0 & 0 & 0 & 0 & 0 & 0 & 0 & 1 & 0 & 0 & 0 & 0 & 0 & NA & NA \\
\hline 3 & 2019 & 5 & 0 & 0 & 0 & 0 & 0 & 0 & 0 & 0 & 0 & 0 & 1 & 0 & 0 & 1 & 0 & 3 \\
\hline 277 & 2009 & 1 & 0 & 0 & 0 & 0 & 0 & 1 & 0 & 0 & 0 & 0 & 0 & 0 & 0 & 0 & NA & $\mathrm{NA}$ \\
\hline 256 & 2010 & 7 & 0 & 0 & 1 & 0 & 0 & 0 & 0 & 0 & 0 & 0 & 0 & 0 & 0 & 0 & NA & NA \\
\hline 314 & 2007 & & 0 & 0 & 0 & 1 & 0 & 1 & 0 & 1 & 0 & 0 & 0 & 0 & 0 & 0 & NA & NA \\
\hline 258 & 2010 & 1 & 0 & 0 & 0 & 0 & 0 & 0 & 0 & 0 & 1 & 0 & 0 & 0 & 0 & 1 & 0 & 3 \\
\hline 41 & 2018 & 7 & 0 & 0 & 0 & 0 & 0 & 0 & 0 & 0 & 0 & 0 & 0 & 0 & 1 & 0 & NA & NA \\
\hline 32 & 2018 & 1 & 0 & 0 & 1 & 0 & 0 & 0 & 0 & 1 & 1 & 0 & 1 & 0 & 0 & 0 & NA & NA \\
\hline 34 & 2018 & 7 & 0 & 0 & 0 & 1 & 0 & 1 & 0 & 0 & 0 & 0 & 0 & 0 & 0 & 0 & NA & NA \\
\hline 81 & 2017 & 7 & 1 & 0 & 0 & 0 & 0 & 0 & 0 & 0 & 0 & 0 & 0 & 0 & 0 & 0 & NA & NA \\
\hline 177 & 2014 & 7 & 0 & 0 & 0 & 0 & 0 & 0 & 0 & 1 & 0 & 0 & 1 & 0 & 0 & 0 & NA & NA \\
\hline 43 & 2018 & 7 & 0 & 0 & 1 & 0 & 0 & 0 & 0 & 0 & 0 & 0 & 0 & 0 & 0 & 0 & NA & NA \\
\hline 338 & 2005 & 7 & 0 & 0 & 1 & 1 & 0 & 0 & 0 & 1 & 0 & 0 & 0 & 0 & 0 & 0 & NA & NA \\
\hline 104 & 2016 & 7 & 0 & 0 & 0 & 0 & 0 & 0 & 1 & 1 & 0 & 0 & 0 & 0 & 0 & 1 & 0 & 3 \\
\hline 161 & 2015 & 2 & 0 & 0 & 0 & 0 & 0 & 0 & 1 & 1 & 0 & 0 & 0 & 0 & 1 & 0 & NA & NA \\
\hline 222 & 2012 & 7 & 0 & 0 & 0 & 0 & 0 & 0 & 0 & 1 & 0 & 0 & 1 & 0 & 0 & 0 & NA & NA \\
\hline 63 & 2018 & 2 & 0 & 0 & 0 & 1 & 0 & 1 & 0 & 0 & 0 & 0 & 0 & 0 & 0 & 1 & 0 & 1 \\
\hline 15 & 2019 & 1 & 0 & 0 & 1 & 0 & 0 & 0 & 0 & 0 & 0 & 0 & 0 & 0 & 0 & 0 & NA & $\mathrm{NA}$ \\
\hline 44 & 2018 & 7 & 0 & 0 & 0 & 0 & 0 & 0 & 0 & 0 & 1 & 0 & 0 & 0 & 0 & 1 & 0 & 2 \\
\hline 296 & 2008 & 3 & 0 & 0 & 0 & 0 & 0 & 0 & 1 & 0 & 0 & 0 & 0 & 0 & 0 & 0 & NA & NA \\
\hline 123 & 2015 & 2 & 0 & 0 & 0 & 0 & 0 & 0 & 1 & 1 & 0 & 0 & 0 & 0 & 0 & 0 & NA & $\mathrm{NA}$ \\
\hline 71 & 2017 & 1 & 0 & 0 & 1 & 0 & 1 & 1 & 0 & 1 & 0 & 0 & 0 & 0 & 0 & 1 & 2 & 1 \\
\hline 361 & 2002 & 7 & 0 & 0 & 0 & 0 & 0 & 0 & 0 & 1 & 0 & 0 & 1 & 0 & 0 & 0 & NA & NA \\
\hline 162 & 2015 & 2 & 0 & 0 & 0 & 1 & 0 & 0 & 0 & 1 & 0 & 0 & 0 & 0 & 0 & 1 & 0 & 3 \\
\hline 349 & 2003 & 1 & 0 & 0 & 0 & 0 & 0 & 1 & 0 & 0 & 0 & 0 & 0 & 0 & 0 & 0 & NA & NA \\
\hline 78 & 2017 & 7 & 1 & 0 & 0 & 0 & 0 & 0 & 0 & 0 & 0 & 0 & 0 & 0 & 0 & 0 & NA & NA \\
\hline 358 & 2002 & 7 & 1 & 0 & 0 & 0 & 0 & 0 & 0 & 0 & 0 & 0 & 0 & 1 & 0 & 1 & 0 & 2 \\
\hline 179 & 2014 & 1 & 0 & 0 & 0 & 0 & 0 & 0 & 0 & 0 & 0 & 0 & 0 & 0 & 0 & 1 & 0 & 3 \\
\hline 75 & 2017 & 2 & 0 & 0 & 0 & 0 & 0 & 0 & 0 & 1 & 0 & 0 & 0 & 0 & 0 & 0 & NA & NA \\
\hline 22 & 2019 & 1 & 0 & 0 & 1 & 0 & 0 & 0 & 0 & 0 & 0 & 0 & 0 & 0 & 0 & 1 & 3 & 1 \\
\hline
\end{tabular}




\begin{tabular}{|l|l|l|l|l|l|l|l|l|l|l|l|l|l|l|l|l|l|l|}
\hline 231 & 2012 & 7 & 1 & 0 & 0 & 0 & 0 & 0 & 0 & 0 & 0 & 0 & 0 & 0 & 0 & 0 & NA & NA \\
\hline 196 & 2013 & 1 & 0 & 0 & 0 & 1 & 0 & 0 & 0 & 0 & 0 & 0 & 0 & 0 & 0 & 0 & NA & NA \\
\hline 326 & 2006 & 5 & 0 & 0 & 0 & 0 & 0 & 0 & 0 & 1 & 0 & 0 & 1 & 0 & 0 & 0 & NA & NA \\
\hline 218 & 2012 & 2 & 0 & 0 & 1 & 0 & 0 & 0 & 0 & 0 & 0 & 0 & 0 & 0 & 0 & 1 & 0 & 2 \\
\hline 88 & 2017 & 7 & 0 & 0 & 0 & 1 & 0 & 0 & 0 & 0 & 0 & 0 & 0 & 0 & 0 & 1 & 3 & 1 \\
\hline 72 & 2017 & 2 & 1 & 0 & 0 & 0 & 0 & 0 & 0 & 1 & 0 & 0 & 0 & 0 & 0 & 1 & 2 & 1 \\
\hline 125 & 2016 & 7 & 0 & 0 & 0 & 0 & 0 & 0 & 1 & 1 & 0 & 0 & 0 & 0 & 1 & 1 & 0 & 2 \\
\hline 186 & 2014 & 1 & 0 & 0 & 0 & 0 & 0 & 0 & 0 & 1 & 0 & 0 & 0 & 1 & 0 & 0 & NA & NA \\
\hline 70 & 2017 & 2 & 0 & 0 & 0 & 1 & 1 & 1 & 0 & 0 & 0 & 0 & 0 & 0 & 0 & 0 & NA & NA \\
\hline 378 & 1996 & 1 & 0 & 0 & 0 & 0 & 0 & 0 & 0 & 1 & 1 & 0 & 0 & 0 & 0 & 0 & NA & NA \\
\hline 352 & 2003 & 1 & 0 & 0 & 0 & 0 & 0 & 0 & 1 & 1 & 0 & 0 & 1 & 0 & 0 & 0 & NA & NA \\
\hline 298 & 2008 & 3 & 0 & 0 & 0 & 0 & 0 & 0 & 1 & 1 & 0 & 0 & 0 & 0 & 0 & 0 & NA & NA \\
\hline
\end{tabular}


Comparing initial (102 papers) and total (152 papers) datasets to find out if the number of the subsamples should increase or not. Wilcoxon test was used to compare two groups regarding TEK transition variable as following:

Table A1.3. Mean ranks and comparison between initial and final dataset

\begin{tabular}{|l|l|l|l|}
\hline Dataset & $\mathrm{N}$ & Mean Rank & Sig \\
\hline Initial dataset & 102 & 131.76 & \multirow{2}{*}{0.378} \\
\hline Total dataset & 152 & 124.64 & \\
\hline
\end{tabular}

CodeA1.1. Script code in $\mathrm{R}$

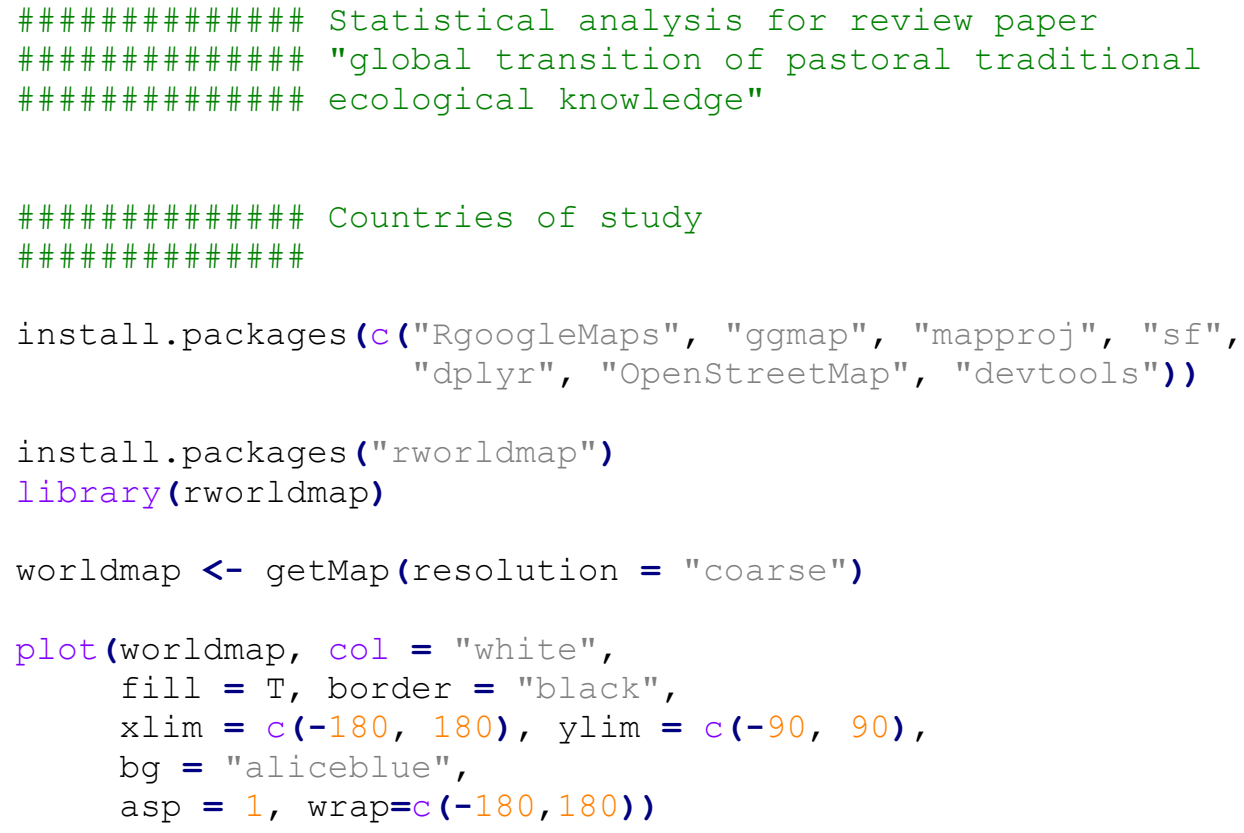




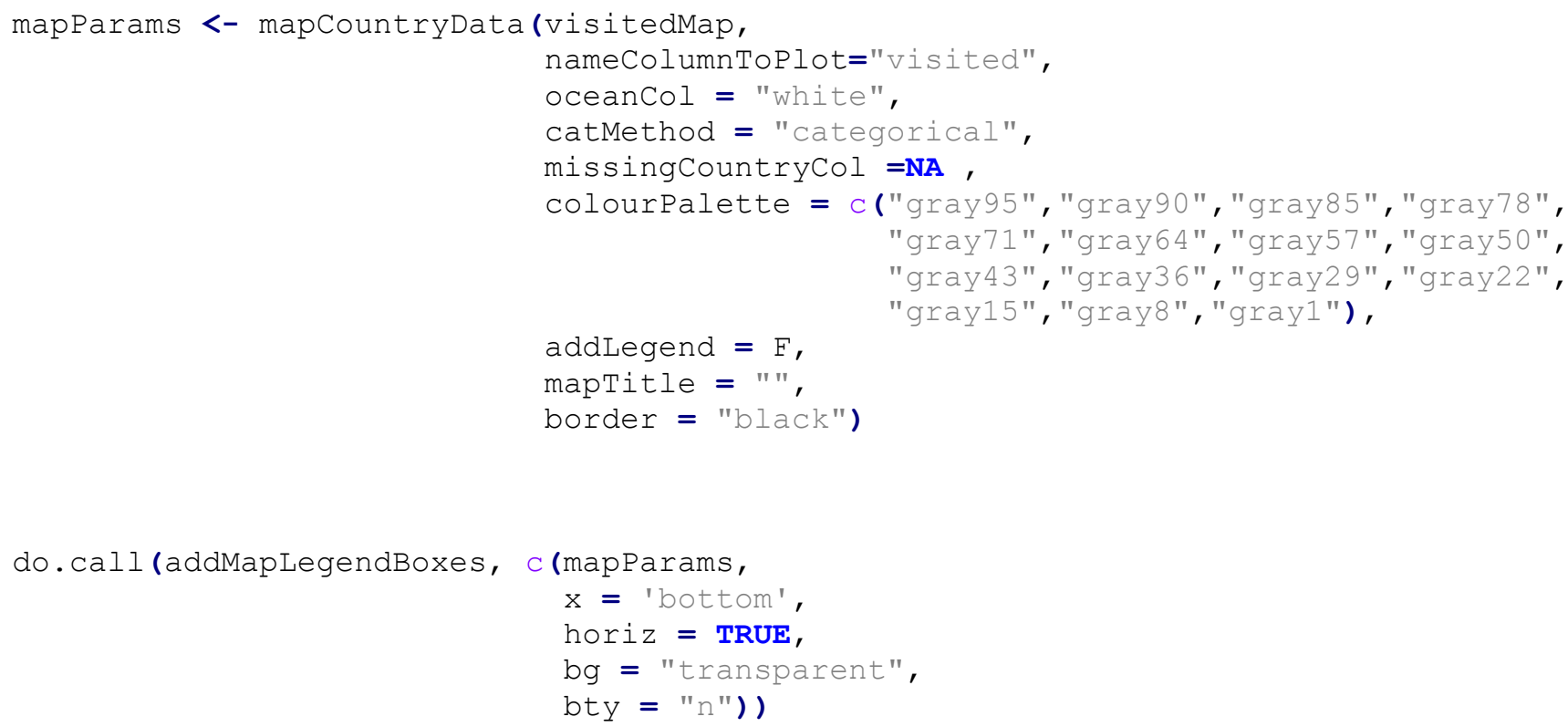




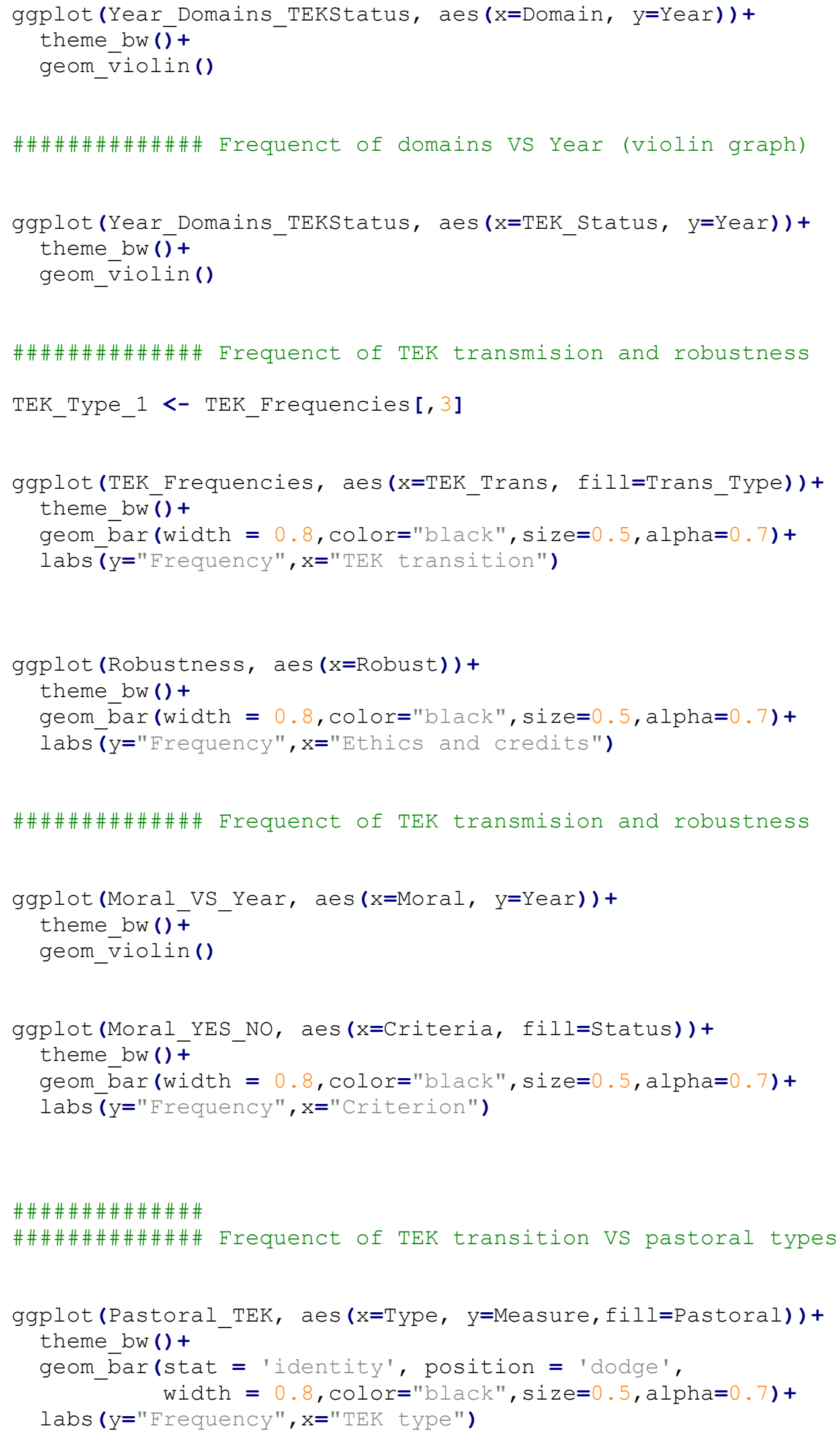




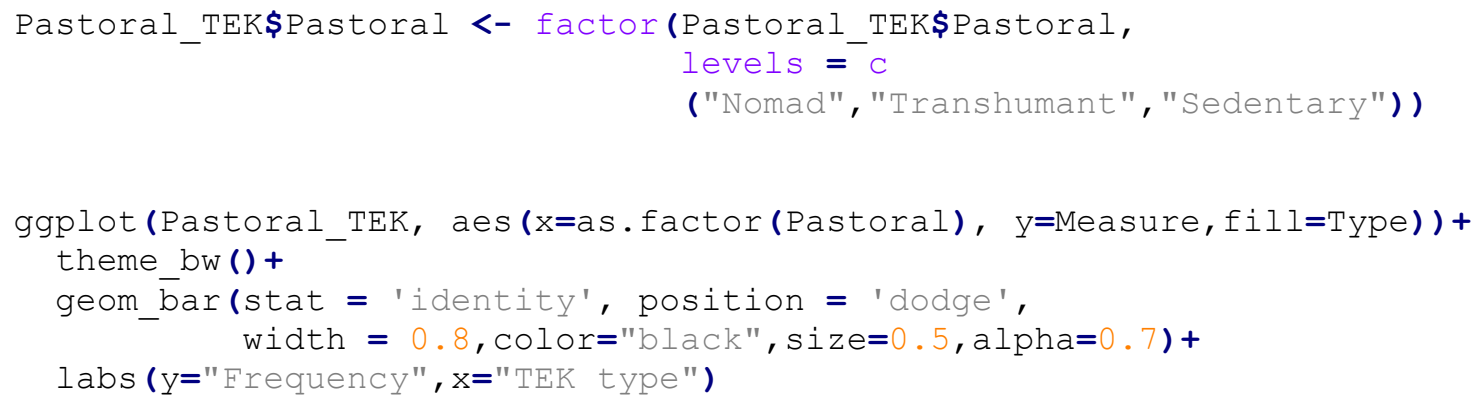




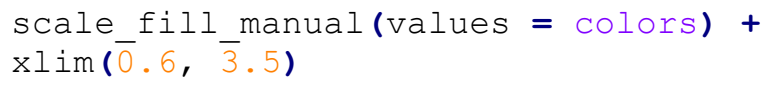

donut

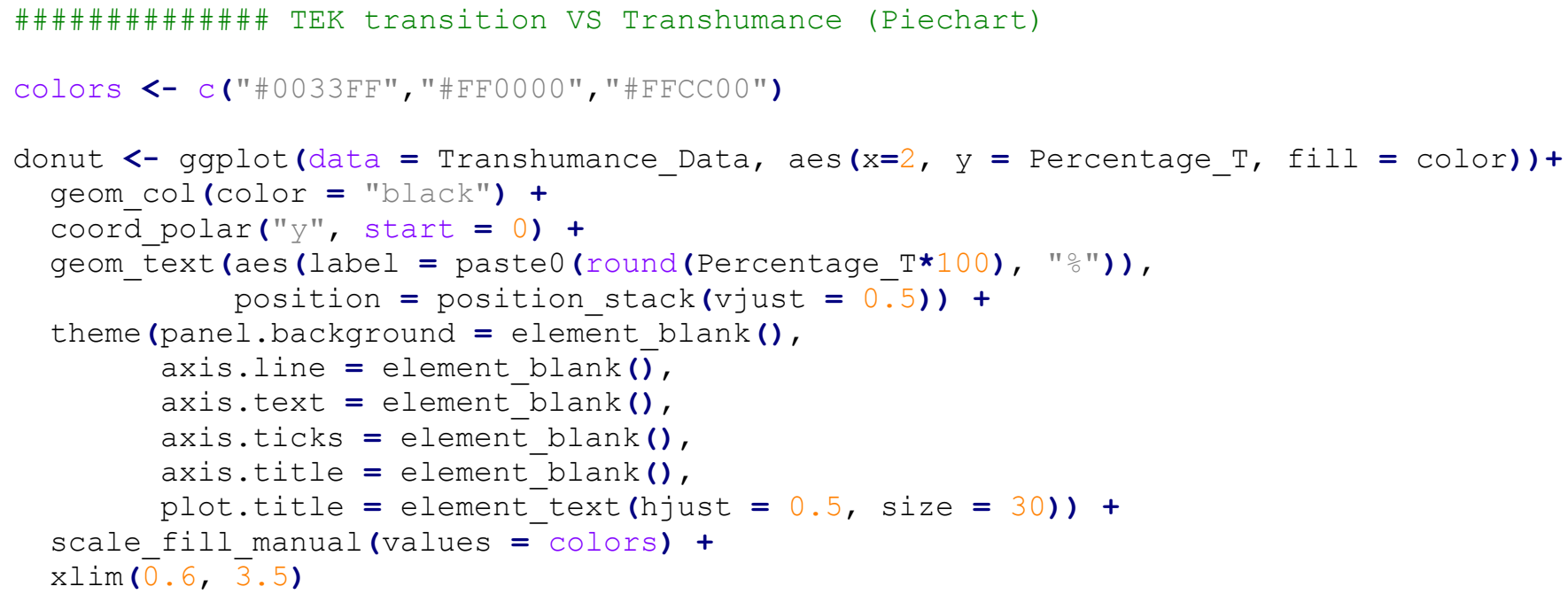

donut

\#\#\#\#\#\#\#\#\#\#\#\# TEK transition VS Sedentary (Piechart)

colors <- c("\#33FFOO", "\#FFO000", "\#FFCCOO")

donut <- ggplot(data = Sedentary_Data, aes (x=2, y = Percentage_S, fill = color))+ geom_col (color $=$ "black") +

donut 
Abate, T., Ebro, A. and Nigatu, L., 2010. Traditional rangeland resource utilisation practices and pastoralists' perceptions on land degradation in south-east Ethiopia. Tropical grasslands, 44(3), pp.202-212.

Abbasi, A.M., Khan, S.M., Ahmad, M., Khan, M.A., Quave, C.L. and Pieroni, A., 2013. Botanical ethnoveterinary therapies in three districts of the Lesser Himalayas of Pakistan. Journal of ethnobiology and ethnomedicine, 9(1), pp.1-21.

Abbet, C., Slacanin, I., Corradi, E., De Mieri, M., Hamburger, M. and Potterat, O., 2014. Comprehensive analysis of Cirsium spinosissimum Scop., a wild alpine food plant. Food chemistry, 160, pp.165-170.

Abdelhadi, O.M.A., Babiker, S.A., El-Emam, M.B. and Faye, B., 2011. Husbandry practices of EL-Kababish camel herders: Case study north Kordofan state, Sudan. Journal of Camel Practice and Research, 18(1), pp.7-14.

Abdussamad, A.M., Charruau, P., Kalla, D.J.U. and Burger, P.A., 2015. Validating local knowledge on camels: colour phenotypes and genetic variation of dromedaries in the Nigeria-Niger corridor. Livestock Science, 181, pp.131-136.

Addison, J. and Pavey, C.R., 2017. Alignment between values of dryland pastoralists and conservation needs for small mammals. Conservation Biology, 31(2), pp.331-342.

Adriansen, H.K., 2008. Understanding pastoral mobility: the case of Senegalese Fulani. Geographical Journal, 174(3), pp.207-222.

Ahmed, F., 2018. Conceptualizing subsistence as a response to capitalist violence against African indigenous women. Agenda, 32(4), pp.22-31.

Ahmed, M.J. and Murtaza, G., 2015. A study of medicinal plants used as ethnoveterinary: harnessing potential phytotherapy in Bheri, district Muzaffarabad (Pakistan). Journal of ethnopharmacology, 159, pp.209-214.

Akinyemi, F.O., 2017. Climate change and variability in Semiarid Palapye, Eastern Botswana: An assessment from smallholder farmers' perspective. Weather, Climate, and Society, 9(3), pp.349-365.

Akogun, O.B., Gundiri, M.A., Badaki, J.A., Njobdi, S.Y., Adesina, A.O. and Ogundahunsi, O.T., 2012. Febrile illness experience among Nigerian nomads. International journal for equity in health, 11(1), pp.110 .

Aktay, L., Sözüer, Ö., Horns, J.J., Kökenek, D., Tomas, B.K. and Şekercioğlu, Ç.H., 2017. Behavioural and morphological characteristics of white doves in Osmaniye, Turkey identify the population as Laughing Doves (Streptopelia senegalensis). Zoology in the Middle East, 63(3), pp.189-193.

Altaf, M., Umair, M., Abbasi, A.R., Muhammad, N. and Abbasi, A.M., 2018. Ethnomedicinal applications of animal species by the local communities of Punjab, Pakistan. Journal of ethnobiology and ethnomedicine, 14(1), pp.1-25.

Álvares, F., Domingues, J., Sierra, P. and Primavera, P., 2011. Cultural dimension of wolves in the Iberian Peninsula: implications of ethnozoology in conservation biology. Innovation: The European Journal of Social Science Research, 24(3), pp.313-331.

Amadi, J.A., Olago, D.O., Ong'amo, G.O., Oriaso, S.O., Nyamongo, I.K. and Estambale, B.B., 2018. "We don't want our clothes to smell smoke": changing malaria control practices and opportunities for integrated community-based management in Baringo, Kenya. BMC public health, 18(1), pp.1-14.

Amenu, K., Szonyi, B., Grace, D. and Wieland, B., 2017. Important knowledge gaps among pastoralists on causes and treatment of udder health problems in livestock in southern Ethiopia: results of qualitative investigation. BMC veterinary research, 13(1), pp.1-13. 
Anadón, J.D., Giménez, A. and Ballestar, R., 2010. Linking local ecological knowledge and habitat modelling to predict absolute species abundance on large scales. Biodiversity and Conservation, 19(5), pp.1443-1454.

Anadón, J.D., Giménez, A., Ballestar, R. and Pérez, I., 2009. Evaluation of local ecological knowledge as a method for collecting extensive data on animal abundance. Conservation biology, 23(3), pp.617-625.

Andersen, G.L., Krzywinski, K., Talib, M., Saadallah, A.E., Hobbs, J.J. and Pierce, R.H., 2014. Traditional nomadic tending of trees in the Red Sea Hills. Journal of Arid Environments, 106, pp.36-44.

Andersson, R., Östlund, L. and Lundqvist, R., 2005. Carved trees in grazed forests in boreal Swedenanalysis of remaining trees, interpretation of past land-use and implications for conservation. Vegetation History and Archaeobotany, 14(2), pp.149-158.

Andom, G. and Omer, M.K., 2003. Traditional cattle-husbandry systems in Eritrea: cattle-man relationships. Journal of arid environments, 53(4), pp.545-556.

Angassa, A. and Beyene, F., 2003. Current range condition in southern Ethiopia in relation to traditional management strategies: the perceptions of Borana pastoralists. Tropical Grasslands, 37(1), pp.53-59.

Angassa, A. and Oba, G., 2008. Herder perceptions on impacts of range enclosures, crop farming, fire ban and bush encroachment on the rangelands of Borana, Southern Ethiopia. Human ecology, 36(2), pp.201215.

Anthonj, C., Diekkrüger, B., Borgemeister, C. and Kistemann, T., 2019. Health risk perceptions and local knowledge of water-related infectious disease exposure among Kenyan wetland communities. International journal of hygiene and environmental health, 222(1), pp.34-48.

Apio, A., Umuntunundi, P., Lerp, H., Bierbach, D., Plath, M. and Wronski, T., 2015. Persistence of two small antelope species in the degraded Mutara Rangelands (Akagera Ecosystem) based on pastoralists' and farmers' perceptions. Human Ecology, 43(4), pp.613-620.

Axelsson Linkowski, W., Kvarnström, M., Westin, A., Moen, J. and Östlund, L., 2017. Wolf and bear depredation on livestock in Northern Sweden 1827-2014: combining history, ecology and interviews. Land, 6(3), p.63.

Ayantunde, A.A., Briejer, M., Hiernaux, P., Udo, H.M. and Tabo, R., 2008. Botanical knowledge and its differentiation by age, gender and ethnicity in Southwestern Niger. Human Ecology, 36(6), pp.881-889.

Ayantunde, A.A., de Leeuw, J., Turner, M.D. and Said, M., 2011. Challenges of assessing the sustainability of (agro)-pastoral systems. Livestock Science, 139(1-2), pp.30-43.

Ayantunde, A.A., Kango, M., Hiernaux, P., Udo, H.M. and Tabo, R., 2007. Herders' perceptions on ruminant livestock breeds and breeding management in southwestern Niger. Human Ecology, 35(1), pp.139-149.

Aziz, M.A., Khan, A.H., Adnan, M. and Ullah, H., 2018. Traditional uses of medicinal plants used by Indigenous communities for veterinary practices at Bajaur Agency, Pakistan. Journal of ethnobiology and ethnomedicine, 14(1), pp.1-18.

Báez, J.C., Estrada, A., Torreblanca, D. and Real, R., 2012. Predicting the distribution of cryptic species: the case of the spur-thighed tortoise in Andalusia (southern Iberian Peninsula). Biodiversity and Conservation, 21(1), pp.65-78.

Balbo, A.L., Gómez-Baggethun, E., Salpeteur, M., Puy, A., Biagetti, S. and Scheffran, J., 2016. Resilience of small-scale societies: a view from drylands. Ecology and Society, 21(2). 
Balehegn, M., Balehey, S., Fu, C. and Liang, W., 2019. Indigenous weather and climate forecasting knowledge among Afar pastoralists of north eastern Ethiopia: Role in adaptation to weather and climate variability. Pastoralism, 9(1), pp.1-14.

Barber, M., Jackson, S., Shellberg, J. and Sinnamon, V., 2014. Working Knowledge: characterising collective indigenous, scientific, and local knowledge about the ecology, hydrology and geomorphology of Oriners Station, Cape York Peninsula, Australia. The Rangeland Journal, 36(1), pp.53-66.

Barrow, E.G.C., 1991. Evaluating the effectiveness of participatory agroforestry extension programmes in a pastoral system, based on existing traditional values. Agroforestry Systems, 14(1), pp.1-21.

Basupi, L.V., Quinn, C.H. and Dougill, A.J., 2017. Historical perspectives on pastoralism and land tenure transformation in Ngamiland, Botswana: What are the policy and institutional lessons?. Pastoralism, 7(1), pp.1-14.

Baucus, D.A., Baucus, M.S. and Human, S.E., 1996. Consensus in franchise organizations: A cooperative arrangement among entrepreneurs. Journal of Business venturing, 11(5), pp.359-378.

Bayazit, O.B., Lien, J.M. and Amato, N.M., 2004, July. Swarming behavior using probabilistic roadmap techniques. In International Workshop on Swarm Robotics (pp. 112-125). Springer, Berlin, Heidelberg.

Behmanesh, B., Barani, H., Sarvestani, A.A., Shahraki, M.R. and Sharafatmandrad, M., 2016. Rangeland degradation assessment: a new strategy based on the ecological knowledge of indigenous pastoralists. Solid Earth, 7(2), pp.611-619.

Belayneh, A., Asfaw, Z., Demissew, S. and Bussa, N.F., 2012. Medicinal plants potential and use by pastoral and agro-pastoral communities in Erer Valley of Babile Wereda, Eastern Ethiopia. Journal of Ethnobiology and Ethnomedicine, 8(1), pp.1-11.

Benjaminsen, T.A., Reinert, H., Sjaastad, E. and Sara, M.N., 2015. Misreading the Arctic landscape: A political ecology of reindeer, carrying capacities, and overstocking in Finnmark, Norway. Norsk Geografisk Tidsskrift-Norwegian Journal of Geography, 69(4), pp.219-229.

Bennett, D. and Ross, C., 2011. Fulani of the highlands: Costs and benefits of living in national park enclaves. In Primates of Gashaka (pp. 283-317). Springer, New York, NY.

Berry, E., Metternicht, G. and Baumber, A., 2019. 'This country just hangs tight': perspectives on managing land degradation and climate change in far west NSW. The Rangeland Journal, 41(3), pp.197-210.

Bewsell, D., Mackay, A., Kaye-Blake, W., Dynes, R., Montes de Oca Munguia, O. and Brown, M., 2017. Collaborative processes for exploring rural futures: The Exploring Futures Platform. Rural Society, 26(1), pp.48-68.

Biagetti, S., 2017. Resilience in a Mountain Range: The Case of the Tadrart Acacus (Southwest Libya). Nomadic Peoples, 21(2), pp.268-285.

Biró, M., Molnár, Z., Babai, D., Dénes, A., Fehér, A., Barta, S., Sáfián, L., Szabados, K., Kiš, A., Demeter, L. and Öllerer, K., 2019. Reviewing historical traditional knowledge for innovative conservation management: A re-evaluation of wetland grazing. Science of the Total Environment, 666, pp.1114-1125.

Blanco, J. and Carrière, S.M., 2016. Sharing local ecological knowledge as a human adaptation strategy to arid environments: Evidence from an ethnobotany survey in Morocco. Journal of Arid Environments, 127, pp.30-43.

Bobiec, A., Podlaski, R., Ortyl, B., Korol, M., Havryliuk, S., Öllerer, K., Ziobro, J.M., Pilch, K., Dychkevych, V., Dudek, T. and Mázsa, K., 2019. Top-down segregated policies undermine the maintenance of traditional wooded landscapes: evidence from oaks at the European Union's eastern border. Landscape and Urban Planning, 189, pp.247-259. 
Boesi, A., 2014. Traditional knowledge of wild food plants in a few Tibetan communities. Journal of Ethnobiology and Ethnomedicine, 10(1), pp.1-19.

Bollig, M. and Österle, M., 2008. Changing communal land tenure in an East African pastoral system: Institutions and socio-economic transformations among the Pokot of NW Kenya. Zeitschrift für Ethnologie, pp.301-322.

Bollig, M. and Schulte, A., 1999. Environmental change and pastoral perceptions: degradation and indigenous knowledge in two African pastoral communities. Human ecology, 27(3), pp.493-514.

Bolton, M., 2006. Genetic defects or generative prototypes? Competing models for livestock improvement in southern Bolivia. Journal of the Royal Anthropological Institute, 12(3), pp.531-549.

Brännlund, I. and Axelsson, P., 2011. Reindeer management during the colonization of Sami lands: A longterm perspective of vulnerability and adaptation strategies. Global Environmental Change, 21(3), pp.1095-1105.

Brook, R.K., Vander Wal, E., van Beest, F.M. and McLachlan, S.M., 2013. Evaluating use of cattle winter feeding areas by elk and white-tailed deer: implications for managing bovine tuberculosis transmission risk from the ground up. Preventive Veterinary Medicine, 108(2-3), pp.137-147.

Bruegger, R.A., Jigjsuren, O. and Fernández-Gimenez, M.E., 2014. Herder observations of rangeland change in Mongolia: indicators, causes, and application to community-based management. Rangeland Ecology \& Management, 67(2), pp.119-131.

Bruyere, B.L., Trimarco, J. and Lemungesi, S., 2016. A comparison of traditional plant knowledge between students and herders in northern Kenya. Journal of ethnobiology and ethnomedicine, 12(1), pp.1-10.

Butt, B., 2016. Ecology, mobility and labour: Dynamic pastoral herd management in an uncertain world. Rev. Sci. Tech, 35, pp.461-472.

Butz, D., 1996. Sustaining indigenous communities: symbolic and instrumental dimensions of pastoral resource use in Shimshal, northern Pakistan. Canadian Geographer/Le Géographe canadien, 40(1), pp.3653.

Butz, R.J., 2009. Traditional fire management: historical fire regimes and land use change in pastoral East Africa. International Journal of Wildland Fire, 18(4), pp.442-450.

Campbell, D., 2011. Application of an integrated multidisciplinary economic welfare approach to improved wellbeing through Aboriginal caring for country. The Rangeland Journal, 33(4), pp.365-372.

Caplins, L. and Halvorson, S.J., 2017. Collecting Ophiocordyceps sinensis: an emerging livelihood strategy in the Garhwal, Indian Himalaya. Journal of Mountain Science, 14(2), pp.390-402.

Catley, A., 2006. Use of participatory epidemiology to compare the clinical veterinary knowledge of pastoralists and veterinarians in East Africa. Tropical animal health and production, 38(3), pp.171-184.

Chandrasekhar, K., Rao, K.S., Maikhuri, R.K. and Saxena, K.G., 2007. Ecological implications of traditional livestock husbandry and associated land use practices: A case study from the trans-Himalaya, India. Journal of Arid Environments, 69(2), pp.299-314.

Chenais, E. and Fischer, K., 2018. Increasing the local relevance of epidemiological research: situated knowledge of cattle disease among Basongora pastoralists in Uganda. Frontiers in veterinary science, 5, p.119.

Cogos, S., Östlund, L. and Roturier, S., 2019. Forest fire and indigenous Sami land use: place names, fire dynamics, and ecosystem change in Northern Scandinavia. Human Ecology, 47(1), pp.51-64.

Crate, S.A., 2006. Elder knowledge and sustainable livelihoods in post-Soviet Russia: Finding dialogue across the generations. Arctic Anthropology, 43(1), pp.40-51. 
Crate, S.A., 2008. Walking behind the old women: Sacred Sakha cow knowledge in the 21st Century. Human Ecology Review, 15(2), p.115.

Crawley, J.A., Lahdenperä, M., Seltmann, M.W., Htut, W., Aung, H.H., Nyein, K. and Lummaa, V., 2019. Investigating changes within the handling system of the largest semi-captive population of Asian elephants. PloS one, 14(1), p.e0209701.

Cuerrier, A., Brunet, N.D., Gérin-Lajoie, J., Downing, A. and Lévesque, E., 2015. The study of Inuit knowledge of climate change in Nunavik, Quebec: a mixed methods approach. Human ecology, 43(3), pp.379-394.

Davis, D., 1996. Gender, indigenous knowledge, and pastoral resource use in Morocco. Geographical Review, 86(2), pp.284-288.

Davis, D.K., 2005. Indigenous knowledge and the desertification debate: problematising expert knowledge in North Africa. Geoforum, 36(4), pp.509-524.

Davis, D.K., 2016. Political economy, power, and the erasure of pastoralist indigenous knowledge in the Maghreb and Afghanistan. In Ethnic and Cultural Dimensions of Knowledge (pp. 211-228). Springer, Cham.

Davis, D.K., Quraishi, K., Sherman, D., Sollod, A. and Stem, C., 1995. Ethnoveterinary medicine in Afghanistan: an overview of indigenous animal health care among Pashtun Koochi nomads. Journal of Arid Environments, 31(4), pp.483-500.

Day, M.J., Karkare, U., Schultz, R.D., Squires, R. and Tsujimoto, H., 2015. Recommendations on vaccination for Asian small animal practitioners: a report of the WSAVA Vaccination Guidelines Group. Journal of Small Animal Practice, 56(2), pp.77-95.

Defoort, M., Kokosy, A., Floquet, T., Perruquetti, W. and Palos, J., 2009. Motion planning for cooperative unicycle-type mobile robots with limited sensing ranges: A distributed receding horizon approach. Robotics and autonomous systems, 57(11), pp.1094-1106.

Del Valle M, M., Ibarra, J.T., Hörmann, P.A., Hernández, R. and Riveros F, J.L., 2019. Local Knowledge for Addressing Food Insecurity: The Use of a Goat Meat Drying Technique in a Rural Famine Context in Southern Africa. Animals, 9(10), p.808.

Della, A., Paraskeva-Hadjichambi, D. and Hadjichambis, A.C., 2006. An ethnobotanical survey of wild edible plants of Paphos and Larnaca countryside of Cyprus. Journal of ethnobiology and ethnomedicine, 2(1), pp.1-9.

Dendoncker, M., Ngom, D. and Vincke, C., 2015. Trees dynamics (1955-2012) and their uses in the Senegal's Ferlo region: insights from a historical vegetation database, local knowledge and field inventories. Bois et Forêts des Tropiques, (326), pp.25-41.

Dolrenry, S., Hazzah, L. and Frank, L.G., 2016. Conservation and monitoring of a persecuted African lion population by Maasai warriors. Conservation Biology, 30(3), pp.467-475.

Dong, S., 2017. Himalayan grasslands: Indigenous knowledge and institutions for social innovation. In Environmental Sustainability from the Himalayas to the Oceans (pp. 99-126). Springer, Cham.

Dong, S., Lassoie, J., Shrestha, K.K., Yan, Z., Sharma, E. and Pariya, D., 2009. Institutional development for sustainable rangeland resource and ecosystem management in mountainous areas of northern Nepal. Journal of Environmental Management, 90(2), pp.994-1003.

Dong, S., Sharma, E., Yan, Z.L., Shrestha, K.K. and Pariya, D., 2020. Indigenous Yak and Yak-Cattle Crossbreed Management in High Altitude Areas of Northern Nepal: A Case Study from Rasuwa District. AFRICAN JOURNAL OF AGRICULTURAL RESEARCH, 4(10), pp. 957-967. 
Dong, S.K., Lassoie, J.P., Yan, Z.L., Sharma, E., Shrestha, K.K. and Pariya, D., 2007. Indigenous rangeland resource management in the mountainous areas of northern Nepal: a case study from the Rasuwa District. The Rangeland Journal, 29(2), pp.149-160.

Dudi, A. and Meena, M.L., 2015. Ethnoveterinary medicines used by goat keepers in Marwar region of Rajasthan, India. Indian Journal of Traditional Knowledge, 14(3),pp.454-460.

Duenn, P., Salpeteur, M. and Reyes-García, V., 2017. Rabari shepherds and the mad tree: The dynamics of local ecological knowledge in the context of Prosopis juliflora invasion in Gujarat, India. Journal of Ethnobiology, 37(3), pp.561-580.

Duncan, D.H., Kyle, G. and Race, D., 2010. Combining facilitated dialogue and spatial data analysis to compile landscape history. Environmental Conservation, pp.432-441.

Dutt, H.C., Bhagat, N. and Pandita, S., 2015. Oral traditional knowledge on medicinal plants in jeopardy among Gaddi shepherds in hills of northwestern Himalaya, J\&K, India. Journal of ethnopharmacology, 168 , pp.337-348.

Easdale, M.H. and Aguiar, M.R., 2018. From traditional knowledge to novel adaptations of transhumant pastoralists the in face of new challenges in North Patagonia. Journal of Rural Studies, 63, pp.65-73.

Eddy, I.M., Gergel, S.E., Coops, N.C., Henebry, G.M., Levine, J., Zerriffi, H. and Shibkov, E., 2017. Integrating remote sensing and local ecological knowledge to monitor rangeland dynamics. Ecological Indicators, 82, pp.106-116.

Egeru, A., Wasonga, O., Mburu, J., Yazan, E., Majaliwa, M.G., MacOpiyo, L. and Bamutaze, Y., 2015. Drivers of forage availability: An integration of remote sensing and traditional ecological knowledge in Karamoja sub-region, Uganda. Pastoralism, 5(1), pp.1-18.

Eloy, L., Schmidt, I.B., Borges, S.L., Ferreira, M.C. and Dos Santos, T.A., 2019. Seasonal fire management by traditional cattle ranchers prevents the spread of wildfire in the Brazilian Cerrado. Ambio, 48(8), pp.890-899.

Endris Ahmed, M. and Ahmed Bihi, M., 2019. Indigenous knowledge for resilience and adaptation in pastoral production system of Somali Regional State in Ethiopia. Interdisciplinary Description of Complex Systems: INDECS, 17(4), pp.723-737.

Evangelista, P.H., Mohamed, A.M., Hussein, I.A., Saied, A.H., Mohammed, A.H. and Young, N.E., 2018. Integrating indigenous local knowledge and species distribution modeling to detect wildlife in Somaliland. Ecosphere, 9(3), p.e02134.

Evans, K.E. and Harris, S., 2008. Adolescence in male African elephants, Loxodonta africana, and the importance of sociality. Animal Behaviour, 76(3), pp.779-787.

Evelyn, M., 2005. The role of ethnoveterinary medicine in livestock production. ANIMAL PRODUCTION AND ANIMAL SCIENCE WORLDWIDE: WAAP BOOK OF THE YEAR, 2: 257-269.

Farooquee, N.A. and Nautiyal, A., 1999. Traditional knowledge and practices of Bhotiya pastoralists of Kumaon Himalaya: the need for value addition. International Journal of Sustainable Development \& World Ecology, 6(1), pp.60-67.

Fassnacht, S.R., Allegretti, A.M., Venable, N.B., Fernández-Giménez, M.E., Tumenjargal, S., Kappas, M., Laituri, M.J., Batbuyan, B. and Pfohl, A.K., 2018. Merging indigenous knowledge systems and station observations to estimate the uncertainty of precipitation change in central Mongolia. Hydrology, 5(3), p.46.

Ferguson, J., 2012. A sustainable future for the Australian rangelands. The Rangeland Journal, 34(1), pp.2732. 
Fernández-Giménez, M.E. and Estaque, F.F., 2012. Pyrenean pastoralists' ecological knowledge: documentation and application to natural resource management and adaptation. Human Ecology, 40(2), pp.287-300.

Fernandez-Gimenez, M.E., 2000. THE ROLE OF MONGOLIAN NOMADIC PASTORALISTS'ECOLOGICAL KNOWLEDGE IN RANGELAND MANAGEMENT. Ecological applications, 10(5), pp.1318-1326.

Fernández-Giménez, M.E., 2015. "A shepherd has to invent” Poetic analysis of social-ecological change in the cultural landscape of the central Spanish Pyrenees. Ecology and Society, 20(4).

Ferrier, J., Saciragic, L., Trakić, S., Chen, E.C., Gendron, R.L., Cuerrier, A., Balick, M.J., Redžić, S., Alikadić, E. and Arnason, J.T., 2015. An ethnobotany of the Lukomir highlanders of Bosnia \& Herzegovina. Journal of ethnobiology and ethnomedicine, 11(1), pp.1-17.

Feyera, T., Mekonnen, E., Wakayo, B.U. and Assefa, S., 2017. Botanical ethnoveterinary therapies used by agro-pastoralists of Fafan zone, Eastern Ethiopia. BMC veterinary research, 13(1), pp.1-11.

Forbes, B.C. and Stammler, F., 2009. Arctic climate change discourse: the contrasting politics of research agendas in the West and Russia. Polar Research, 28(1), pp.28-42.

Forrest, I., 2011. The archive of the official of Stow and the 'machinery'of church government in the late thirteenth century. Historical Research, 84(223), pp.1-13.

Frascaroli, F., Bhagwat, S. and Diemer, M., 2014. Healing animals, feeding souls: Ethnobotanical values at sacred sites in Central Italy. Economic Botany, 68(4), pp.438-451.

French, K.E., 2017. Species composition determines forage quality and medicinal value of high diversity grasslands in lowland England. Agriculture, Ecosystems \& Environment, 241, pp.193-204.

French, K.E., 2018. Plant-based solutions to global livestock anthelmintic resistance. Ethnobiology Letters, 9(2), pp.110-123.

Fu, Y., Grumbine, R.E., Wilkes, A., Wang, Y., Xu, J.C. and Yang, Y.P., 2012. Climate change adaptation among Tibetan pastoralists: challenges in enhancing local adaptation through policy support. Environmental management, 50(4), pp.607-621.

Furberg, M., Hondula, D.M., Saha, M.V. and Nilsson, M., 2018. In the light of change: a mixed methods investigation of climate perceptions and the instrumental record in northern Sweden. Population and environment, 40(1), pp.47-71.

Gabalebatse, M., Ngwenya, B.N., Teketay, D. and Kolawole, O.D., 2013. Ethno-veterinary practices amongst livestock farmers in Ngamiland District, Botswana. African Journal of Traditional, Complementary and Alternative Medicines, 10(3), pp.490-502.

Gachathi, F.N. and Eriksen, S., 2011. Gums and resins: The potential for supporting sustainable adaptation in Kenya's drylands. Climate and Development, 3(1), pp.59-70.

Gaerrang, K., 2017. Tibetan Buddhism, Wetland Transformation, and Environmentalism in Tibetan Pastoral Areas of Western China. Conservation and Society, 15(1), pp.14-23.

Gaoue, O.G. and Ticktin, T., 2009. Fulani knowledge of the ecological impacts of Khaya senegalensis (Meliaceae) foliage harvest in Benin and its implications for sustainable harvest. Economic Botany, 63(3), pp.256-270.

Gebresenbet, F. and Kefale, A., 2012. Traditional coping mechanisms for climate change of pastoralists in South Omo, Ethiopia. Indian Journal of Traditional Knowledge, 11(4), pp. 573-579. 
Gemedo-Dalle, Isselstein, J. and Maass, B.L., 2006. Indigenous ecological knowledge of Borana pastoralists in southern Ethiopia and current challenges. The International Journal of Sustainable Development and World Ecology, 13(2), pp.113-130.

Gemedo-Dalle, T., Maass, B.L. and Isselstein, J., 2005. Plant biodiversity and ethnobotany of Borana pastoralists in southern Oromia, Ethiopia. Economic botany, 59(1), pp.43-65.

Genin, D., Crochot, C., MSou, S., Araba, A. and Alifriqui, M., 2016. Meadow up a tree: Feeding flocks with a native ash tree in the Moroccan mountains. Pastoralism, 6(1), pp.1-12.

Genin, D., M'Sou, S., Ferradous, A. and Alifriqui, M., 2018. Another vision of sound tree and forest management: Insights from traditional ash shaping in the Moroccan Berber mountains. Forest ecology and management, 429, pp.180-188.

Gentle, P. and Thwaites, R., 2016. Transhumant pastoralism in the context of socioeconomic and climate change in the mountains of Nepal. Mountain Research and Development, 36(2), pp.173-182.

Geraci, A., Amato, F., Di Noto, G., Bazan, G. and Schicchi, R., 2018. The wild taxa utilized as vegetables in Sicily (Italy): a traditional component of the Mediterranean diet. Journal of ethnobiology and ethnomedicine, 14(1), pp.1-27.

Ghorbani, M., Azarnivand, H., Mehrabi, A.A., Jafari, M., Nayebi, H. and Seeland, K., 2013. The role of indigenous ecological knowledge in managing rangelands sustainably in northern Iran. Ecology and Society, 18(2).

Ghorbani, M., Mehrabi, A.A., Azarnivand, H., Bastani, S., Jafari, M. and Seeland, K., 2015. Communal institutions for the management of rangeland resources and dairy production in Taleghan Valley, Northern Iran. The Rangeland Journal, 37(2), pp.169-179.

Ghufran, M.A., Batool, A., Ali, M., Iqbal, Z., Fakhar-i-Abbas, Ashraf, M. and Qureshi, R.A., 2010. Geographical barriers and their influence on indiginous knowledge of local flora. Pakistan Journal of Botany, 42, pp.309-317.

Giday, M. and Teklehaymanot, T., 2013. Ethnobotanical study of plants used in management of livestock health problems by Afar people of Ada'ar District, Afar Regional State, Ethiopia. Journal of Ethnobiology and Ethnomedicine, 9(1), pp.1-10.

Gilchrist, H.G. and Robertson, G.J., 2000. Observations of marine birds and mammals wintering at polynyas and ice edges in the Belcher Islands, Nunavut, Canada. Arctic, pp.61-68.

Gill, N., 2003. Environmental (re) education and local environmental knowledge: statutory ground-based monitoring and pastoral culture in central Australia. The Rangeland Journal, 25(1), pp.85-104.

Gil-Romera, G., Lamb, H.F., Turton, D., Sevilla-Callejo, M. and Umer, M., 2010. Long-term resilience, bush encroachment patterns and local knowledge in a Northeast African savanna. Global Environmental Change, 20(4), pp.612-626.

Gil-Romera, G., Turton, D. and Sevilla-Callejo, M., 2011. Landscape change in the lower Omo valley, southwestern Ethiopia: burning patterns and woody encroachment in the savanna. Journal of Eastern African Studies, 5(1), pp.108-128.

Gobindram, N.E., Boughalmi, A., Moulin, C.H., Meuret, M., Bastianelli, D., Araba, A. and Jouven, M., 2018. Feeding flocks on rangelands: insights into the local ecological knowledge of shepherds in Boulemane province (Morocco). The Rangeland Journal, 40(3), pp.207-218.

Goldman, M., 2007. Tracking wildebeest, locating knowledge: Maasai and conservation biology understandings of wildebeest behavior in Northern Tanzania. Environment and Planning D: Society and space, 25(2), pp.307-331. 
Guarrera, P.M., Savo, V. and Caneva, G., 2015. Traditional uses of plants in the Tolfa-Cerite-Manziate area (Central Italy). Ethnobiology Letters, 6(1), pp.119-161.

Gutierrez-Peña, R., Mena, Y., Ruiz, F.A. and Delgado-Pertíñez, M., 2016. Strengths and weaknesses of traditional feeding management of dairy goat farms in mountain areas. Agroecology and Sustainable Food Systems, 40(7), pp.736-756.

Hall, M., 2016. Terra Nullius: Colonial Violence in Prynne's Acrylic Tips. Journal of British and Irish Innovative Poetry, 8(1).

Hansen, K.K., Moldenæs, T. and Mathiesen, S.D., 2019. The knowledge that went up in smoke: Reindeer herders' traditional knowledge of smoked reindeer meat in literature. Polar Record, 55(6), pp.460-475.

Hayashi, K., Abdoulaye, T., Matsunaga, R. and Tobita, S., 2009. Appraisal of local farmers' practices on land management for a guideline of agricultural development in the Sahel zone of Niger, West Africa. Japan Agricultural Research Quarterly: JARQ, 43(1), pp.63-69.

Hazzah, L., Dolrenry, S., Naughton, L., Edwards, C.T., Mwebi, O., Kearney, F. and Frank, L., 2014. Efficacy of two lion conservation programs in Maasailand, Kenya. Conservation Biology, 28(3), pp.851860.

Hernández-Morcillo, M., Hoberg, J., Oteros-Rozas, E., Plieninger, T., Gómez-Baggethun, E. and ReyesGarcía, V., 2014. Traditional ecological knowledge in Europe: status quo and insights for the environmental policy agenda. Environment: Science and Policy for Sustainable Development, 56(1), pp.3-17.

Hewitt, K., 2014. Glaciers in human life. In Glaciers of the Karakoram Himalaya (pp. 327-351). Springer, Dordrecht.

Hobbs, J.J., Krzywinski, K., Andersen, G.L., Talib, M., Pierce, R.H. and Saadallah, A.E., 2014. Acacia trees on the cultural landscapes of the Red Sea Hills. Biodiversity and conservation, 23(12), pp.2923-2943.

Homann, S., Rischkowsky, B. and Steinbach, J., 2008. The effect of development interventions on the use of indigenous range management strategies in the Borana Lowlands in Ethiopia. Land Degradation \& Development, 19(4), pp.368-387.

Homann, S., Rischkowsky, B., Steinbach, J., Kirk, M. and Mathias, E., 2008. Towards endogenous livestock development: Borana pastoralists' responses to environmental and institutional changes. Human Ecology, 36(4), p.503.

Hopping, K.A., Yangzong, C. and Klein, J.A., 2016. Local knowledge production, transmission, and the importance of village leaders in a network of Tibetan pastoralists coping with environmental change. Ecology and Society, 21(1).

Hosseininia, G.H., Azadi, H., Zarafshani, K., Samari, D. and Witlox, F., 2013. Sustainable rangeland management: Pastoralists' attitudes toward integrated programs in Iran. Journal of Arid Environments, 92, pp.26-33.

Houessou, S.O., Dossa, L.H., Diogo, R.V.C., Ahozonlin, M.C., Dahouda, M. and Schlecht, E., 2019. Confronting pastoralists' knowledge of cattle breeds raised in the extensive production systems of Benin with multivariate analyses of morphological traits. PloS one, 14(9), p.e0222756.

Hounet, B., Brisebarre, A.M. and Guinand, S., 2016. The cultural heritage of pastoralism-local knowledge, state identity and the global perspective: the example of local breeds in Morocco. Revue scientifique et technique (International Office of Epizootics), 35(2), pp.357-370.

Huang, X.H., Zhou, Y.Z., Fang, J.P. and Hou, L., 2019. Climate change has more adverse impacts on the higher mountain communities than the lower ones: people's perception from the northern Himalayas. Journal of Mountain Science, 16(11), pp.2625-2639. 
Hunde, D., 2012. Use s and management of Ximenia americana, Olacaceae in semi-arid East Shewa, Ethiopia. PAKISTAN JOURNAL OF BOTANY, 44: 1177-1184.

Hutchins, K.G., 2019. Like a Lullaby: Song as Herding Tool in Rural Mongolia. Journal of Ethnobiology, 39(3), pp.445-459.

Iegorova, L.V., Gibbs, J.P., Mountrakis, G., Bastille-Rousseau, G., Paltsyn, M.Y., Ayatkhan, A., Baylagasov, L.V., Robertus, Y.V. and Chelyshev, A.V., 2019. Rangeland vegetation dynamics in the Altai Mountain region of Mongolia, Russia, Kazakhstan and China: Effects of climate, topography, and socio-political context for livestock herding practices. Environmental Research Letters, 14(10), p.104017.

Iniesta-Arandia, I., Del Amo, D.G., García-Nieto, A.P., Pineiro, C., Montes, C. and Martín-López, B., 2015. Factors influencing local ecological knowledge maintenance in Mediterranean watersheds: Insights for environmental policies. Ambio, 44(4), pp.285-296.

Irons, D.B., 1998. Foraging area fidelity of individual seabirds in relation to tidal cycles and flock feeding. Ecology, 79(2), pp.647-655.

Iticha, B. and Husen, A., 2019. Adaptation to climate change using indigenous weather forecasting systems in Borana pastoralists of southern Ethiopia. Climate and Development, 11(7), pp.564-573.

Jamsranjav, C., Fernández-Giménez, M.E., Reid, R.S. and Adya, B., 2019. Opportunities to integrate herders' indicators into formal rangeland monitoring: an example from Mongolia. Ecological Applications, 29(5), p.e01899.

Jandreau, C. and Berkes, F., 2016. Continuity and change within the social-ecological and political landscape of the Maasai Mara, Kenya. Pastoralism, 6(1), pp.1-15.

Johansson, M.U., Fetene, M., Malmer, A. and Granström, A., 2012. Tending for cattle: traditional fire management in Ethiopian montane heathlands. Ecology and Society, 17(3).

Joshi, S., Jasra, W.A., Ismail, M., Shrestha, R.M., Yi, S.L. and Wu, N., 2013. Herders' perceptions of and responses to climate change in northern Pakistan. Environmental management, 52(3), pp.639-648.

Kabzung, G., 2017. Contested understandings of yaks on the eastern Tibetan Plateau: market logic, Tibetan Buddhism and indigenous knowledge. Area, 49(4).

Kagunyu, A., Wandibba, S. and Wanjohi, J.G., 2016. The use of indigenous climate forecasting methods by the pastoralists of Northern Kenya. Pastoralism, 6(1), pp.1-6.

Kakinuma, K., Okayasu, T., Jamsran, U., Okuro, T. and Takeuchi, K., 2014. Herding strategies during a drought vary at multiple scales in Mongolian rangeland. Journal of arid environments, 109, pp.88-91.

Kakinuma, K., Sasaki, T., Jamsran, U., Okuro, T. and Takeuchi, K., 2014. Relationship between pastoralists' evaluation of rangeland state and vegetation threshold changes in Mongolian rangelands. Environmental management, 54(4), pp.888-896.

Kassahun, A., Snyman, H.A. and Smit, G.N., 2008. Livestock grazing behaviour along a degradation gradient in the Somali region of eastern Ethiopia. African Journal of Range and forage science, 25(1), pp.1-9.

Kassam, K.A., 2009. Viewing change through the prism of indigenous human ecology: findings from the Afghan and Tajik Pamirs. Human Ecology, 37(6), pp.677-690.

Katjiua, M. and Ward, D., 2007. Pastoralists' perceptions and realities of vegetation change and browse consumption in the northern Kalahari, Namibia. Journal of Arid Environments, 69(4), pp.716-730.

Kaushik, G. and Sharma, K.C., 2015. Climate change and rural livelihoods-adaptation and vulnerability in Rajasthan. Global NEST Journal, 17(1), pp.41-49. 
Kebede, E., Mengistu, M. and Serda, B., 2018. Ethnobotanical knowledge of pastoral community for treating livestock diseases in Somali regional state, eastern Ethiopia. Tropical animal health and production, 50(6), pp.1379-1386.

Kenny, T.A., Fillion, M., Simpkin, S., Wesche, S.D. and Chan, H.M., 2018. Caribou (Rangifer tarandus) and Inuit nutrition security in Canada. EcoHealth, 15(3), pp.590-607.

Kerario, I.I., Simuunza, M., Laisser, E.L. and Chenyambuga, S., 2018. Exploring knowledge and management practices on ticks and tick-borne diseases among agro-pastoral communities in Southern Highlands, Tanzania. Veterinary world, 11(1), p.48.

Kerber, J., 2015. Caribou, Petroleum, and the Limits of Locality in the Canada-US Borderlands. American Review of Canadian Studies, 45(3), pp.332-345.

Kgosikoma, O., Mojeremane, W. and Harvie, B.A., 2012. Pastoralists' perception and ecological knowledge on savanna ecosystem dynamics in semi-arid Botswana. Ecology and Society, 17(4).

Khan, M.A., Khan, M.A., Mujtaba, G. and Hussain, M., 2012. Ethnobotanical study about medicinal plants of Poonch valley Azad Kashmir. J animal plant Sci, 22, pp.493-500.

Kibet, S., Nyangito, M., MacOpiyo, L. and Kenfack, D., 2016. Tracing innovation pathways in the management of natural and social capital on Laikipia Maasai Group Ranches, Kenya. Pastoralism, 6(1), pp.1-13.

Kikvidze, Z. and Tevzadze, G., 2015. Loss of traditional knowledge aggravates wolf-human conflict in Georgia (Caucasus) in the wake of socio-economic change. Ambio, 44(5), pp.452-457.

Kimiti, K.S., Wasonga, O.V., Western, D. and Mbau, J.S., 2016. Community perceptions on spatio-temporal land use changes in the Amboseli ecosystem, southern Kenya. Pastoralism, 6(1), pp.1-10.

King, E.G. and Franz, T.E., 2016. Combining ecohydrologic and transition probability-based modeling to simulate vegetation dynamics in a semi-arid rangeland. Ecological Modelling, 329, pp.41-63.

Kiptot, E., 2007. Eliciting indigenous knowledge on tree fodder among Maasai pastoralists via a multimethod sequencing approach. Agriculture and Human Values, 24(2), pp.231-243.

Kitchell, E., 2016. Information sharing and climate risk management among Senegalese agropastoralists. Climate and Development, 8(2), pp.158-168.

Klein, D.R., Moorehead, L., Kruse, J. and Braund, S.R., 1999. Contrasts in use and perceptions of biological data for caribou management. Wildlife Society Bulletin, pp.488-498.

Klein, J.A., Hopping, K.A., Yeh, E.T., Nyima, Y., Boone, R.B. and Galvin, K.A., 2014. Unexpected climate impacts on the Tibetan Plateau: local and scientific knowledge in findings of delayed summer. Global Environmental Change, 28, pp.141-152.

Klubnikin, K., Annett, C., Cherkasova, M., Shishin, M. and Fotieva, I., 2000. The sacred and the scientific: traditional ecological knowledge in Siberian river conservation. Ecological Applications, 10(5), pp.12961306.

Kong, T.M., Austin, D.E., Kellner, K. and Orr, B.J., 2014. The interplay of knowledge, attitude and practice of livestock farmers' land management against desertification in the South African Kalahari. Journal of arid Environments, 105, pp.12-21.

Krupnik, I., Pratt, K.L. and Mager, K.H., 2012. "I'd Be Foolish to Tell You They Were Caribou”: Local Knowledge of Historical Interactions between Reindeer and Caribou in Barrow, Alaska. Arctic anthropology, 49(2), pp.162-181. 
Kruse, J.A., White, R.G., Epstein, H.E., Archie, B., Berman, M., Braund, S.R., Chapin, F.S., Charlie, J., Daniel, C.J., Eamer, J. and Flanders, N., 2004. Modeling sustainability of arctic communities: an interdisciplinary collaboration of researchers and local knowledge holders. Ecosystems, 7(8), pp.815-828.

Kugonza, D.R., Kiwuwa, G.H., Mpairwe, D., Jianlin, H., Nabasirye, M., Okeyo, A.M. and Hanotte, O., 2012. Accuracy of pastoralists' memory-based kinship assignment of Ankole cattle: a microsatellite DNA analysis. Journal of Animal Breeding and Genetics, 129(1), pp.30-40.

Kugonza, D.R., Nabasirye, M., Hanotte, O., Mpairwe, D. and Okeyo, A.M., 2012. Pastoralists' indigenous selection criteria and other breeding practices of the long-horned Ankole cattle in Uganda. Tropical animal health and production, 44(3), pp.557-565.

Kumpula, T., Forbes, B.C. and Stammler, F., 2010. Remote sensing and local knowledge of hydrocarbon exploitation: the case of Bovanenkovo, Yamal Peninsula, West Siberia, Russia. Arctic, pp.165-178.

Kuriyan, R., 2002. Linking local perceptions of elephants and conservation: Samburu pastoralists in northern Kenya. Society \&Natural Resources, 15(10), pp.949-957.

Ladio, A.H. and Lozada, M., 2009. Human ecology, ethnobotany and traditional practices in rural populations inhabiting the Monte region: resilience and ecological knowledge. Journal of Arid Environments, 73(2), pp.222-227.

Laverty, T.M., Teel, T.L., Thomas, R.E., Gawusab, A.A. and Berger, J., 2019. Using pastoral ideology to understand human-wildlife coexistence in arid agricultural landscapes. Conservation Science and Practice, 1(5), p.e35.

Liao, C., Ruelle, M.L. and Kassam, K.A.S., 2016. Indigenous ecological knowledge as the basis for adaptive environmental management: Evidence from pastoralist communities in the Horn of Africa. Journal of Environmental Management, 182, pp.70-79.

Lima, M., Christie, D.A., Santoro, M.C. and Latorre, C., 2016. Coupled socio-environmental changes triggered indigenous aymara depopulation of the semiarid Andes of Tarapacá-Chile during the late 19th20th centuries. PLoS One, 11(8), p.e0160580.

Linstädter, A., Bora, Z., Tolera, A. and Angassa, A., 2016. Are trees of intermediate density more facilitative? Canopy effects of four East African legume trees. Applied Vegetation Science, 19(2), pp.291-303.

Linstädter, A., Kemmerling, B., Baumann, G. and Kirscht, H., 2013. The importance of being reliable-local ecological knowledge and management of forage plants in a dryland pastoral system (Morocco). Journal of Arid Environments, 95, pp.30-40.

Liu, G., 2013. Wild plant folk nomenclature of the Mongol herdsmen in the Arhorchin national nature reserve, Inner Mongolia, PR China. Journal of ethnobiology and ethnomedicine, 9(1), pp.1-11.

Ljubicic, G., Okpakok, S., Robertson, S. and Mearns, R., 2018. Inuit approaches to naming and distinguishing caribou: Considering language, place, and homeland toward improved co-management. Arctic, 71(3), pp.309-333.

Ljubicic, G., Okpakok, S., Robertson, S. and Mearns, R., 2018. Uqsuqtuurmiut inuita tuktumi qaujimaningit (Inuit knowledge of caribou from Gjoa Haven, Nunavut): Collaborative research contributions to comanagement efforts. The Polar Record, 54(3), pp.213-233.

Loseto, L.L., Brewster, J.D., Ostertag, S.K., Snow, K., MacPhee, S.A., McNicholl, D.G., Choy, E.S., Giraldo, C. and Hornby, C.A., 2018. Diet and feeding observations from an unusual beluga harvest in 2014 near Ulukhaktok, Northwest Territories, Canada. Arctic Science, 4(3), pp.421-431. 
Low, B., Sundaresan, S.R., Fischhoff, I.R. and Rubenstein, D.I., 2009. Partnering with local communities to identify conservation priorities for endangered Grevy's zebra. Biological Conservation, 142(7), pp.15481555.

Luizza, M.W., Wakie, T., Evangelista, P.H. and Jarnevich, C.S., 2016. Integrating local pastoral knowledge, participatory mapping, and species distribution modeling for risk assessment of invasive rubber vine (Cryptostegia grandiflora) in Ethiopia's Afar region. Ecology and Society, 21(1).

Lyver, P.O.B., Taputu, T.M., Kutia, S.T. and Tahi, B., 2008. Tūhoe Tuawhenua mātauranga of kererū (Hemiphaga novaseelandiae novaseelandiae) in Te Urewera. New Zealand Journal of Ecology, pp.7-17.

Macharia, P.N., 2004. Community based interventions as a strategy to combat desertification in the arid and semi-arid rangelands of Kajiado District, Kenya. Environmental monitoring and assessment, 99(1), pp.141-147.

Magige, F. and Røskaft, E., 2017. Medicinal and commercial uses of ostrich products in Tanzania. Journal of ethnobiology and ethnomedicine, 13(1), pp.1-7.

Maiti, S., Chakravarty, P., Garai, S., Bandyopadhyay, S. and Chouhan, V.S., 2013. Ethno-veterinary practices for ephemeral fever of Yak: A participatory assessment by the Monpa tribe of Arunachal Pradesh. Indian Journal of Traditional Knowledge, 12(1), pp.36-39.

Mangesho, P.E., Neselle, M.O., Karimuribo, E.D., Mlangwa, J.E., Queenan, K., Mboera, L.E., Rushton, J., Kock, R., Häsler, B., Kiwara, A. and Rweyemamu, M., 2017. Exploring local knowledge and perceptions on zoonoses among pastoralists in northern and eastern Tanzania. PLoS neglected tropical diseases, 11(2), p.e0005345.

Mapinduzi, A.L., Oba, G., Weladji, R.B. and Colman, J.E., 2003. Use of indigenous ecological knowledge of the Maasai pastoralists for assessing rangeland biodiversity in Tanzania. African journal of Ecology, 41(4), pp.329-336.

Marin, A., 2010. Riders under storms: contributions of nomadic herders' observations to analysing climate change in Mongolia. Global Environmental Change, 20(1), pp.162-176.

Markkula, I., Turunen, M. and Kantola, S., 2019. Traditional and local knowledge in land use planning: insights into the use of the Akwé: Kon Guidelines in Eanodat, Finnish Sápmi. Ecology and Society, 24(1).

Marshall, N.A., 2011. Assessing resource dependency on the rangelands as a measure of climate sensitivity. Society \& Natural Resources, 24(10), pp.1105-1115.

Materechera, S.A., 2010. Utilization and management practices of animal manure for replenishing soil fertility among smallscale crop farmers in semi-arid farming districts of the North West Province, South Africa. Nutrient cycling in agroecosystems, 87(3), pp.415-428.

Maynard, N.G., Oskal, A., Turi, J.M., Mathiesen, S.D., Eira, I.M.G., Yurchak, B., Etylin, V. and Gebelein, J., 2010. Impacts of arctic climate and land use changes on reindeer pastoralism: indigenous knowledge and remote sensing. In Eurasian Arctic land cover and land use in a changing climate (pp. 177-205). Springer, Dordrecht.

Meena, R.P., Meena, B.L., Nandal, U. and Meena, C.L., 2014. Indigenous measures developed by farmers to curb the menace of blue bull (Boselaphus tragocamelus) in district Rajsamand, Rajasthan, India. Indian Journal of Traditional Knowledge, 13(1),pp.208-215.

Mekonnen, Z., Kassa, H., Woldeamanuel, T. and Asfaw, Z., 2018. Analysis of observed and perceived climate change and variability in Arsi Negele District, Ethiopia. Environment, Development and Sustainability, 20(3), pp.1191-1212. 
Mekuria, S., Zerihun, A., Gebre-Egziabher, B. and Tibbo, M., 2008. Participatory investigation of Contagious Caprine Pleuropneumonia (CCPP) in goats in the Hammer and Benna-Tsemay districts of southern Ethiopia. Tropical animal health and production, 40(8), pp.571-582.

Metcalf, V. and Robards, M., 2008. Sustaining a healthy human-walrus relationship in a dynamic environment: challenges for comanagement. Ecological Applications, 18(sp2), pp.S148-S156.

Miara, M.D., Bendif, H., Ouabed, A., Rebbas, K., Hammou, M.A., Amirat, M., Greene, A. and TeixidorToneu, I., 2019. Ethnoveterinary remedies used in the Algerian steppe: Exploring the relationship with traditional human herbal medicine. Journal of ethnopharmacology, 244, p.112164.

Mogotsi, K., Moroka, A.B., Sitang, O. and Chibua, R., 2011. Seasonal precipitation forecasts: Agroecological knowledge among rural Kalahari communities. African Journal of Agricultural Research, 6(4), pp.916-922.

Mogotsi, K., Nyangito, M.M. and Nyariki, D.M., 2013. The role of drought among agro-pastoral communities in a semi-arid environment: the case of Botswana. Journal of arid environments, 91, pp.3844.

Molnár, Z., 2013. Traditional vegetation knowledge of the Hortobágy salt steppe (Hungary): a neglected source of information for vegetation science and conservation. Phytocoenologia, 43(3-4), pp.193-205.

Molnár, Z., 2014. Perception and management of spatio-temporal pasture heterogeneity by Hungarian herders. Rangeland Ecology \& Management, 67(2), pp.107-118.

Molnár, Z., 2017. "I see the grass through the mouths of my animals"-Folk indicators of pasture plants used by traditional steppe herders. Journal of Ethnobiology, 37(3), pp.522-541.

Morales-Reyes, Z., Martín-López, B., Moleón, M., Mateo-Tomás, P., Olea, P.P., Arrondo, E., Donázar, J.A. and Sánchez-Zapata, J.A., 2019. Shepherds' local knowledge and scientific data on the scavenging ecosystem service: Insights for conservation. Ambio, 48(1), pp.48-60.

Morojele, P., 2017. Indigenous knowledge/s of survival: Implications for lifelong learning among the Basotho herding fraternity. Educational Research for Social Change, 6(1), pp.38-55.

Morrison, B.J., Gold, M.A. and Lantagne, D.O., 1996. Incorporating indigenous knowledge of fodder trees into small-scale silvopastoral systems in Jamaica. Agroforestry systems, 34(1), pp.101-117.

Mortimore, M., 2010. Adapting to drought in the Sahel: lessons for climate change. Wiley interdisciplinary reviews: climate change, 1(1), pp.134-143.

Mortimore, M., 2016. Changing paradigms for people-centred development in the Sahel. In The End of Desertification? (pp. 65-98). Springer, Berlin, Heidelberg.

Mtuy, T.B., Burton, M.J., Mwingira, U., Ngondi, J.M., Seeley, J. and Lees, S., 2019. Knowledge, perceptions and experiences of trachoma among Maasai in Tanzania: Implications for prevention and control. PLoS neglected tropical diseases, 13(6), p.e0007508.

Muhammad, M.S., Abdullah, M., Khan, M.S., Javed, K. and Jabbar, M.A., 2015. FARMERS'PREFERENCES FOR GOAT BREEDS IN PUNJAB, PAKISTAN. The Journal of Animal \& Plant Sciences, 25(2), pp.380-386.

Müller, B., Linstädter, A., Frank, K., Bollig, M. and Wissel, C., 2007. Learning from local knowledge: modeling the pastoral-nomadic range management of the Himba, Namibia. Ecological Applications, 17(7), pp.1857-1875.

Mvungi, A., Mashauri, D. and Madulu, N.F., 2005. Management of water for irrigation agriculture in semiarid areas: Problems and prospects. Physics and Chemistry of the Earth, Parts A/B/C, 30(11-16), pp.809817. 
Mwaura, F. and Kaburu, H.M., 2009. Spatial variability in woody species richness along altitudinal gradient in a lowland-dryland site, Lokapel Turkana, Kenya. Biodiversity and conservation, 18(1), pp.19-32.

Naah, J.B.S. and Braun, B., 2019. Local agro-pastoralists' perspectives on forage species diversity, habitat distributions, abundance trends and ecological drivers for sustainable livestock production in West Africa. Scientific reports, 9(1), pp.1-11.

Naah, J.B.S. and Guuroh, R.T., 2017. Factors influencing local ecological knowledge of forage resources: ethnobotanical evidence from West Africa's savannas. Journal of environmental management, 188, pp.297-307.

Naah, J.B.S., 2018. Investigating criteria for valuation of forage resources by local agro-pastoralists in West Africa: using quantitative ethnoecological approach. Journal of ethnobiology and ethnomedicine, 14(1), pp.1-16.

Ng'asike, J.T. and Swadener, B.B., 2015. Turkana indigenous knowledge: Environmental sustainability and pastoralist lifestyle for economic survival. In Indigenous Innovation (pp. 107-127). Brill Sense.

Ng'asike, J.T., 2019. Indigenous knowledge practices for sustainable lifelong education in pastoralist communities of Kenya. International review of education, 65(1), pp.19-46.

Ng'asike, J.T., 2014. African early childhood development curriculum and pedagogy for Turkana nomadic pastoralist communities of Kenya. New directions for child and adolescent development, 2014(146), pp.43-60.

Nkonya, E. and Anderson, W., 2015. Exploiting provisions of land economic productivity without degrading its natural capital. Journal of Arid Environments, 112, pp.33-43.

Nkuba, M., Chanda, R., Mmopelwa, G., Kato, E., Mangheni, M.N. and Lesolle, D., 2019. The effect of climate information in pastoralists' adaptation to climate change. International Journal of Climate Change Strategies and Management.

Notenbaert, A., Karanja, S.N., Herrero, M., Felisberto, M. and Moyo, S., 2013. Derivation of a householdlevel vulnerability index for empirically testing measures of adaptive capacity and vulnerability. Regional Environmental Change, 13(2), pp.459-470.

Nuru, H. and Fielding, D., 1993. Traditional knowledge and practices in calf rearing. Appropriate Technology, 20(3), pp.33-35.

Nyima, Y. and Hopping, K.A., 2019. Tibetan lake expansion from a pastoral perspective: local observations and coping strategies for a changing environment. Society \& Natural Resources, 32(9), pp.965-982.

Oba, G. and Kaitira, L.M., 2006. Herder knowledge of landscape assessments in arid rangelands in northern Tanzania. Journal of Arid environments, 66(1), pp.168-186.

Oba, G. and Kotile, D.G., 2001. Assessments of landscape level degradation in southern Ethiopia: pastoralists versus ecologists. Land Degradation \& Development, 12(5), pp.461-475.

Oba, G., Byakagaba, P. and Angassa, A., 2008. Participatory monitoring of biodiversity in East African grazing lands. Land Degradation \& Development, 19(6), pp.636-648.

Oba, G., Sjaastad, E. and Roba, H.G., 2008. Framework for participatory assessments and implementation of global environmental conventions at the community level. Land Degradation \& Development, 19(1), pp.65-76.

Ogbaharya, D. and Tecle, A., 2010. Community-based natural resources management in Eritrea and Ethiopia: toward a comparative institutional analysis. Journal of Eastern African Studies, 4(3), pp.490509. 
Oinam, S.S., Rawat, Y.S., Kuniyal, J.C., Vishvakarma, S.C.R. and Pandey, D.C., 2008. Thermal supplementing soil nutrients through biocomposting of night-soil in the northwestern Indian Himalaya. Waste management, 28(6), pp.1008-1019.

Osue, H.O., Lawani, F.A.G. and Njoku, C.I., 2018. Factors affecting sustainable animal trypanosomosis control in parts of Kaduna State, Nigeria. Journal of Agricultural Extension, 22(1), pp.1-14.

Oteros-Rozas, E., Martín-López, B., López, C.A., Palomo, I. and González, J.A., 2013. Envisioning the future of transhumant pastoralism through participatory scenario planning: a case study in Spain. The Rangeland Journal, 35(3), pp.251-272.

Oteros-Rozas, E., Ontillera-Sánchez, R., Sanosa, P., Gómez-Baggethun, E., Reyes-García, V. and González, J.A., 2013. Traditional ecological knowledge among transhumant pastoralists in Mediterranean Spain. Ecology and Society, 18(3).

Padilla, E. and Kofinas, G.P., 2014. "Letting the leaders pass" barriers to using traditional ecological knowledge in comanagement as the basis of formal hunting regulations. Ecology and Society, 19(2).

Paltsyn, M.Y., Gibbs, J.P. and Mountrakis, G., 2019. Integrating traditional ecological knowledge and remote sensing for monitoring rangeland dynamics in the Altai Mountain region. Environmental management, 64(1), pp.40-51.

Panikkar, B., Lemmond, B., Else, B. and Murray, M., 2018. Ice over troubled waters: navigating the Northwest Passage using Inuit knowledge and scientific information. Climate Research, 75(1), pp.81-94.

Pape, R. and Loeffler, J., 2016. BROAD-SCALE ASSUMPTIONS ON AVAILABLE PASTURE RESOURCES AND REINDEER'S HABITAT PREFERENCES SHOWN TO BE DECOUPLED FROM ECOLOGICAL REALITY OF ARCTIC-ALPINE LANDSCAPES. Erdkunde, pp.169-192.

Parker, G.E., Davidson, Z., Low, B., Lalampaa, P.R., Sundaresan, S. and Fischer, M., 2017. Can pastoral communities offer solutions for conserving the Endangered Grevy's zebra Equus grevyi at the periphery of its range?. Oryx, 51(3), pp.517-526.

Parlee, B., Manseau, M. and Łutsël K'é Dene First Nation, 2005. Using traditional knowledge to adapt to ecological change: Denésǫłıné monitoring of Caribou movements. Arctic, pp.26-37.

Parlee, B.L., Sandlos, J. and Natcher, D.C., 2018. Undermining subsistence: Barren-ground caribou in a "tragedy of open access". Science Advances, 4(2), p.e1701611.

Patria, H.D., 2013. Uncultivated Biodiversity in Women's Hand: How to Create Food Sovereignty. Asian Journal of Women's Studies, 19(2), pp.148-161.

Pieroni, A., Howard, P., Volpato, G. and Santoro, R.F., 2004. Natural remedies and nutraceuticals used in ethnoveterinary practices in inland southern Italy. Veterinary research communications, 28(1), pp.55-80.

Pitikoe, S., 2017. Basotho herders learn through culture and social interaction. Learning, culture and social interaction, 13, pp.104-112.

Pitikoe, S., 2018. Turning the herding lifestyle into a learning opportunity: experiences from Lesotho. TD: The Journal for Transdisciplinary Research in Southern Africa, 14(1), pp.1-10.

Plieninger, T., Hartel, T., Martín-López, B., Beaufoy, G., Bergmeier, E., Kirby, K., Montero, M.J., Moreno, G., Oteros-Rozas, E. and Van Uytvanck, J., 2015. Wood-pastures of Europe: Geographic coverage, social-ecological values, conservation management, and policy implications. Biological Conservation, 190, pp.70-79.

Pomalégni, S.C.B., Gbemavo, D.S.J.C., Kpadé, C.P., Kenis, M. and Mensah, G.A., 2017. Traditional use of fly larvae by small poultry farmers in Benin. Journal of Insects as Food and Feed, 3(3), pp.187-192.

Post, J.C., 2018. Climate Change and Cultural Heritage in Western Mongolia. Leonardo, 51(03), pp.285-286. 
Post, J.C., 2019. Songs, Settings, Sociality: Human and Ecological Well-Being in Western Mongolia. Journal of Ethnobiology, 39(3), pp.371-391.

Pristupa, A.O., Lamers, M., Tysiachniouk, M. and Amelung, B., 2019. Reindeer Herders Without Reindeer. The Challenges of Joint Knowledge Production on Kolguev Island in the Russian Arctic. Society \& Natural Resources, 32(3), pp.338-356.

Pulina, G., Salimei, E., Masala, G. and Sikosana, J.L.N., 1999. A spreadsheet model for the assessment of sustainable stocking rate in semi-arid and sub-humid regions of Southern Africa. Livestock Production Science, 61(2-3), pp.287-299.

Rachman, Ali MA. "Indigenous Knowledge between Collapsion and Prospect of Genetic Conservation and Development." In Proceding [Proceeding] of the Mini Workshop Southeast Asia Germany Alumni Network (SEAG)" Empowering of Society Through the Animal Health and Production Activities with the Appreciation to the Indigenous Knowledge": May 3rd-5, 2007, Manado-Indonesia, vol. 90, p. 15. kassel university press $\mathrm{GmbH}, 2008$.

Radeny, M., Desalegn, A., Mubiru, D., Kyazze, F., Mahoo, H., Recha, J., Kimeli, P. and Solomon, D., 2019. Indigenous knowledge for seasonal weather and climate forecasting across East Africa. Climatic Change, 156(4), pp.509-526.

Rahimi, R., Abdollahi, F. and Naqshi, K., 2014. Time-varying formation control of a collaborative heterogeneous multi agent system. Robotics and autonomous systems, 62(12), pp.1799-1805.

Rajabu, K.R., 2005. The role of participatory problem analysis in performance improvement and sustainable management of rainwater harvesting (RWH) systems: A case study of Makanya village, Tanzania. Physics and Chemistry of the Earth, Parts A/B/C, 30(11-16), pp.832-839.

Rana, D., Bhatt, A. and Lal, B., 2019. Ethnobotanical knowledge among the semi-pastoral Gujjar tribe in the high altitude (Adhwari's) of Churah subdivision, district Chamba, Western Himalaya. Journal of ethnobiology and ethnomedicine, 15(1), pp.1-21.

Rana, P.K., Kumar, P., Singhal, V.K. and Rana, J.C., 2014. Uses of local plant biodiversity among the tribal communities of Pangi Valley of district Chamba in cold desert Himalaya, India. The Scientific World Journal, 2014.

Raziq, A., de Verdier, K. and Younas, M., 2010. Ethnoveterinary treatments by dromedary camel herders in the Suleiman Mountainous Region in Pakistan: an observation and questionnaire study. Journal of ethnobiology and ethnomedicine, 6(1), pp.1-12.

Reed, M.S. and Dougill, A.J., 2002. Participatory selection process for indicators of rangeland condition in the Kalahari. Geographical Journal, 168(3), pp.224-234.

Reed, M.S., Dougill, A.J. and Baker, T.R., 2008. Participatory indicator development: what can ecologists and local communities learn from each other. Ecological Applications, 18(5), pp.1253-1269.

Reed, M.S., Dougill, A.J. and Taylor, M.J., 2007. Integrating local and scientific knowledge for adaptation to land degradation: Kalahari rangeland management options. Land Degradation \& Development, 18(3), pp.249-268.

Rees, W.G., Williams, M. and Vitebsky, P., 2003. Mapping land cover change in a reindeer herding area of the Russian Arctic using Landsat TM and ETM+ imagery and indigenous knowledge. Remote Sensing of Environment, 85(4), pp.441-452.

Reid, R.S., Nkedianye, D., Said, M.Y., Kaelo, D., Neselle, M., Makui, O., Onetu, L., Kiruswa, S., Kamuaro, N.O., Kristjanson, P. and Ogutu, J., 2016. Evolution of models to support community and policy action with science: Balancing pastoral livelihoods and wildlife conservation in savannas of East Africa. Proceedings of the National Academy of Sciences, 113(17), pp.4579-4584. 
Reyes-García, V., Fernández-Llamazares, Á., Guèze, M. and Gallois, S., 2018. Does weather forecasting relate to foraging productivity? An empirical test among three hunter-gatherer societies. Weather, Climate, and Society, 10(1), pp.163-177.

Rippa, D., Maselli, V., Soppelsa, O. and Fulgione, D., 2011. The impact of agro-pastoral abandonment on the Rock Partridge Alectoris graeca in the Apennines. Ibis, 153(4), pp.721-734.

Riseth, J.Å., Tømmervik, H., Helander-Renvall, E., Labba, N., Johansson, C., Malnes, E., Bjerke, J.W., Jonsson, C., Pohjola, V., Sarri, L.E. and Schanche, A., 2011. Sámi traditional ecological knowledge as a guide to science: snow, ice and reindeer pasture facing climate change. The Polar Record, 47(3), p.202.

Roba, H. and Oba, G., 2010. FRAMEWORK FOR INTEGRATING INDIGENOUS KNOWLEDGE AND ECOLOGICAL METHODS FOR IMPLEMENTATION OF DESERTIFICATION CONVENTION. GRASSLAND BIODIVERSITY: HABITAT TYPES, ECOLOGICAL PROCESSES AND ENVIRONMENTAL IMPACT, 135-177.

Roba, H.G. and Oba, G., 2008. Integration of herder knowledge and ecological methods for land degradation assessment around sedentary settlements in a sub-humid zone in northern Kenya. The International Journal of Sustainable Development \& World Ecology, 15(3), pp.251-264.

Roba, H.G. and Oba, G., 2009. Community participatory landscape classification and biodiversity assessment and monitoring of grazing lands in northern Kenya. Journal of Environmental Management, 90(2), pp.673-682.

Roba, H.G. and Oba, G., 2009. Efficacy of integrating herder knowledge and ecological methods for monitoring rangeland degradation in northern Kenya. Human Ecology, 37(5), pp.589-612.

Robbins, P., 2003. Beyond ground truth: GIS and the environmental knowledge of herders, professional foresters, and other traditional communities. Human Ecology, 31(2), pp.233-253.

Rogers, P., Nunan, F. and Fentie, A.A., 2017. Reimagining invasions: The social and cultural impacts of Prosopis on pastoralists in southern Afar, Ethiopia. Pastoralism, 7(1), pp.1-13.

Roschinsky, R., Mulindwa, H., Galukande, E., Wurzinger, M., Mpairwe, D., Okeyo, A.M. and Sölkner, J., 2012. Pasture use and management strategies in the Ankole pastoral system in Uganda. Grass and Forage Science, 67(2), pp.199-209.

Roturier, S. and Roué, M., 2009. Of forest, snow and lichen: Sámi reindeer herders' knowledge of winter pastures in northern Sweden. Forest Ecology and Management, 258(9), pp.1960-1967.

Ruotsala, H., 2011. Ancestors' Wisdom or Desktop Reindeer Management? The Role of Traditional Ecological Knowledge in Contemporary Reindeer Herding. Thinking through the Environment, Green Approaches to Global History. Timo Myllyntaus, ed, pp.159-178.

Russell, D., Kofinas, G. and Griffith, B., 2000. Need and opportunity for a North American caribou knowledge cooperative. Polar Research, 19(1), pp.117-129.

Saboohi, R., Barani, H., Khodagholi, M., Sarvestani, A.A. and Tahmasebi, A., 2019. Nomads' indigenous knowledge and their adaptation to climate changes in Semirom City in Central Iran. Theoretical and Applied Climatology, 137(1), pp.1377-1384.

Salman, A. and Kharusi, N.S., 2014. Female Camel Nomenclature among Arabia's Bedouins. Names, 62(2), pp.86-99.

Salomon, M., Cupido, C. and Samuels, I., 2013. The good shepherd: remedying the fencing syndrome. African Journal of Range \& Forage Science, 30(1-2), pp.71-75.

Salpeteur, M., Patel, H., Balbo, A.L., Rubio-Campillo, X., Madella, M., Ajithprasad, P. and Reyes-García, V., 2015. When knowledge follows blood: kin groups and the distribution of traditional ecological 
knowledge in a community of seminomadic pastoralists, Gujarat (India). Current Anthropology, 56(3), pp.471-483.

Salpeteur, M., Patel, H.H., Molina, J.L., Balbo, A.L., Rubio-Campillo, X., Reyes-García, V. and Madella, M., 2016. Comigrants and friends: informal networks and the transmission of traditional ecological knowledge among seminomadic pastoralists of Gujarat, India. Ecology and Society, 21(2).

Samuels, M.I., Swarts, M., Schroeder, A., Ntombela, K. and Cupido, C., 2018. Through the lens of a herder: insights into landscape ethno-ecological knowledge on rangelands in Namaqualand. Anthropology Southern Africa, 41(2), pp.136-152.

Sandström, P., Pahlén, T.G., Edenius, L., Tømmervik, H., Hagner, O., Hemberg, L., Olsson, H., Baer, K., Stenlund, T., Brandt, L.G. and Egberth, M., 2003. Conflict resolution by participatory management: remote sensing and GIS as tools for communicating land-use needs for reindeer herding in northern Sweden. AMBIO: A Journal of the Human Environment, 32(8), pp.557-567.

Sanon, H.O., Kaboré-Zoungrana, C. and Ledin, I., 2007. Behaviour of goats, sheep and cattle and their selection of browse species on natural pasture in a Sahelian area. Small ruminant research, 67(1), pp.6474.

Sawadogo, L., Tiveau, D. and Nygård, R., 2005. Influence of selective tree cutting, livestock and prescribed fire on herbaceous biomass in the savannah woodlands of Burkina Faso, West Africa. Agriculture, ecosystems \& environment, 105(1-2), pp.335-345.

Schareika, N., 2014. The social nature of environmental knowledge among the nomadic Wodaabe of Niger. Ecology and Society, 19(4).

Schmidt, M. and Pearson, O., 2016. Pastoral livelihoods under pressure: Ecological, political and socioeconomic transitions in Afar (Ethiopia). Journal of Arid Environments, 124, pp.22-30.

Seid, M.A., Kuhn, N.J. and Fikre, T.Z., 2016. The role of pastoralism in regulating ecosystem services. Revue scientifique et technique (International Office of Epizootics), 35(2), pp.435-444.

Seid, M.A., Yoseph, L.W., Befekadu, U.W., Muhammed, A. and Fikre, T.Z., 2016. Communication for the development of pastoralism. Revue scientifique et technique (International Office of Epizootics), 35(2), pp.639-648.

Seijo, F., Millington, J.D., Gray, R., Sanz, V., Lozano, J., García-Serrano, F., Sangüesa-Barreda, G. and Camarero, J.J., 2015. Forgetting fire: Traditional fire knowledge in two chestnut forest ecosystems of the Iberian Peninsula and its implications for European fire management policy. Land Use Policy, 47, pp.130144.

Seonyatseng, E., Mogwera, K.M., Mpofu, C., Ntloyathuto, D. and Rutina, L.P., 2017. Herders' ecological knowledge and carnivore predation on livestock investigations in Makgadikgadi and Nxai national parks, Botswana. Koedoe: African Protected Area Conservation and Science, 59(2), pp.1-9.

Setchell, J.M., Fairet, E., Shutt, K., Waters, S. and Bell, S., 2017. Biosocial conservation: Integrating biological and ethnographic methods to study human-primate interactions. International journal of primatology, 38(2), pp.401-426.

Shackleton, R.T., Witt, A.B., Piroris, F.M. and van Wilgen, B.W., 2017. Distribution and socio-ecological impacts of the invasive alien cactus Opuntia stricta in eastern Africa. Biological Invasions, 19(8), pp.2427-2441.

Shen, X. and Tan, J., 2012. Ecological conservation, cultural preservation, and a bridge between: the journey of Shanshui Conservation Center in the Sanjiangyuan region, Qinghai-Tibetan Plateau, China. Ecology and Society, 17(4). 
Sher, H., Aldosari, A. and Bussmann, R.W., 2015. Morels of Palas Valley, Pakistan: a potential source for generating income and improving livelihoods of mountain communities. Economic Botany, 69(4), pp.345-359.

Sherren, K. and Darnhofer, I., 2018. Precondition for integration: in support of stand-alone social science in rangeland and silvopastoral research. Rangeland ecology \& management, 71(5), pp.545-548.

Sheuyange, A., Oba, G. and Weladji, R.B., 2005. Effects of anthropogenic fire history on savanna vegetation in northeastern Namibia. Journal of Environmental management, 75(3), pp.189-198.

Shmatkov, N. and Brigham, T., 2003. Non-timber forest products in community development: Lessons from the Russian Far East. The Forestry Chronicle, 79(1), pp.113-118.

Singh, D., Kachhawaha, S., Choudhary, M.K., Meena, M.L. and Tomar, P.K., 2014. Ethnoveterinary knowledge of Raikas of Marwar for nomadic pastoralism. Indian Journal of Traditional Knowledge, 13(1),pp.123-131.

Singh, R.K., 2010. Learning the indigenous knowledge and biodiversity through contest: A participatory methodological tool of ecoliteracy. Indian Journal of Traditional Knowledge, 9(2), pp.355-360.

Singh, R.K., Singh, A., Garnett, S.T., Zander, K.K. and Tsering, D., 2015. Paisang (Quercus griffithii): a keystone tree species in sustainable agroecosystem management and livelihoods in Arunachal Pradesh, India. Environmental management, 55(1), pp.187-204.

Singh, R.K., Sureja, A.K., Maiti, S. and Tsering, D., 2018. Grazing and rangeland management: trans-human adaptations by Brokpa community in fragile ecosystems of Arunachal Pradesh, Indian Journal of Traditional Knowledge, 17(3), pp. 550-558.

Skarin, A., Danell, Ö., Bergström, R. and Moen, J., 2008. Summer habitat preferences of GPS-collared reindeer Rangifer tarandus tarandus. Wildlife Biology, 14(1), pp.1-15.

Smucker, T.A. and Wangui, E.E., 2016. Gendered knowledge and adaptive practices: Differentiation and change in Mwanga District, Tanzania. Ambio, 45(3), pp.276-286.

Solh, M., Amri, A., Ngaido, T. and Valkoun, J., 2003. Policy and education reform needs for conservation of dryland biodiversity. Journal of Arid Environments, 54(1), pp.5-13.

Soma, T. and Schlecht, E., 2018. The relevance of herders' local ecological knowledge on coping with livestock losses during harsh winters in western Mongolia. Pastoralism, 8(1), pp.1-14.

Soria-Díaz, L. and Monroy-Vilchis, O., 2015. Monitoring population density and activity pattern of whitetailed deer (Odocoileus virginianus) in Central Mexico, using camera trapping. Mammalia, 79(1), pp.4350.

Speranza, C.I., Kiteme, B., Ambenje, P., Wiesmann, U. and Makali, S., 2010. Indigenous knowledge related to climate variability and change: insights from droughts in semi-arid areas of former Makueni District, Kenya. Climatic change, 100(2), pp.295-315.

Spoon, J., 2011. The heterogeneity of Khumbu Sherpa ecological knowledge and understanding in Sagarmatha (Mount Everest) national park and buffer zone, Nepal. Human Ecology, 39(5), p.657.

Spooner, P.G. and Firman, M., 2010. Origins of travelling stock routes. 1. Connections to indigenous traditional pathways. The Rangeland Journal, 32(3), pp.329-339.

Stave, J., Oba, G., Nordal, I. and Stenseth, N.C., 2007. Traditional ecological knowledge of a riverine forest in Turkana, Kenya: implications for research and management. Biodiversity and Conservation, 16(5), pp.1471-1489.

Stephens, P.R., Hewitt, A.E., Sparling, G.P., Gibb, R.G. and Shepherd, T.G., 2003. Assessing sustainability of land management using a risk identification model. 土壤圈 (英文版), (2003 年 01), pp.41-48. 
Strauch, A.M. and Almedom, A.M., 2011. Traditional water resource management and water quality in rural Tanzania. Human Ecology, 39(1), pp.93-106.

Surová, D., Ravera, F., Guiomar, N., Sastre, R.M. and Pinto-Correia, T., 2018. Contributions of iberian silvo-pastoral landscapes to the well-being of contemporary society. Rangeland Ecology \& Management, 71(5), pp.560-570.

Takakura, H., 2002. An institutionalized human-animal relationship and the aftermath: The reproductive process of horse-bands and husbandry in Northern Yakutia, Siberia. Human Ecology, 30(1), pp.1-19.

Takakura, H., 2012. The shift from herding to hunting among the Siberian Evenki: Indigenous knowledge and subsistence change in Northwestern Yakutia. Asian Ethnology, 71(1), p.31.

Tambe, S. and Rawat, G.S., 2009. Traditional livelihood based on sheep grazing in the Khangchendzonga national park, Sikkim. Indian Journal of Traditional Knowledge, 8(1), pp. 75-80.

Tamou, C., de Boer, I.J., Ripoll-Bosch, R. and Oosting, S.J., 2018. Understanding roles and functions of cattle breeds for pastoralists in Benin. Livestock Science, 210, pp.129-136.

Tamou, C., De Boer, I.J.M., Ripoll-Bosch, R. and Oosting, S.J., 2018. Traditional ecological knowledge underlying herding decisions of pastoralists. Animal, 12(4), pp.831-843.

Tang, R. and Gavin, M.C., 2010. Traditional ecological knowledge informing resource management: saxoul conservation in Inner Mongolia, China. Society and Natural Resources, 23(3), pp.193-206.

Tang, R. and Gavin, M.C., 2015. Degradation and re-emergence of the commons: The impacts of government policies on traditional resource management institutions in China. Environmental Science \& Policy, 52, pp.89-98.

Tanyanyiwa, V.I., 2019. Indigenous Knowledge Systems and the Teaching of Climate Change in Zimbabwean Secondary Schools. SAGE Open, 9(4), p.2158244019885149.

Taylor, J.L., 2006. Negotiating the grassland: the policy of pasture enclosures and contested resource use in Inner Mongolia. Human Organization, pp.374-386.

Teklehaymanot, T. and Giday, M., 2010. Quantitative ethnobotany of medicinal plants used by Kara and Kwego semi-pastoralist people in lower Omo River Valley, Debub Omo zone, southern nations, nationalities and peoples regional state, Ethiopia. Journal of Ethnopharmacology, 130(1), pp.76-84.

Teklehaymanot, T., 2017. An ethnobotanical survey of medicinal and edible plants of Yalo Woreda in Afar regional state, Ethiopia. Journal of Ethnobiology and Ethnomedicine, 13(1), pp.1-26.

Tesfai, M. and Stroosnijder, L., 2001. The Eritrean spate irrigation system. Agricultural water management, 48(1), pp.51-60.

Tian, X., 2017. Ethnobotanical knowledge acquisition during daily chores: the firewood collection of pastoral Maasai girls in Southern Kenya. Journal of ethnobiology and ethnomedicine, 13(1), pp.1-14.

Tiki, W., Oba, G. and Tvedt, T., 2011. Human stewardship or ruining cultural landscapes of the ancient Tula wells, southern Ethiopia. The Geographical Journal, 177(1), pp.62-78.

Tilahun, M., Angassa, A. and Abebe, A., 2017. Community-based knowledge towards rangeland condition, climate change, and adaptation strategies: the case of Afar pastoralists. Ecological Processes, 6(1), pp.113.

Toulmin, C., 2009. Securing land and property rights in sub-Saharan Africa: the role of local institutions. Land use policy, 26(1), pp.10-19. 
Tryland, M., Stubsjøen, S.M., Ågren, E., Johansen, B. and Kielland, C., 2015. Herding conditions related to infectious keratoconjunctivitis in semi-domesticated reindeer: a questionnaire-based survey among reindeer herders. Acta Veterinaria Scandinavica, 58(1), pp.1-10.

Turner, M.D. and Hiernaux, P., 2002. The use of herders' accounts to map livestock activities across agropastoral landscapes in Semi-Arid Africa. Landscape Ecology, 17(5), pp.367-385.

Turunen, M., Vuojala-Magga, T. and Giguère, N., 2014. Past and present winter feeding of reindeer in Finland: herders' adaptive learning of feeding practices. Arctic, pp.173-188.

Turunen, M.T., Rasmus, S., Bavay, M., Ruosteenoja, K. and Heiskanen, J., 2016. Coping with difficult weather and snow conditions: Reindeer herders' views on climate change impacts and coping strategies. Climate Risk Management, 11, pp.15-36.

Tyiso, S. and Bhat, R.B., 1998. Medicinal plants used for child welfare in the Transkei region of the Eastern Cape (South Africa). Angewandte Botanik, 72(3-4), pp.92-98.

Tyler, N.J.C., Turi, J.M., Sundset, M.A., Bull, K.S., Sara, M.N., Reinert, E., Oskal, N., Nellemann, C., McCarthy, J.J., Mathiesen, S.D. and Martello, M.L., 2007. Saami reindeer pastoralism under climate change: applying a generalized framework for vulnerability studies to a sub-arctic social-ecological system. Global Environmental Change, 17(2), pp.191-206.

Uprety, Y., Poudel, R.C., Shrestha, K.K., Rajbhandary, S., Tiwari, N.N., Shrestha, U.B. and Asselin, H., 2012. Diversity of use and local knowledge of wild edible plant resources in Nepal. Journal of Ethnobiology and Ethnomedicine, 8(1), pp.1-15.

Usman, I.S., Bzugu, P.M., Pur, J.T. and Abdullahi, A., 2017. Indigenous Control Methods for Parasites among Pastoralists Communities in Adamawa State, Nigeria. Journal of Agricultural Extension, 21(1), pp.109-121.

Usman, L.M., 2010. The indigenous knowledge system of female pastoral Fulani of Northern Nigeria. In Indigenous Knowledge and Learning in Asia/Pacific and Africa (pp. 213-225). Palgrave Macmillan, New York.

Van Veen, T.S., 1997. Sense or nonsense? Traditional methods of animal parasitic disease control. Veterinary parasitology, 71(2-3), pp.177-194.

Varga, A., Molnár, Z., Biró, M., Demeter, L., Gellény, K., Miókovics, E., Molnár, Á., Molnár, K., Ujházy, N., Ulicsni, V. and Babai, D., 2016. Changing year-round habitat use of extensively grazing cattle, sheep and pigs in East-Central Europe between 1940 and 2014: Consequences for conservation and policy. Agriculture, Ecosystems \& Environment, 234, pp.142-153.

Verlinden, A. and Kruger, A.S., 2007. Changing grazing systems in central north Namibia. Land Degradation \& Development, 18(2), pp.179-197.

Verlinden, A., Seely, M.K. and Hillyer, A., 2006. Settlement, trees and termites in Central North Namibia: a case of indigenous resource management. Journal of arid environments, 66(2), pp.307-335.

Vilches, F. and Morales, H., 2017. From herders to wage laborers and back again: engaging with capitalism in the Atacama Puna Region of Northern Chile. International Journal of Historical Archaeology, 21(2), pp.369-388.

Volpato, G., Di Nardo, A., Rossi, D., Saleh, S.M.L. and Broglia, A., 2013. 'Everybody knows', but the rest of the world: the case of a caterpillar-borne reproductive loss syndrome in dromedary camels observed by Sahrawi pastoralists of Western Sahara. Journal of ethnobiology and ethnomedicine, 9(1), pp.1-11.

Volpato, G., Saleh, S.M.L. and Di Nardo, A., 2015. Ethnoveterinary of Sahrawi pastoralists of Western Sahara: camel diseases and remedies. Journal of ethnobiology and ethnomedicine, 11(1), pp.1-22. 
Vors, L.S. and Boyce, M.S., 2009. Global declines of caribou and reindeer. Global change biology, 15(11), pp.2626-2633.

Vuojala-Magga, T. and Turunen, M.T., 2015. Sámi reindeer herders' perspective on herbivory of subarctic mountain birch forests by geometrid moths and reindeer: a case study from northernmost Finland. SpringerPlus, 4(1), pp.1-13.

Vuojala-Magga, T., Turunen, M., Ryyppo, T. and Tennberg, M., 2011. Resonance strategies of Sámi reindeer herders in northernmost Finland during climatically extreme years. Arctic, pp.227-241.

Wako, D.D., Younan, M., Tessema, T.S., Glücks, I.V. and Baumann, M.P.O., 2016. Indigenous knowledge of pastoralists on respiratory diseases of camels in northern Kenya. Preventive veterinary medicine, 130, pp.60-66.

Wang, Y., Sun, Y., Wang, Z., Chang, S. and Hou, F., 2018. Grazing management options for restoration of alpine grasslands on the Qinghai-Tibet Plateau. Ecosphere, 9(11), p.e02515.

Wanzala, W., Takken, W., Mukabana, W.R., Pala, A.O. and Hassanali, A., 2012. Ethnoknowledge of Bukusu community on livestock tick prevention and control in Bungoma district, western Kenya. Journal of Ethnopharmacology, 140(2), pp.298-324.

Warkineh, T.Z. and Gizaw, A.M., 2019. Exploring the informal learning experiences of women in a pastoral community in Ethiopia: The case of pastoral women in Karrayyu. Studies in the Education of Adults, 51(2), pp.250-267.

Waters-Bayer, A. 2017. "The future of pastoralism/L'avenir du pastoralisme/El futuro del pastoreo.": 303306.

Watkins, B. and Fleisher, M.L., 2002. Tracking pastoralist migration: lessons from the Ethiopian Somali national regional state. Human organization, pp.328-338.

Waudby, H.P., Petit, S. and Robinson, G., 2012. Pastoralists' perceptions of biodiversity and land management strategies in the arid Stony Plains region of South Australia: Implications for policy makers. Journal of Environmental Management, 112, pp.96-103.

Waudby, H.P., Petit, S. and Robinson, G., 2013. Pastoralists' knowledge of plant palatability and grazing indicators in an arid region of South Australia. The Rangeland Journal, 35(4), pp.445-454.

Ween, G.B. and Riseth, J.Å., 2011. Doing is learning: analysis of an unsuccessful attempt to adapt TEK/IK methodology to Norwegian Sámi circumstances. Acta Borealia, 28(2), pp.228-242.

Williams, D.M., 2000. Representations of nature on the Mongolian steppe: An investigation of scientific knowledge construction. American Anthropologist, 102(3), pp.503-519.

Witte, F., Wanink, J.H. and Kishe-Machumu, M., 2007. Species distinction and the biodiversity crisis in Lake Victoria. Transactions of the American Fisheries Society, 136(4), pp.1146-1159.

Wu, N., Ismail, M., Joshi, S., Yi, S.L., Shrestha, R.M. and Jasra, A.W., 2014. Livelihood diversification as an adaptation approach to change in the pastoral Hindu-Kush Himalayan region. Journal of Mountain Science, 11(5), pp.1342-1355.

Wu, X., Zhang, X., Dong, S., Cai, H., Zhao, T., Yang, W., Jiang, R., Shi, Y. and Shao, J., 2015. Local perceptions of rangeland degradation and climate change in the pastoral society of Qinghai-Tibetan Plateau. The Rangeland Journal, 37(1), pp.11-19.

Wurchaih, H. and Menggenqiqig, K., 2019. Medicinal wild plants used by the Mongol herdsmen in Bairin Area of Inner Mongolia and its comparative study between TMM and TCM. Journal of Ethnobiology and Ethnomedicine, 15. 
Wurzinger, M., Ndumu, D., Baumung, R., Drucker, A., Okeyo, A.M., Semambo, D.K., Byamungu, N. and Sölkner, J., 2006. Comparison of production systems and selection criteria of Ankole cattle by breeders in Burundi, Rwanda, Tanzania and Uganda. Tropical Animal Health and Production, 38(7), pp.571-581.

Wurzinger, M., Ndumu, D., Okeyo, A.M. and Souml, J., 2008. Lifestyle and herding practices of Bahima pastoralists in Uganda. African Journal of Agricultural Research, 3(8), pp.542-548.

Yacoub, H., 2018. Knowledge and community resilience in rangelands recovery: the case of Wadi Allaqi Biosphere Reserve, South Eastern Desert, Egypt. Restoration Ecology, 26, pp.S37-S43.

Yager, K., Valdivia, C., Slayback, D., Jimenez, E., Meneses, R.I., Palabral, A., Bracho, M., Romero, D., Hubbard, A., Pacheco, P. and Calle, A., 2019. Socio-ecological dimensions of Andean pastoral landscape change: bridging traditional ecological knowledge and satellite image analysis in Sajama National Park, Bolivia. Regional Environmental Change, 19(5), pp.1353-1369.

Yates, J.S., 2014. Historicizing 'ethnodevelopment': Kamayoq and political-economic integration across governance regimes in the Peruvian Andes. Journal of Historical Geography, 46, pp.53-65.

Zalatan, R., Gunn, A. and Henry, G.H.R., 2006. Long-term abundance patterns of barren-ground caribou using trampling scars on roots of Picea mariana in the Northwest Territories, Canada. Arctic, Antarctic, and Alpine Research, 38(4), pp.624-630.

Zampaligré, N., Dossa, L.H. and Schlecht, E., 2014. Climate change and variability: perception and adaptation strategies of pastoralists and agro-pastoralists across different zones of Burkina Faso. Regional Environmental Change, 14(2), pp.769-783.

Zhang, C., Li, W. and Fan, M., 2013. Adaptation of herders to droughts and privatization of rangeland-use rights in the arid Alxa Left Banner of Inner Mongolia. Journal of environmental management, 126, pp.182-190.

Zurayk, R., el-Awar, F., Hamadeh, S., Talhouk, S., Sayegh, C., Chehab, A.G. and al Shab, K., 2001. Using indigenous knowledge in land use investigations: a participatory study in a semi-arid mountainous region of Lebanon. Agriculture, ecosystems \& environment, 86(3), pp.247-262. 